UNIVERSIDADE DE SÃO PAULO

INSTITUTO DE BIOCIÊNCIAS

FELIPE RAMON PODADERA DE CHIARA

Diversidade dos silídeos (Annelida: Phyllodocida: Syllidae) associados ao fital no litoral de São Sebastião - SP

Diversity of Syllidae (Annelida: Phyllodocida) associated to the fital in São Sebastião coast - SP

São Paulo 
FELIPE RAMON PODADERA DE CHIARA

\title{
Diversidade dos silídeos (Annelida: Phyllodocida: Syllidae) associados ao fital no litoral de São Sebastião - SP
}

\author{
Versão Original
}

Trabalho apresentado ao Instituto de Biociências da Universidade de São Paulo, para obtenção do título de Mestre em Ciências Biológicas, na área de Zoologia.

Orientador: Prof. Dr. João Miguel de Matos Nogueira

São Paulo 
De Chiara, Felipe Ramon Podadera

Diversidade dos silídeos (Annelida: Phyllodocida: Syllidae) associados ao fital no litoral de São Sebastião - SP

115 páginas

Dissertação (Mestrado) - Instituto de Biociências da Universidade de São Paulo. Departamento de Zoologia.

1. Polychaeta 2. Taxonomia 3. Morfologia. Universidade de São Paulo. Instituto de Biociências. Departamento de Zoologia.

\section{Comissão Julgadora}

Prof(a). Dr(a)

$\operatorname{Prof}(\mathrm{a}) . \operatorname{Dr}(\mathrm{a})$

Prof. Dr. João Miguel de Matos Nogueira

Orientador 


\section{AGRADECIMENTOS}

Ao Prof. Dr. João Miguel de Matos Nogueira, por me ajudar a descobrir tanto sobre os Polychaeta, por todos os cafés e boas risadas, e por ser mais que um grande orientador, mas também um grande amigo;

À Capes, pela bolsa de mestrado concedida durante o período de elaboração e realização do projeto;

Ao Prof. Dr. Marcelo Veronesi Fukuda, que me acolheu na família Syllidae e sempre me ajudou a identificá-los, por menor e mais destruídos que estivessem. Por toda a calma e paciência para me explicar sobre o assunto e pela coorientação dada desde o primeiro dia que eu estive no laboratório, bem como pela amizade que essa relação trouxe;

Aos amigos Ênio Matos e Philip Lenktaitis, que desde a minha graduação tornam a sala de MEV um ambiente menos cansativo, por todos os papos e risadas tidas esperando as fotos, ou o vácuo, estarem prontos;

Aos amigos do LaPol, Orlemir, Karla, Carlos, Gilberto e Rafael, que sempre estiveram lá por mim quando eu precisei, por mais simples que fosse a dúvida, e sempre estiveram lá para dividir boas risadas;

Aos meus pais, Paulo e Jussara, e ao meu irmão, Alexandre, que me orientam desde que abri os olhos. Por me tornarem o homem que sou hoje e dividirem cada pequena alegria que tenho na vida como se fosse um marco. Por serem grande parte daquilo que a vida tem de bom;

À minha tia Águeda De Chiara, que me alfabetizou, sendo minha primeira professora, e iniciando essa fome por conhecimento;

À Sarah, que me mostrou as cores e as verdadeiras prioridades da vida. Por ser meu apoio nos momentos ruins, e bons, e por me mostrar o verdadeiro companheirismo. A eternidade não seria suficiente para agradecer por tudo que você me ensina todos os dias e por todo amor que você me oferece; 
A todos os amigos e familiares que estiveram do meu lado nessa trajetória, e que se contentavam com a explicação de que poliquetas são "minhocas do mar" e que mostraram interesse no assunto, apesar de ficar claro de que não faziam ideia do que eu estava falando.

Meu muito obrigado a todos! 


\section{ÍNDICE}

Resumo

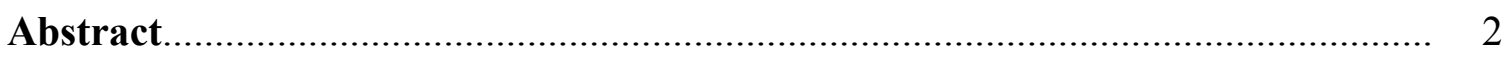

I - Introdução .....................................................................................

II - Objetivos Gerais.................................................................................... 6

III - Materiais e Métodos....................................................................................... 6

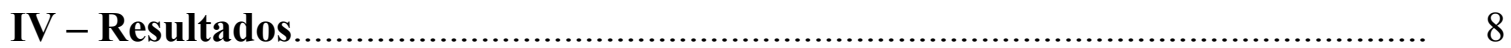

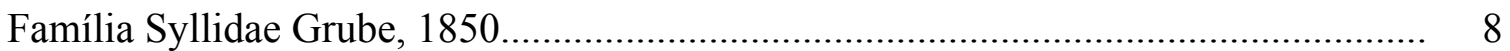

Chave de identificação para as subfamílias da família Syllidae encontradas neste

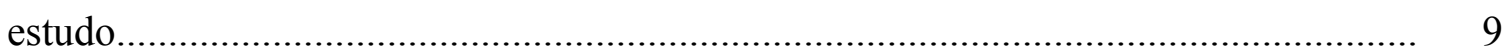

Subfamília Autolytinae Langerhans, 1879.............................................................. $\quad 10$

Chave de identificação para as espécies de Autolytinae encontradas neste

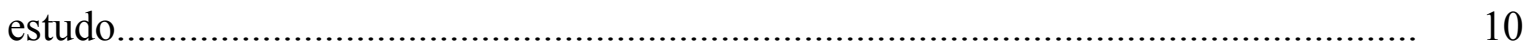

Gênero Myrianida Milne-Edwards, 1845 .............................................................. 10

Myrianida prolifera (O.F. Müller, 1788) ...................................................... 11

Gênero Proceraea Ehlers, 1864................................................................................ 13

Proceraea hanssoni Nygren, 2004............................................................ 14

Subfamília Eusyllinae Malaquin, 1893 ................................................................... 16

Chave de identificação para os gêneros de Eusyllinae encontrados neste

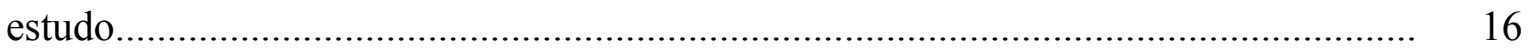

Gênero Eusyllis Malmgren, 1867............................................................................ 16

Chave de identificação para as espécies de Eusyllis encontradas neste

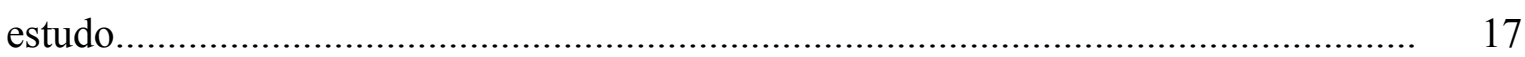

Eusyllis assimilis Marenzeller, 1875............................................................. 17

Eusyllis kupfferi Langerhans, 1879............................................................ 19

Gênero Odontosyllis Claparède, 1863......................................................................... 21

Chave de identificação para as espécies de Odontosyllis encontradas neste estudo.

Odontosyllis cf. fulgurans (Audouin \& Milne, 1833).................................... 22

Odontosyllis guillermoi Fukuda \& Nogueira, 2006........................................ 24

Odontosyllis sp. 1 sp. nov. ....................................................................... 26

Gênero Perkinsyllis San Martín, López \& Aguado, 2009........................................... 30 
Chave de identificação para as espécies de Perkinsyllis encontradas neste estudo.

Perkinsyllis biota Fukuda \& Nogueira, 2013 .............................................. $\quad 30$

Perkinsyllis koolalya (San Martín \& Hutchings, 2006)................................ 33

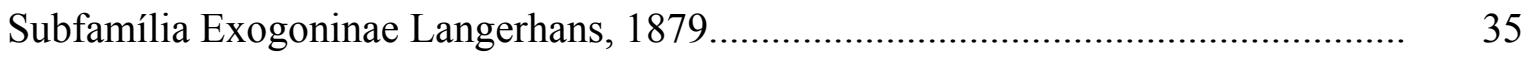

Chave de identificação para os gêneros de Exogoninae encontrados neste

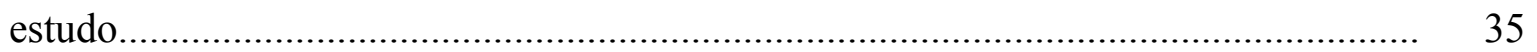

Gênero Erinaceusyllis San Martín, 2005................................................................. 36

Chave de identificação para as espécies de Erinaceusyllis encontradas neste

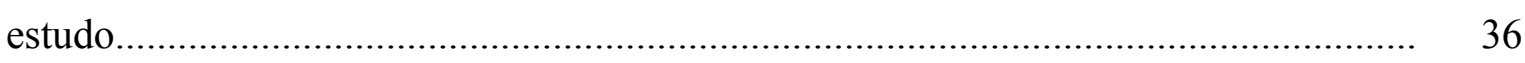

Erinaceusyllis bilobata (Perkins, 1981) ................................................... 37

Erinaceusyllis perkinsi (Riser, 1991) .......................................................... 39

Erinaceusyllis sp. 1 sp. nov. ..................................................................... 40

Gênero Exogone Örsted, 1845............................................................................. 42

Chave de identificação para as espécies de Exogone encontradas neste estudo.

Exogone (Exogone) africana Hartmann-Schröder, 1974............................... 44

Exogone (Exogone) breviantennata Hartmann-Schröder, 1959.............. 46

Exogone (Exogone) lourei Berkeley \& Berkeley, 1938................... 47

Gênero Sphaerosyllis Claparède, 1863.................................................................... 49

Sphaerosyllis densopapillata Hartmann-Schröder, 1979............................. 50

Subfamília Syllinae Rioja, 1925 ........................................................................ 52

Chave de identificação para os gêneros de Syllinae encontrados neste

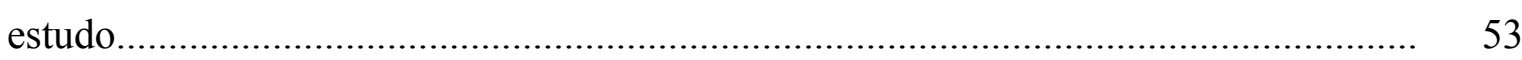

Gênero Branchiosyllis Ehlers, 1887.................................................................... $\quad 54$

Branchiosyllis exilis (Gravier, 1900) .......................................................... 54

Gênero Haplosyllis Langerhans, 1879..................................................................... 57

Chave de identificação para as espécies de Haplosyllis neste estudo........................... 57

Haplosyllis amphimedonicola Paresque \& Nogueira, 2014........................... 57

Haplosyllis rosenalessoae Paresque \& Nogueira, 2014................................... 59

Gênero Megasyllis San Martín, Hutchings \& Aguado, 2008...................................... 61

Chave de identificação para as espécies de Megasyllis encontradas neste

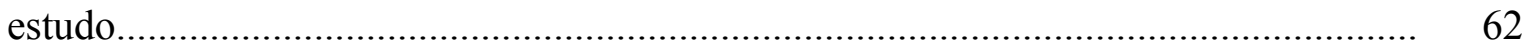

Megasyllis procera (Hartman, 1965) ............................................................. 62 
Megasyllis sp. 1 sp. nov. ........................................................................ 64

Gênero Opisthosyllis Langerhans, 1879................................................................ 67

Opisthosyllis brunnea Langerhans, 1879 ................................................... 68

Gênero Syllis Lamarck, 1818........................................................................... 70

Chave de identificação para as espécies de Syllis encontradas neste

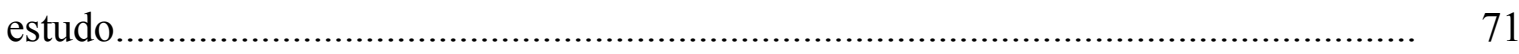

Syllis corallicola Verrill, 1900...................................................................... 72

Syllis hyllebergi (Licher, 1999) ................................................................ 74

Syllis lutea (Hartmann-Schöder, 1960) ......................................................... 77

Syllis prolifera Krohn, 1852 .................................................................... 79

Syllis pseudoarmillaris Nogueira \& San Martín, 2002...................... 81

Syllis rosea (Langerhans, 1879.................................................................. 83

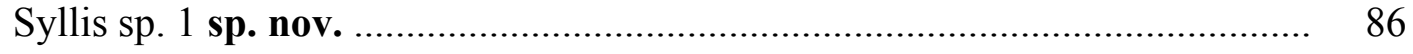

Syllis truncata Haswell, 1920 ........................................................................ 89

Syllis westheidei San Martín, 1984.............................................................. 91

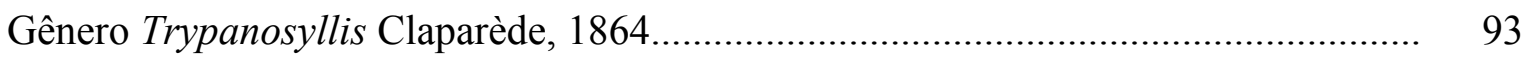

Trypanosyllis zebra (Grube, 1860) ........................................................... 94

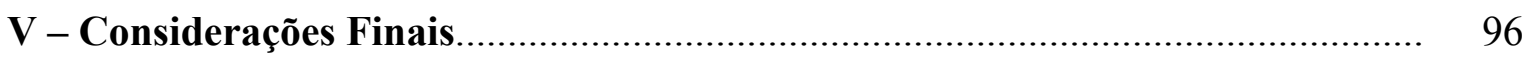

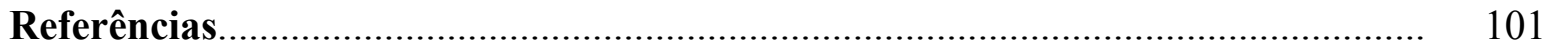




\section{RESUMO}

DE CHIARA, Felipe Ramon Podadera. Diversidade dos silídeos (Annelida: Phyllodocida: Syllidae) associados ao fital no litoral de São Sebastião - SP. 2017. 115 f. Dissertação (Mestrado em Zoologia) - Instituto de Biociências, Universidade de São Paulo, São Paulo, 2017.

A família Syllidae, apesar de ser uma das mais diversas e abundantes dentre os poliquetas, possui apenas cerca de 140 espécies registradas no litoral brasileiro, o que é pouco, considerando-se a extensão da nossa costa e o número de espécies encontradas em locais onde a família já foi melhor analisada. O presente estudo tem como objetivo analisar taxonomicamente os silídeos de um ambiente em que foram pouco estudados no Brasil, até o momento, o fital. A área de estudo foi composta por algumas praias de São Sebastião, litoral norte de São Paulo. Além da caracterização taxonômica das espécies encontradas, foram identificados padrões de associações específicas entre determinadas espécies de algas e alguns silídeos, algumas dessas relações já conhecidas em certas localidades, mas poucas vezes relatadas para o Brasil. Foram encontradas 1 nova ocorrência para a costa brasileira, e 4 espécies novas para a ciência. 


\section{ABSTRACT}

DE CHIARA, Felipe Ramon Podadera. Diversidade dos silídeos (Annelida: Phyllodocida: Syllidae) associados ao fital no litoral de São Sebastião - SP. 2017. 115 f. Dissertação (Mestrado em Zoologia) - Instituto de Biociências, Universidade de São Paulo, São Paulo, 2017.

The family Syllidae, in spite of being among the most diverse and abundant groups of polychaetes, has only about 140 species registered for off the Brazilian coast, which is a low number, considering the extension of our coast and the number of species found in places where the syllids have been more thoroughly analyzed. The present study is a taxonomic survey on the syllids occurring on an environment which has been rarely studied in Brazil so far, the phytal. The study was carried out off some beaches off São Sebastião, on the northern coast of the state of São Paulo. In addition to the characterization of the species found, some patterns of specific associations between certain species of algae and some syllids have been observed, some of those relationships are already known for certain localities around the world, but were rarely reported for the Brazilian coast. Among all the species analyzed, one new occurrence off the Brazilian coast and four species new to science were found. 


\section{I - INTRODUÇÃO}

Os poliquetas são um grupo de animais em sua maioria marinhos, comumente divididos em errantes e sedentários, grupos esses determinados pelo hábito comportamental predominante, embora ainda haja muito debate se esses grupos têm valor sistemático, ou se as adaptações morfológicas se tratam de convergências, em virtude de especializações independentes para um cada hábito de vida (ROUSE \& FAUCHALD, 1997). Poliquetas errantes são aqueles que apresentam estruturas especializadas para locomoção, bem como órgãos sensoriais bem desenvolvidos, frequentemente apresentando uma cabeça diferenciada. Dentre estes, encontramos tanto espécies planctônicas ou pelágicas, adaptadas para a natação, quanto bentônicas, sejam aquelas que se locomovem sobre o substrato ou as que formam tubos e vivem de tocaia dentro dos mesmos, esperando pela passagem de presas, mas apresentando corpo com a morfologia típica de errantes e frequentemente saindo de seus tubos, apresentando comportamento vágil. Poliquetas sedentários são aqueles cujas larvas produzem um tubo dentro do qual estes animais se alojam pela vida toda; em alguns casos, eles podem abandonar seus tubos sob condições desfavoráveis, em busca de ambientes mais propícios, mas em diversas famílias os indivíduos adultos são incapazes de formar novos tubos se desalojados, estando permanentemente presos ao local de fixação das larvas.

Com aproximadamente 80 famílias e 16000 espécies (ROUSE \& PLEIJEL, 2001; BRUSCA et al., 2016), os poliquetas compõem um grupo cosmopolita, com ampla distribuição, encontrados em qualquer ambiente marinho, desde a zona entremarés a grandes profundidades, além de ser frequentemente o táxon dominante em riqueza e abundância no ambiente (HUTCHINGS, 1998). Uma grande porcentagem das espécies de poliquetas ainda não foi identificada em diversas regiões do mundo, entre elas o litoral da América do Sul (SNELGROVE et al., 1997), tendo sido registrada no Brasil, até 
o momento, a presença de 68 famílias, com 1149 espécies (AMARAL et al., 2013).

Os Syllidae Grube, 1850, são poliquetas relativamente pequenos, geralmente apresentando de poucos milímetros a alguns centímetros de comprimento. Trata-se de um grupo de fácil reconhecimento graças à presença do proventrículo, estrutura associada à faringe e facilmente visualizável pelo corpo translúcido, contudo, a identificação aos níveis genérico e, principalmente, específico, é considerada difícil (ROUSE \& PLEIJEL, 2001). Apesar de abundantes na maioria das amostras marinhas coletadas, ainda são raros os exemplares de silídeos provenientes de campanhas em grande profundidade (SAN MARTÍN, 2003, 2004). Geralmente o prostômio de silídeos apresenta dois pares de olhos, podendo haver também um par de manchas ocelares, três antenas, uma central e duas laterais, e um par de palpos inseridos ventralmente e de aspecto triangular, cujo grau de fusão é diagnóstico para a diferenciação das subfamílias.

Atualmente, Syllidae é dividida em cinco subfamílias: Anoplosyllinae Aguado e San Martín, 2009; Autolytinae Langerhans, 1879; Exogoninae Langerhans, 1879; Eusyllinae Malaquin, 1893; e Syllinae Grube, 1850, além de alguns gêneros que não foram alocados em nenhuma dessas subfamílias e têm sido tratados recentemente como incertae sedis (AGUADO et al., 2012).

No Brasil, até o momento é conhecida a presença de cerca de 140 espécies de silídeos (AMARAL et al., 2013; PARESQUE et al., 2014), o que é pouco, em se considerando a extensão da costa brasileira e o número de espécies da família registradas em locais onde a fauna é melhor conhecida, como na Península Ibérica e Austrália (SAN MARTÍN, 2003; SAN MARTÍN et al., 2008a, b, 2010). A maioria dos registros refere-se a material da zona costeira, da região entremarés a profundidades relativamente baixas, contudo, os estudos em ambientes distintos desses tem aumentado exponencialmente. 
O Laboratório de Poliquetologia do IB-USP (LaPol), assim como trabalhos de membros do mesmo anteriores à sua criação, foi pioneiro no estudo taxonômico aprofundado da família Syllidae no Brasil (NOGUEIRA, 2000; FUKUDA, 2010; PARESQUE, 2014) e continua sendo um dos poucos laboratórios trabalhando com essa família no país. Nogueira (2000) verificou a presença de 41 espécies associadas ao coral Mussismilia hispida, Fukuda (2010) encontrou 24 gêneros e 83 espécies de silídeos em diversos ambientes do litoral de São Paulo, da zona entremarés a cerca de $800 \mathrm{~m}$ de profundidade, enquanto Paresque (2014) identificou 20 gêneros e 57 espécies na zona entremarés e ambientes superficiais (mergulho livre) de recifes de arenito do litoral da Paraíba e Pernambuco.

Contudo, esses estudos analisaram principalmente material coletado em costões rochosos ou recifes de arenito e, embora as algas encontradas nestes locais tenham sido razoavelmente bem amostradas, a fauna do fital propriamente dita não foi foco dos mesmos (FUKUDA, 2010; PARESQUE, 2014).

O fital é um ecossistema marinho formado por macroalgas e complexa comunidade bentônica associada (MASUNARI \& FORNENIS, 1981; MASUNARI, 1987). Dentre a fauna encontrada no sudeste do Brasil, um dos grupos com maior abundância e riqueza de espécies é o dos poliquetas (NASCIMENTO \& ROSSO, 2007), entretanto a quantidade de espécies registradas para o fital é baixa, o que pode ser devido às metodologias adotadas, geralmente apropriadas para o estudo de animais de maior porte. Deve-se destacar que os silídeos são reconhecidamente caracterizados pela sua ocorrência nos mais variados habitats, sendo comuns associações simbiontes tanto com outros animais (MARTIN \& BRITAYEV, 1998), quanto com algas (MARTIN, 1987).

O presente trabalho foi conduzido em São Sebastião, município onde foi verificada a ocorrência de quase todas as espécies registradas no litoral de São Paulo (FUKUDA, 2010). O ambiente marinho e, particularmente, o fital, são 
propícios para a ocorrência de espécies crípticas (BICKFORD et al., 2007), e já foi verificado que estas ocorrem dentre todos os grandes grupos taxonômicos animais (KNOWLTON, 1993, 2000), não sendo os poliquetas uma exceção. Entende-se por espécies crípticas casos em que se verifica como pertencentes a espécies diferentes animais de dois (ou mais) táxons morfologicamente muito similares ou mesmo indistinguíveis, cuja separação só é possível através da utilização de ferramentas moleculares (DNA). Também é possível indicar a existência de espécies crípticas através de estudos morfométricos, contudo, nesse caso, elas são melhor denominadas pseudocrípticas (SÁEZ \& LOZANO, 2005; NYGREN, 2013), já que a separação se baseia em um refinamento da análise morfológica, sendo aconselhável, também, a utilização de outras classes de dados para corroborar a separação, como os estudos moleculares.

\section{II - OBJETIVOS GERAIS}

Este estudo tem como objetivo analisar a diversidade das espécies de silídeos presentes no fital de São Sebastião, litoral norte de São Paulo, fornecendo descrições completas dos táxons encontrados, bem como pranchas diagnósticas para os mesmos, contribuindo para um melhor conhecimento da biodiversidade marinha brasileira.

Um dos objetivos do trabalho era manter cada ambiente (espécie de alga) isolado dos demais, com intuito de poder averiguar qual espécie estava associada com qual ambiente. Também se teve o cuidado de fazer coltadas em duas estações do ano distintas nas mesmas localidades, a fim de evidenciar qualquer diferença. Outro objetivo deste estudo era realizar medições morfométricas dos indivíduos das espécies encontradas.

Com esses dados em mãos, são possíveis estudos mais aprofundados sobre o grupo, que visem analizar as relações que podemos traçar entre os indíviduos e os ambientes que habitam. 


\section{III - MATERIAIS E MÉTODOS}

Este projeto analisou e identificou os silídeos coletados no fital de São Sebastião, no litoral de São Paulo. A delimitação da área de estudo ao município de São Sebastião justifica-se tanto pela maior facilidade de trabalho na região, dado o apoio fornecido pelo Centro de Biologia Marinha da USP (CEBIMar), quanto por projetos anteriores conduzidos pelo LaPol terem verificado que no município ocorre a grande maioria das espécies de poliquetas encontradas ao longo de todo o Estado de São Paulo.

Foram coletados talos pertencentes as seguintes espécies de algas: Caulerpa lentilifera, Dyctiota ciliolata, Gracilaria sp., Hypnea musciform e Sargassum sp., sendo estas coletadas na zona entre-marés, ao longo dos mais de $100 \mathrm{~km}$ de praias do município. O material coletado foi mantido em aquários com água do mar corrente, para que os animais fossem selecionados vivos. Os talos foram examinados sob microscópio estereoscópico, os poliquetas extraídos, anestesiados em solução de mentol e preservados em solução de formalina a 4\%. Embora fora do escopo do presente projeto, parte do material foi preservada diretamente em álcool absoluto, visando futuros estudos moleculares (ver abaixo). Os exemplares encontrados de outras famílias de poliquetas também foram preservados, bem como material de outros filos animais, dependendo da disponibilidade de pessoas para auxiliar na triagem.

Os silídeos foram identificados ao nível de espécie ou, dependendo de seu estado de preservação, ao nível taxonômico menos inclusivo possível. Estas identificações foram feitas exclusivamente por caracteres morfológicos, com o acompanhamento de bibliografia especializada. Os animais foram examinados sob microscópios estereoscópico, óptico e eletrônico de varredura, este último de acordo com a disponibilidade de exemplares de cada espécie e do estado de preservação dos mesmos, e fotografados sob os dois últimos. 
Para a observação ao microscópio óptico, foram montados animais inteiros, representantes de todas as espécies, em lâminas permanentes em Aquatex ${ }^{\circledR}$. Este meio confere certo grau de diafanização de tecidos, possibilitando a observação de detalhes de morfologia interna e de cerdas. Para a observação ao microscópio eletrônico de varredura, o material foi inicialmente desidratado em baterias de solução de etanol com concentrações progressivamente maiores, entre $70-100 \%$, e, em seguida, através do equipamento de Ponto Crítico; os animais foram então colocados nos stubs, cobertos com uma fina camada de ouro de $30-25 \mathrm{~nm}$ e estudados sob o feixe de elétrons.

As medidas dos animais foram tomadas segundo a seguinte metodologia:

- comprimento: da extremidade do prostômio à extremidade do pigídio, excluindo os palpos e os cirros anais;

- largura: medida na altura do proventrículo, excluindo os parapódios;

- comprimento das lâminas das cerdas: da ponta do dente distal à base da lâmina, as medidas são fornecidas em ordem dorso-ventral, em cada parapódio.

Foi feito extenso levantamento morfométrico sob microscópio óptico de exemplares de algumas das espécies encontradas, particularmente daquelas com ampla ocorrência no litoral brasileiro, e os dados foram comparados com aqueles de populações das mesmas espécies, ocorrendo em outros ambientes de São Paulo e no nordeste do Brasil, obtidos em projetos anteriores conduzidos pelo LaPol (FUKUDA, 2010; PARESQUE, 2014). Pretendia-se, com isso, investigar a possível presença de espécies pseudocrípticas, merecedoras de futuros estudos moleculares mais aprofundados.

O presente projeto utilizou exclusivamente dados morfológicos para a identificação dos silídeos, pois consideramos que o prazo do curso de Mestrado não permite que incluamos também análises moleculares, em se considerando o volume de trabalho que a parte morfológica demanda para os presentes 
objetivos. Entretanto, parte do material coletado foi fixada diretamente em álcool absoluto visando uma continuidade do estudo em nível molecular, que poderá ser feita futuramente pelo próprio aluno, ou colegas de laboratório.

Ao final do projeto, as descrições das espécies serão submetidas para publicação em periódicos de impacto na área, formalizando a descrição dos táxons encontrados (ICZN, 1999) e o registro dos mesmos. O material será depositado no Museu de Zoologia da Universidade de São Paulo (MZUSP), no Museu de Zoologia da Universidade Estadual de Campinas (ZUEC) e, quando o número amostral for suficiente, exemplares-tipo poderão vir a ser depositados também em museus estrangeiros.

\section{IV - RESULTADOS}

Foram analisados 517 espécimes, pertencentes a 4 subfamílias, 15 gêneros e 32 espécies de Syllidae. Destes, um registro é uma nova ocorrência da espécie para a costa brasileira, e quatro espécies são novas para a ciência.

\section{Família Syllidae Grube, 1850}

Diagnose: animais de tamanho corpóreo pequeno a médio, geralmente com menos de $5 \mathrm{~cm}$ de comprimento, com corpo subcilíndrico a achatado dorsoventralmente e, salvo exceções, com número de segmentos variável. Prostômio com um par de palpos, de formato e grau de fusão entre os mesmos variáveis, 12 pares de olhos, frequentemente também com 1 par de manchas ocelares anteriores, e 3 antenas. Peristômio com 1-2 pares de cirros peristomiais e boca ventral. Parapódios unirremes, cirros dorsais e ventrais normalmente conspícuos, cerdas simples dorsal e ventral, cerdas compostas falcígeras, pseudoespinígeras e cerdas secundariamente simples por perda da lâmina, ou fusão da mesma com a haste, podem estar presentes. Farínge eversível, 
geralmente com 1 dente e/ou trépano, seguida por proventrículo com fileiras musculares transversais.

Comentários: indivíduos dessa família podem ser facilmente identificados pela presença do proventrículo, visível por transparência, através da superfície do corpo. A morfologia dos palpos e dos cirros dorsais e ventrais são as principais características que definem as subfamílias conhecidas.

\section{Chave de identificação para as subfamílias da família Syllidae encontradas neste estudo}

1a. Faringe convoluta, no mínimo uma sinuosidade; cirros ventrais ausentes ou incospícuos, fundidos aos lobos parapodiais Autolytinae

1b. Faringe reta; cirros ventrais conspícuos .2

2a.(1b) Palpos fundidos em sua totalidade, ou livres apenas na extremidade distal. Exogoninae

2b. Palpos livres, no mínimo, em toda a metade distal 3

3a.(2b) Cirros dorsais articulados, embora haja táxons com um único artículo por cirro dorsal Syllinae

3b. Cirros dorsais lisos ou pseudo-articulados Eusyllinae

\section{Subfamília Autolytinae Langerhans, 1879}

Diagnose: animais de tamanho corpóreo pequeno a médio, corpo subcilíndrico. Palpos virados em direção ventral, ocultos pelo prostômio em vista dorsal. Antenas, cirros peristomiais e dorsais comumente presentes, com cirróforo basal e cirróstilo distal; cirros ventrais inconspícuos, fundidos aos lobos parapodiais 
ou ausentes. Cerdas falcígeras bidentadas, dente subdistal maior, e cerdas simples dorsais em baioneta; cerdas pseudoespinígeras podem também estar presentes. Faringe com no mínimo uma circumvolução e, frequentemente, trépano na extremidade anterior.

Comentários: muitas das identificações das espécies de Autolytinae se baseiam na coloração de animais vivos, difícultando ou inviabilizando a identificação após a preservação dos exemplares (NYGREN, 2004).

\section{Chave de identificação para as espécies de Autolytinae encontradas neste estudo}

- Trépano com mais de 20 dentes pequenos, geralmente com maior número de dentes na metade dorsal (20-16 x 14-10, no lado ventral). Pigmentação ausente ou inconspícua Myrianida. M. prolifera

- Trépano com menos de 20 dentes relativamente grandes, dos quais 9-10 na metade dorsal e 10-8 na ventral. Pigmentação característica, possuindo uma faixa transversal escura na região anterior de cada setígero.

Proceraea. P. hanssoni

\section{Gênero Myrianida Milne-Edwards, 1845}

Espécie-tipo: Nereis pinnigera Montagu, 1808.

Diagnose: prostômio ovalado, com 2 pares de olhos em trapézio, o anterior ligeiramente maior. Palpos fundidos pelo menos em metade de seu comprimento, rebatidos ventralmente, e 3 antenas, as laterais inseridas na margem anterior do prostômio, a mediana próximo à linha dos olhos anteriores. Corpo subcilíndrico. Antenas com ceratóforo e ceratóstilo, e cirros peristomiais 
e dorsais ao longo do corpo de morfologia semelhante, com cirróforo basal e cirróstilo distal. Cerdas falcígeras bidentadas, com dente subdistal maior, cerdas simples dorsais em baioneta, espinuladas. Faringe com uma ou mais sinuosidades, com trépano na margem anterior, com, no mínimo, 20 dentes pequenos.

Comentários: o gênero já apresenta registro de três diferentes, ocorrendo no litoral brasileiro: M. brachycephala (Marenzeler, 1874), M. prolifera (Müller, 1788) e M. convoluta (Coqnetti, 1953), sendo que M. prolifera possui registro apenas para o litoral do Rio de Janeiro (MACHADO, 1986), enquanto as outras duas espécies possuem registro para o litoral paulista, na Laje de Santos e em Ubatuba, respectivamente (NOGUEIRA, 2000; NOGUEIRA \& AMARAL, 1997).

\section{Myrianida prolifera (O.F. Müller, 1788)}

Fig. 1

Nereis prolifera O. F. MÜLLER, 1788: 15, pl. 52, fig. 5-9.

Myrianida prolifera NYGREN, 2004: 151-152, fig. 75A-E.

Material analisado: São Sebastião - Praia de São Francisco, em Sargassum: 9 esp., 16.Jun.2015. São Sebastião - Praia de São Francisco, em Gracilaria: 7 esp., 16.Jun.2015. Todos os indivíduos foram coletados na zona entremarés.

Descrição: animais com porte pequeno, com 1,25-4,5 mm de comprimento, 75 22 setígeros, e $0,3-0,15 \mathrm{~mm}$. Corpo subcilíndrico sem pigmentação, com 1 fileira transversal de grânulos por segmento. Palpos rebatidos ventralmente, cobertos pelo prostômio e fundidos em mais da metade de seu comprimento; 2 pares de olhos em trapézio e 1 par de manchas ocelares; antena mediana inserida 
na linha dos olhos anteriores, com o dobro do comprimento das laterais, estas inseridas na região anterior do prostômio. Peristômio conspícuo, com tamanho similar aos segmentos seguintes, par dorsal de cirros de mesmo comprimento das antenas laterais, par ventral com $2 / 3$ daquele comprimento. Cirros dorsais do setígero 1 de mesmo comprimento da antena mediana, os dos demais setígeros com ligeira alternância de tamanho em toda a extensão do corpo, com aproximadamente metade do comprimento das antenas laterais. Cirros peristomiais e cirros dorsais ao longo do corpo com cirróforos e cirróstilos, estes últimos subcilíndricos. Parapódios com 2 acículas em todos os setígeros, podendo apresentar 1 na região posterior, estas levemente inclinadas na região subdistal e arredondadas distalmente; cerdas falcígeras bidentadas, com dente subdistal maior e espinulação na margem da lâmina (Fig. 1B); 6-10 falcígeras por parapódios nos setígeros anteriores, 5-8 nos medianos e 4-8 nos posteriores; lâminas das falcígeras com variação ântero-posterior e dorso-ventral no comprimento, $10-5 \mu \mathrm{m}$ nos setígeros anteriores, 7,5-5 $\mu \mathrm{m}$ nos medianos e $5 \mu \mathrm{m}$ nos posteriores. Cerdas simples dorsais em baioneta (Fig. 1C), presentes nos setígeros posteriores. Pígidio com par de cirro anais de mesmo comprimento das antenas laterais. Faringe estendendo-se por 6-7 segmentos, com 1 sinuosidade; trépano com 26-34 dentes de mesmo tamanho (Fig. 1A), dos quais 16-20 dorsais e 10-14 ventrais. Proventrículo se estendendo por 3-4 segmentos.

Discussão: Essa espécie se assemelha muito a M. edwersi (Saint-Joseph, 1887) e M. brachycepala (Marenzeler, 1874), contudo exemplares da primeira espécie possuem uma pigmentação muito característica, vermelho alaranjada em todo o corpo, enquanto os de $M$. prolifera são desprovidos de pigmentação; além disso, M. edwarsi apresenta cirros similares em toda a extensão de seu corpo, enquanto em M. prolifera eles são desiguais. Em relação a M. brachycephala, esta tem o anel basal do trépano fino, diferente do que acontece em indivíduos de $M$. prolifera, onde anel basal é robusto. Suspeita-se que essas espécies sejam capazes de se hibridizar, contudo nada foi ainda comprovado (HAMOND, 
1969a; SCHIEDGES, 1979a, 1979b, 1980).

Localidade-tipo: Oceano Atlântico, próximo à Noruega.

Distribuição: Principalmente no litoral europeu: França, Ilhas Faroé, País de Gales, Suécia e Noruega (NYGREN, 2004). Com ocorrências na costa brasileira, no Rio de Janeiro (MACHADO, 1986) (Oceano Atlântico).

Figura 1- Myrianida prolifera. A, trépano, sendo o lado ventral representada por "v"e o lado dorsal por "d"; $\mathbf{B}$, cerdas falcígeras; $\mathbf{C}$, cerda simples dorsal. Barras de escala $\mathbf{A}-\mathbf{C}=10 \mu \mathrm{m}$.

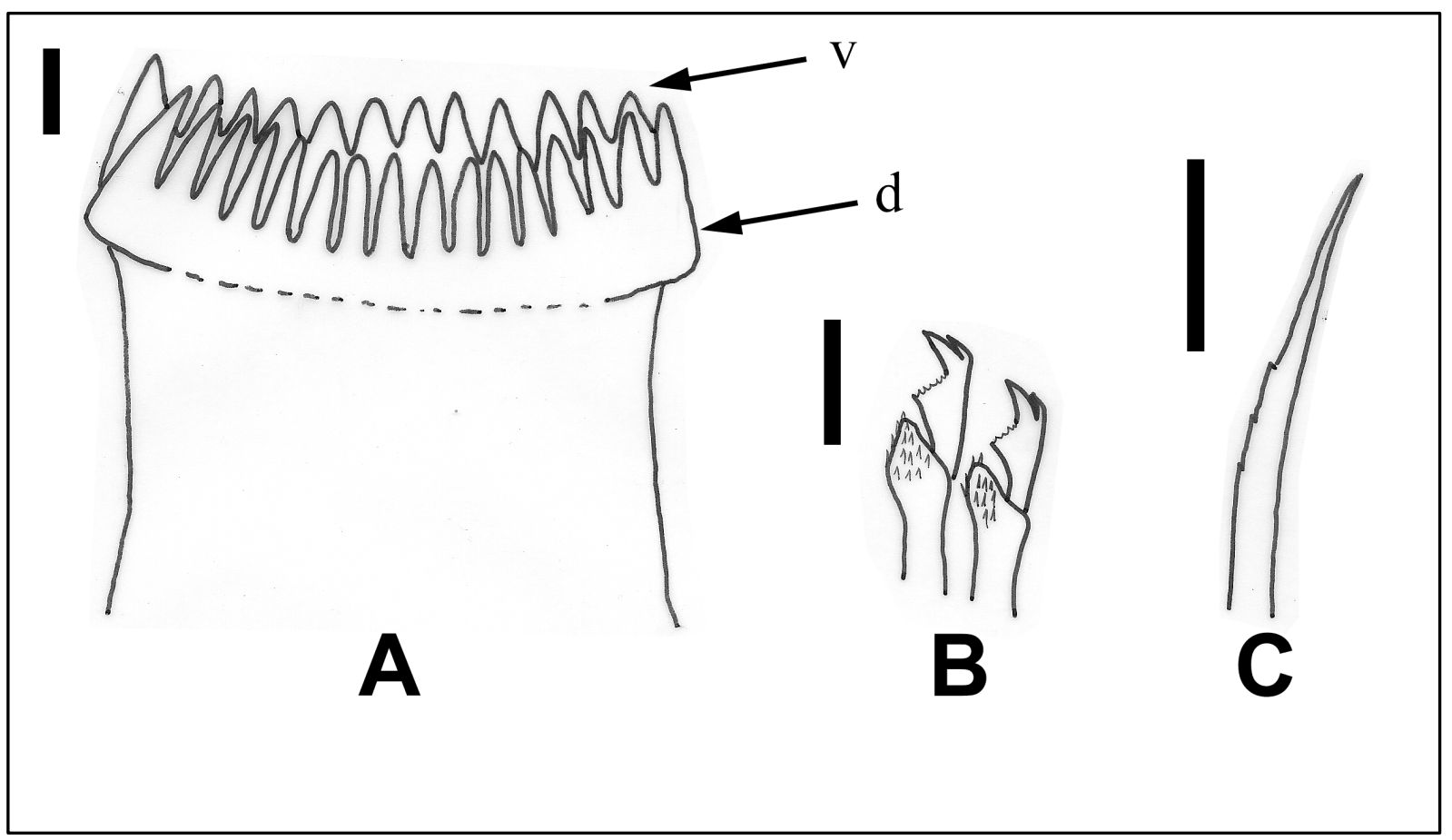

Fonte: Desenho de autoria própria.

Gênero Proceraea Ehlers, 1864

Espécie-tipo: Proceraea picta Ehlers, 1864

Diagnose: Prostômio arredondado, com palpos totalmente fundidos, 2 pares de olhos em trapézio, algumas espécies também com 1 par de manchas ocelares, e 3 antenas. Peristômio com 2 pares cirros, um dorsal e outro ventral. Cirróforos e cirróstilos presentes apenas nas três antenas, nos cirros peristomiais dorsais e nos cirros do primeiro setígero, ausentes nos demais setígeros e nos peristomiais ventrais, estes últimos com cirros dorsais cilíndricos, com extremidade 
arredondada. Cerdas falcígeras bidentadas, espinuladas, com dente subdistal maior; cerdas simples dorsais em baioneta. Faringe com, no mínimo, uma sinuosidade; trépano com dentes de tamanhos distintos.

Comentários: o gênero já foi registrado para o Brasil, com as espécies $P$. okadai (Imajima, 1966) (FUKUDA, 2010), P. picta Ehlers, 1864 (NOGUEIRA, 2000) e P. rubroproventriculata Nygren \& Gidhol, 2001 (PARESQUE et al., 2012a), sendo que, a primeira foi encontrada em vários pontos do litoral paulista, a segunda foi encontrada tanto no litoral paulista, quanto no nordestino, e terceira foi encontrada apenas no litoral do nordeste.

\section{Proceraea hanssoni Nygren, 2004}

Fig. 2, 3

Proceraea hanssoni NYGREN, 2004: 53-55, fig. 13A-H.

Material analisado: São Sebastião - Praia de São Francisco, em Sargassum: 2 esp., 16.Jun.2015. Ambos os indivíduos foram coletados na zona entremarés.

Descrição: animais de médio porte, com 5-10,5 $\mathrm{mm}$ de comprimento, 52-76 setígeros, e 0,375-0,625 mm de largura. Corpo subcilíndrico, com pigmentação conspícua, apresentando uma faixa transversal dorsal castanho escura a preta, na região anterior de cada setígero (Fig. 3A). Prostômio arredondado, com palpos completamente fundidos, visíveis dorsalmente, distalmente arredondados; 2 pares de grandes olhos vermelho escuros dispostos em trapézio, manchas ocelares ausentes; antena mediana com o dobro do comprimento das laterais, inserida entre a linha dos olhos anteriores, as laterais inseridas na margem anterior do prostômio. Cirros peristomiais dorsais com mesmo comprimento das antenas laterais, cirros peristomiais ventrais com $1 / 3$ daquele comprimento. 
Cirros dorsais do setígero 1 quase de mesmo comprimento da antena mediana, os dos demais setígeros pequenos e cilindrícos, muito menores do que as antenas laterais; divisão em cirróforo e cirróstilo apenas nos cirros peristomiais e dorsais do setígero 1. Parapódios com apenas 1 acícula em todos os setígeros, esta subdistalmente inclinada e distalmente arredondada; lâminas das cerdas falcígeras bidentadas e espinuladas, com dente subdistal maior (Fig. 2B-C); parapódios com 7-8 cerdas nos setígeros anteriores, 3-5 nos medianos e 3-4 nos posteriores; lâminas das falcígeras com pequena variação no comprimento, 7,5$5 \mu \mathrm{m}$ em todos os setígeros; cerdas simples dorsais em baioneta presentes nos setígeros posteriores (Fig. 2D). Pígidio com cirros anais do mesmo comprimento dos cirros peristomiais ventrais. Faringe com sinuosidade anterior, se estendendo por 6-5 segmentos (Fig. 3B); trépano com 18 dentes de tamanhos diferentes (Fig. 2A), com número similar de dentes nas metades dorsal e ventral. Proventrículo se estendendo por 2-4 segmentos, com 34-39 feixes musculares.

Discussão: Exemplares de P. fasciata (Bosc, 1802) e P. madeirensis Nygren, 2004 também possuem faixas transversais no dorso, contudo na primeira espécie elas apresentam uma pigmentação mais avermelhada, apresentando mais de 43 feixes musculares no proventriculo. $\mathrm{Na}$ segunda espécie, as mesmas são castanhas, apresentando pigmentação nas antenas e cirros peristomiais, enquanto as lâminas das falcígeras apresentam os dois dentes de mesmo tamanho.

Localidade-tipo: Costa Pacífica dos Estados Unidos, Estado de Washington, Ilha de San Juan $\left(48^{\circ} 32.73^{\prime} \mathrm{N}, 123^{\circ} 00.75^{\prime} \mathrm{O}\right)$.

Distribuição: Até o presente estudo, a espécie só havia sido encontrada na localidade-tipo, tratando-se este, portanto, do primeiro registro desta espécie tanto para o Oceano Atlântico, quanto para o litoral brasileiro. 
Fig. 2 - Proceraea hanssoni. A, trépano; B, cerda falcígera, região anterior; C, cerda falcígera, região posterior; $\mathbf{D}$, cerda simples dorsal. Barras de escala: $\mathrm{A}=0,1 \mu \mathrm{m} ; \mathrm{B}-\mathrm{C}=10$ $\mu \mathrm{m}$ e $\mathrm{D}=5 \mu \mathrm{m}$.
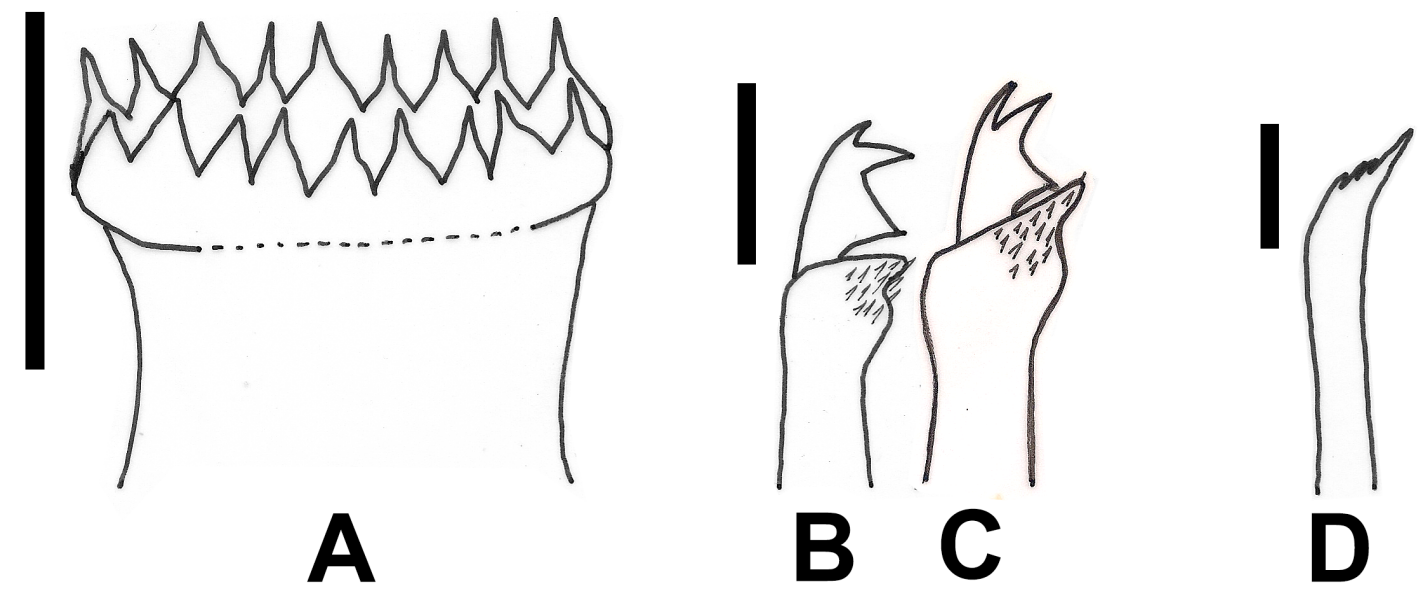

Fonte: Desenho de autoria própria.

Fig. 3 - Proceraea hanssoni. A, região anterior, vista dorsal; B, faringe e proventrículo, vista dorsal. Barras de escala: $\mathrm{A}=0,2 \mu \mathrm{m} ; \mathrm{B}=0,1 \mathrm{~mm}$.

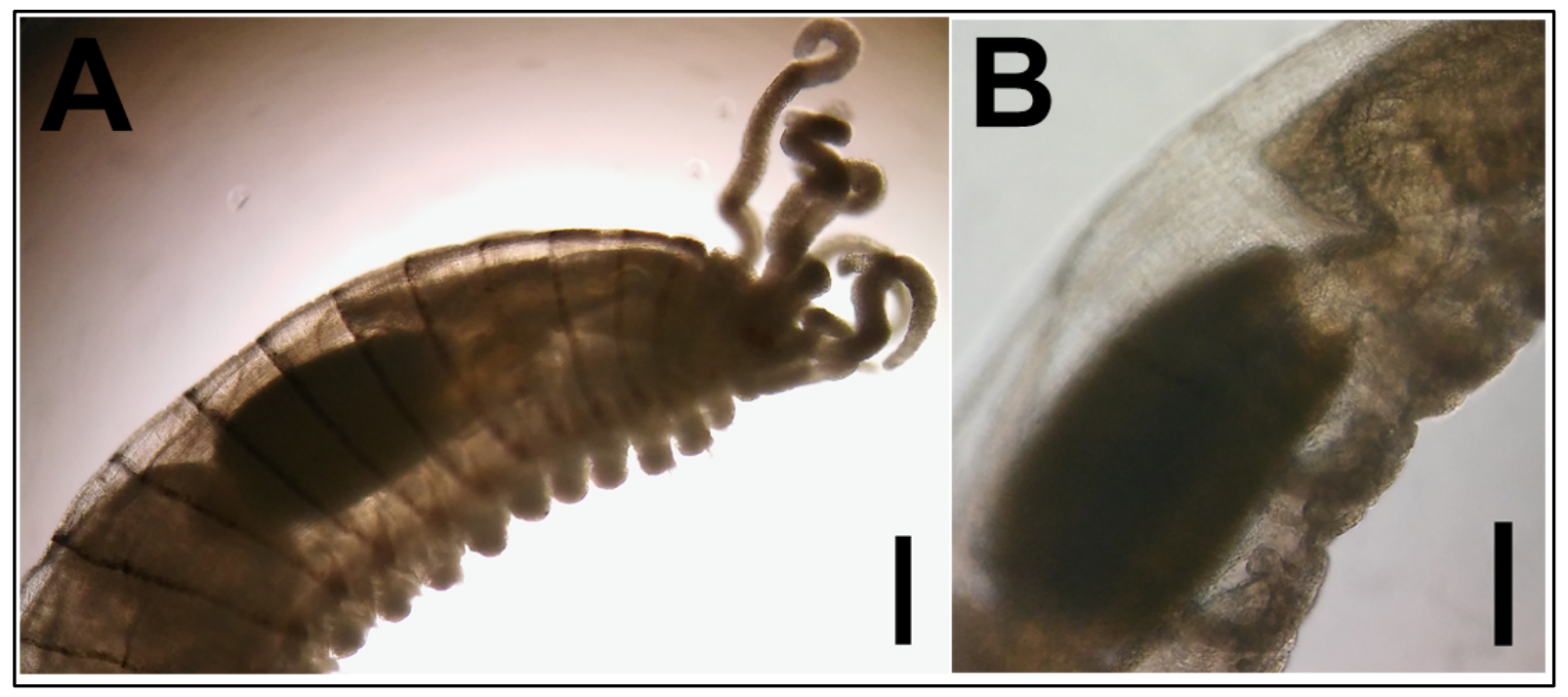

Fonte: Fotografia de autoria própria. 


\section{Subfamília Eusyllinae Malaquin, 1893}

Diagnose: animais de porte médio, subcilíndricos, com palpos fundidos apenas na base. Antenas, cirros peristomiais e dorsais ao longo do corpo longos, lisos ou pseudoarticulados. Faringe, na maioria dos casos, reta, com trépano e/ou um dente central.

Comentários: esta subfamília está sob intenso processo de revisão, pois há muitas suspeitas de que não seja um grupo monofilético (SAN MARTÍN \& HUTCHINGS, 2006; AGUADO et al., 2007). A última das subfamílias de Syllidae a ser descrita, Anoplosyllinae Aguado \& San Martín, 2009, é composta por animais anteriormente considerados como eusilíneos, e outros táxons também anteriormente considerados como eusilíneos são atualmente tratados como incertae sedis (AGUADO \& SAN MARTÍN, 2009; AGUADO et al., 2012).

\section{Chave de identificação para os gêneros de Eusyllinae encontrados neste estudo}

1a. Faringe sem trépano, com dente único próximo à margem anterior da faringe. Perkynsyllis

1b. Faringe com trépano, podendo ou não apresentar também um dente central.

2a. (1b) Trépano formado por uma coroa incompleta de pequenos dentes e dente central maior. Eusyllis

2b. Trépano formado por uma coroa de dentes voltados para trás, podendo apresentar 1 par de placas laterais, sem dente central. Odontosyllis 


\section{Gênero Eusyllis Malmgren, 1867}

Espécie-tipo: Eusyllis blomstrandi Malmgren, 1867

Diagnose: animais de tamanho corpóreo pequeno a médio. Prostômio com 2 pares de olhos em trapézio, algumas espécies também com 1 par de manchas ocelares, e 3 antenas. Peristômio com 2 pares de cirros, um dorsal e outro ventral. Antenas, cirros peristomiais e cirros dorsais ao longo do corpo lisos ou pseudoarticulados. Cerdas simples dorsais e ventrais presentes apenas nos setígeros posteriores. Faringe com trépano, com coroa de pequenos dentes completa ou não, e dente central maior.

Comentários: o gênero possui muitos registros no litoral brasileiro (AMARAL et al., 2013), mas apenas para três espécies E. assimilis Marenzeler, 1875, E. lamelligera Marion \& Bobretzky, 1875 e E. kupfferi Langerhans, 1879. As três já foram encontradas no litoral paulista em diversos pontos (FUKUDA, 2010), E. lamelligera possui, também, registros no litoral carioca e E. assimilis, no litoral sul.

\section{Chave de identificação para as espécies de Eusyllis encontradas neste estudo}

- Corpo sem pigmentação; falcígeras com lâminas bidentadas, com dentes aproximadamente de mesmo tamanho nos setígeros anteriores, o subdistal ligeiramente maior nos setígeros posteriores. E. assimilis

- Corpo com pigmentação conspícua, apresentando duas faixas transversais por setígero; falcígeras com lâminas unidentadas e longas E. kupfferi 


\section{Eusyllis assimilis Marenzeller, 1875}

Fig. 4

Eusyllis assimilis SAN MARTÍN, 2003: 114-117, figs. 52-53; SAN MARTÍN \& HUTCHINGS, 2006: 273-276, figs. 10-12A-C; FUKUDA, 2010: 35-38, fig. 7.

Material analisado: São Sebastião - Praia Grande, em Caulerpa lentilifera: 1 esp., 13.Dez.2015. Coletado na zona entremarés.

Descrição: animal de pequeno porte, com corpo subcilíndrico, com 1,5 mm de comprimento, apresentando 16 setígeros, e com 0,25 mm de largura. Prostômio ovalado com 2 pares de olhos em trapézio e 1 par de manchas ocelares. Palpos ovais, fundidos apenas na região basal, visíveis dorsalmente. Antena mediana inserida entre os 4 olhos, as laterais pouco à frente dos olhos anteriores. Orgãos nucais localizados atrás dos olhos posteriores, na margem do prostômio. Peristômio curto, cirros peristomiais dorsais com o dobro do tamanho das antenas laterais, cirros peristomiais ventrais com o mesmo tamanho das mesmas. Cirros dorsais do setígero 1 maiores do que os peristomiais dorsais, os demais alternando cirros curtos, de mesmo tamanho dos cirros peristomiais ventrais, e longos, com comprimento similar ao dos cirros peristomiais dorsais. Antenas, cirros peristomiais, dorsais ao longo do corpo e anais pseudoarticulados; cirros ventrais ovais, mais curtos do que os lobos parapodiais. Parapódios com 2 acículas na região anterior e 1 a partir da região mediana, tendo estas a extremidade arredondada e ligeiramente oblíqua próximo ao ápice anterior (Fig. 4E). Cerdas falcígeras bidentadas e levemente espinuladas, com dentes subdistal e distal de mesmo tamanho na região anterior, com ligeira gradação de aumento do dente subdistal em direção posterior (Fig. 4A-B). Parapódios com 15 cerdas na região anterior, 10 na mediana e 5 na posterior. Lâminas das falcígeras com variações dorso-ventral e ântero-posterior, medindo 35-20 $\mu \mathrm{m}$ na região 
anterior, $25-15 \mu \mathrm{m}$ na mediana e $15-10 \mu \mathrm{m}$ na posterior. Cerdas simples dorsais unidentadas (Fig. 4C); cerdas simples ventrais bidentadas (Fig. 4D), presentes apenas na região posterior. Pígidio com cirros anais do mesmo tamanho dos cirros peristomiais dorsais. Faringe ocupando cerca de 4 segmentos, com trépano e dente central. Proventrículo estendendo-se por 3 segmentos, com 23 feixes musculares de difícil identificação.

Discussão: a espécie em questão e E. lamelligera apresentam ambas cerdas com lâminas bidentadas muito semelhantes. Contudo, indivíduos de E. lamelligera possuem uma morfologia característica nos cirros ventrais do primeiro setígero, ausente em membros de E. assimilis, e os dentes das lâminas de suas falcígeras possuem o mesmo tamanho ao longo de todo o corpo, enquanto em membros de E. assimilis o dente subdistal aumenta progressivamente, em direção posterior.

Localidade-tipo: Itália, Mar Adriático (Oceano Atlântico).

Distribuição: Espécie cosmopolita, com registro na Austrália (Oceano Índico); Austrália e Nova Zelândia (Oceano Pacífico); e Mar Mediterrâneo, Canal da Mancha à África do Sul, Canadá ao México e Brasil, no litoral sul e, principalmente, no litoral paulista (Oceano Atlântico).

Fig. 4- Eusyllis assimilis. A, cerdas falcígeras, região anterior; B, cerdas falcígeras, região posterior; $\mathbf{C}$, cerda simples dorsal; $\mathbf{D}$, cerda simples ventral; E, acículas da região anterior. Barra de escala: A-B $=10 \mu \mathrm{m} ; \mathrm{C}-\mathrm{E}=5 \mu \mathrm{m}$.

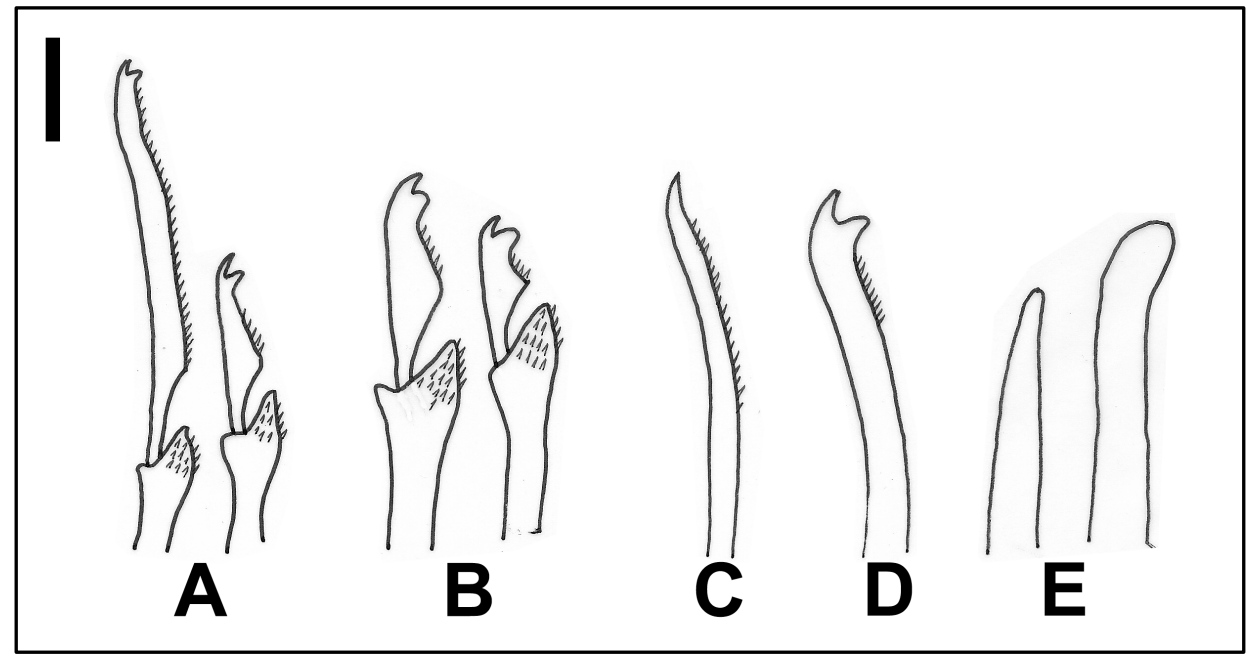

Fonte: Desenho de autoria própria. 


\section{Eusyllis kupfferi Langerhans, 1879}

Fig. 5

Eusyllis kupfferi SAN MARTÍN \& HUTCHINGS, 2006: 276-278, fig. 12D-F, 13-14; FUKUDA, 2010: 38-40, fig. 8 .

Material analisado: São Sebastião - Praia da Baleia, em Dyctiota ciliolata: 1 esp., 08.Abr.2016. Incompleto, animal partido na região posterior. Coletado na zona entremarés.

Descrição: animal de pequeno porte, com corpo subcilíndrico, com 1,125 mm de comprimento, apresentando 21 setígeros, e com $0,125 \mathrm{~mm}$ de largura. Pigmentação característica, com 2 faixas transversais dorsais de tonalidade marrom, estando uma na borda posterior dos segmentos e a outra na região mediana dos segmentos com um padrão descontínuo. Prostômio ovalado com 2 pares de olhos em retângulo, sem manchas ocelares. Palpos ovalados, fundidos apenas na região basal, visíveis dorsalmente. Antena mediana, com o dobro do tamanho das laterais, inserida entre os 4 olhos, as laterais pouco à frente dos olhos anteriores. Peristômio de mesmo tamanho dos segmentos, cirros peristomiais dorsais com o dobro do tamanho das antenas laterais, cirros peristomiais ventrais com o mesmo tamanho das mesmas. Cirros dorsais do setígero 1, aproximadamente 3 vezes maiores do que os peristomiais ventrais, os demais de mesmo tamanho das antenas laterais, sem alternância de tamanho. Antenas, cirros peristomiais, dorsais ao longo do corpo e anais pseudoarticulados; cirros ventrais ovais, de mesmo tamanho dos lóbulos parapodiais. Parapódios com 1 acícula em todo o corpo, sendo estas distalmente infladas e arredondadas, possivelmente ocas (Fig. 5C). Cerdas falcígeras unidentadas e levemente espinuladas (Fig. 5A-B). Parapódios com 10 cerdas na região anterior e 8 na região mediana. Lâminas das falcígeras com variações 
dorso-ventral e ântero-posterior, medindo $27-20 \mu \mathrm{m}$ na região anterior e 17,512,5 $\mu \mathrm{m}$ na mediana. Cerdas simples dorsais em baioneta e espinuladas, surgindo a partir da região mediana; cerdas simples ventrais ausentes. Pígidio com cirros anais de mesmo tamanho dos cirros peristomiais dorsais. Faringe ocupando cerca de 3 segmentos, com trépano e dente central. Proventrículo estendendo-se por 5 segmentos, com 56 feixes musculares.

Discussão: a espécie possui registro tanto na costa brasileira quanto na australiana, europeia e norte americana. Contudo, essas apresentam algumas diferenças morfológicas em relação à descrição dos exemplares australianos, como, por exemplo, existência de uma gradação dorso-ventral no comprimento das lâminas das cerdas, duas faixas incontínuas de pigmentação na região dorsal de cada setígero e um número superior de feixes musculares no proventrículo (FUKUDA, 2010). O exemplar analisado no presente trabalho se assemelha aos espécimes registrados para o nosso litoral.

Localidade-tipo: Golfo de Marselha, França, Mar Mediterrâneo (Oceano Atlântico).

Distribuição: Queensland, Western Australia e New South Wales, Austrália (Oceano Pacífico). Canal da Mancha ao Mar Mediterrâneo, norte dos EUA a Cuba, São Paulo, Brasil (Oceano Atlântico).

Fig. 5 - Eusyllis kupfferi. A, cerdas falcígeras, região anterior; $\mathbf{B}$, cerdas falcígeras, região posterior; $\mathbf{C}$ acícula da região anterior. Barra de escala: $\mathrm{A}-\mathrm{C}=10 \mu \mathrm{m}$.

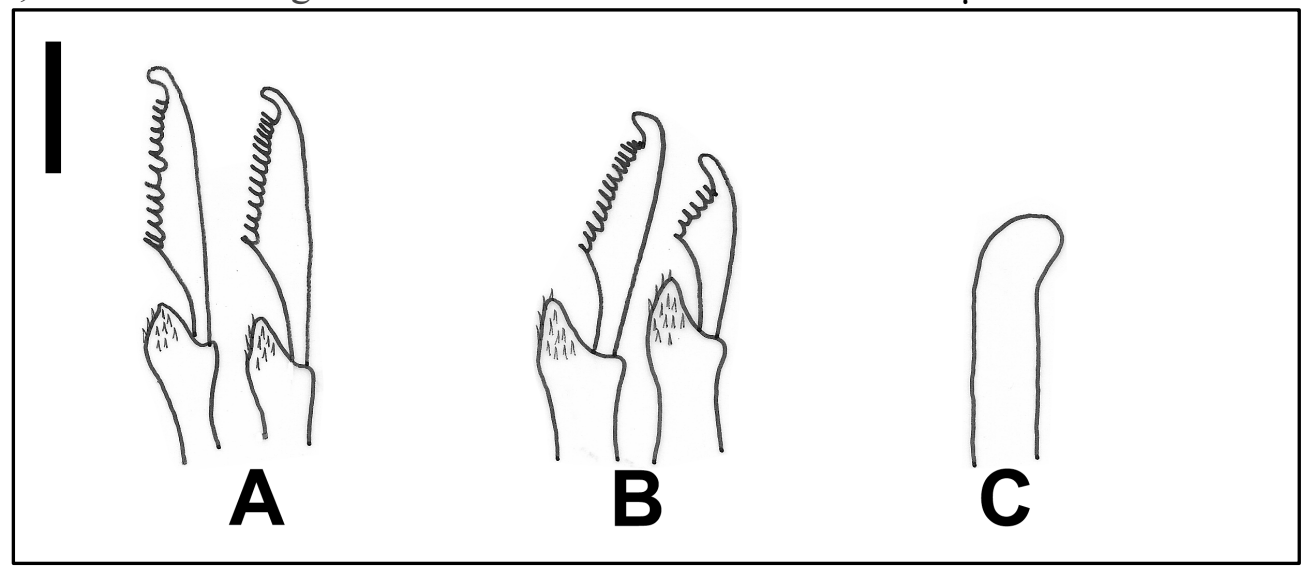

Fonte: Desenho de autoria própria. 


\section{Gênero Odontosyllis Claparède, 1863}

Espécie-tipo: Syllis fulgurans Audouin \& Milne Edwards, 1833.

Diagnose: animais de tamanho corpóreo médio a grande. Prostômio com 2 pares de olhos em trapézio e 3 antenas. Peristômio com 2 pares de cirros peristomiais, um dorsal e outro ventral; lóbulo nucal arredondado, recobrindo a parte posterior do prostômio, presente em membros da maioria das espécies. Antenas, cirros peristomiais e dorsais ao longo do corpo lisos ou pseudoarticulados. Cerdas compostas falcígeras presentes em todo o corpo. Faringe com trépano, com coroa incompleta, na maioria dos casos, de pequenos dentes voltados para trás.

Comentários: o gênero conta com 4 espécies registradas para o litoral brasileiro: O. fulgurans (Audouin \& Milne Edwards, 1833), O. polycera (Schmarda, 1861), O. hetero-falchaeta Temperini, 1981 e O. guillermoi Fukuda \& Nogueira, 2006, embora O. hetero-falchaeta tenha sido descrita numa Dissertação de Mestrado (TEMPERINI, 1981) e nunca formalmente publicada. O gênero é facilmente identificado devido à morfologia do trépano, com os dentes virados em direção posterior, e pela presença do lóbulo nucal.

\section{Chave de identificação para as espécies de Odontosyllis encontradas neste estudo}

1a. Cirros pseudoarticulados na região anterior do corpo. Lóbulo nucal comprido, chegando próximo à base da antena central, com largura de aproximadamente metade do prostômio........................... Odontosyllis sp.1 sp. nov. 1b. Cirros lisos em toda a extensão do corpo. Lóbulo nucal com morfologia diferente. 
2a.(1b) Falcígeras com lâminas com dentes de mesmo tamanho. Corpo sem pigmentação O. cf. fulgurans

2b. Falcígeras com lâminas com dente subdistal menor do que o distal. Corpo com duas linhas pretas transversais no dorso por segmento, pelo menos na metade anterior do corpo

O. guillermoi

\section{Odontosyllis cf. fulgurans (Audouin \& Milne Edwards, 1833)}

Fig. 6

Odontosyllis fulgurans. SAN MARTÍN, 2003: 104, fig. 46-47; NOGUEIRA, 2000: 89-90, fig. 20 L-O; 2006: 147.

Odontosyllis cf. fulgurans. FUKUDA \& NOGUEIRA, 2006: 229-232, figs. 3-4; FUKUDA, 2010: 48-52, figs. 11-12.

Material analisado: São Sebastião - Praia de São Francisco, em Sargassum sp: 4 esp., 16.Jun.2015; em Gracilaria sp.: 2 esp., 16.Jun.2015; em Hypnea musciform: 7 esp., 16.Jun.2015. Praia Grande, em Caulerpa lentilifera: 5 esp., 30.Jun.2015; 4 esp., 13.Dez.2015. Praia da Baleia, em Dyctiota ciliolata: 1 esp., 08.Abr.2016. Todos os indivíduos foram coletados na zona entremarés.

Descrição: animais de tamanho corpóreo pequeno a médio, com corpo subcilíndrico, entre 1-6,5 $\mathrm{mm}$ de comprimento, apresentando entre 19-78 setígeros, e com largura entre $0,125-0,625 \mathrm{~mm}$. Prostômio ovalado com 2 pares de olhos em trapézio. Palpos oval a triangulares, fundidos apenas na região basal, visíveis dorsalmente. Antena mediana inserida entre o par de olhos anteriores, as laterais, com $2 / 3$ do tamanho da mediana, inseridas na margem anterior do prostômio. Peristômio com metade do tamanho dos segmentos, com cirros peristomiais dorsais com o dobro do tamanho dos ventrais, estes com mesmo tamanho das antenas laterais; lóbulo nucal pequeno, arredondado, não 
alcançando a linha dos olhos posteriores. Cirros dorsais com comprimento similar à antena mediana, com exceção dos cirros do primeiro setígero, que são mais compridos. Antenas, cirros peristomiais, dorsais ao longo do corpo e anais lisos; cirros ventrais ovais, pouco menores do que os lóbulos parapodiais. Parapódios com 1-2 acículas nas regiões anterior e mediana, e 1 acícula na região posterior, podendo apresentar espinhas na região subdistal e um afilamento no ápice (Fig. 6D). Cerdas falcígeras bidentadas, com dentes de mesmo tamanho e levemente espinuladas (Fig. 6A). Parapódios com 8-18 cerdas na região anterior, 7-14 na mediana e 6-8 na posterior. Lâminas das falcígeras com variações dorso-ventral e ântero-posterior, no caso das cerdas mais dorsais, medindo $20-5 \mu \mathrm{m}$ na região anterior, $15-5 \mu \mathrm{m}$ na mediana e $15-5$ $\mu \mathrm{m}$ na região posterior. Cerdas simples dorsais espinuladas, arredondadas distalmente (Fig. 6B), presentes apenas na região posterior; cerdas simples ventrais, quando presentes, bidentadas e espinuladas, com dente distal maior do que o subdistal (Fig. 6C). Pígidio com cirros anais de mesmo tamanho dos cirros peristomiais ventrais. Faringe ocupando 2-6 segmentos, com trépano incompleto, apresentando de 5-6 dentes na região ventral e 2 placas laterais. Proventrículo estendendo-se por 3-8 segmentos, com 56-65 feixes musculares.

Discussão: os espécimes estudados se assemelharam mais com os já descritos para o litoral brasileiro (FUKUDA \& NOGUEIRA, 2006; FUKUDA, 2010), do que com aqueles que descritos a partir de exemplares da Península Ibérica (SAN MARTÍN, 2003).

Localidade-tipo: Mar Mediterrâneo, França (Oceano Atlântico).

Distribuição: Espécie cosmopolita. 
Fig. 6 - Odontosyllis cf. fulgurans. A, cerdas falcígeras; $\mathbf{B}$, cerda simples dorsal; $\mathbf{C}$, cerda simples ventral; $\mathbf{D}$, acícula da região anterior. Barra de escala: $A-D=5 \mu \mathrm{m}$

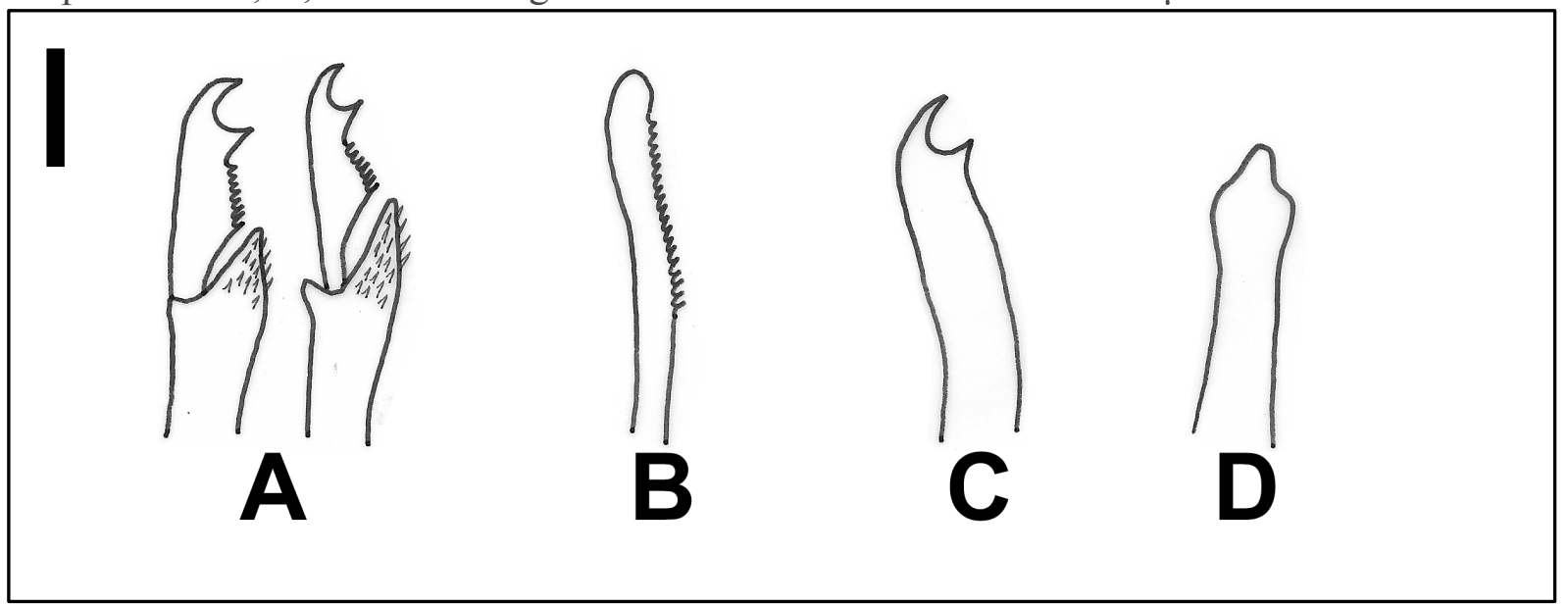

Fonte: Desenho de autoria própria.

\section{Odontosyllis guillermoi Fukuda \& Nogueira, 2006}

Fig. 7

Odontosyllis guillermoi. FUKUDA \& NOGUEIRA, 2006: 225-229, figs. 1-2; FUKUDA, 2010: 52-56, fig. 13.

Material analisado: São Sebastião - Praia de São Francisco, em Sargassum sp.: 2 esp., 16.Jun.2015; em Gracilaria sp.: 2 esp., 16.Jun.2015; em Hypnea musciform: 30 esp., 16.Jun.2015. Praia Grande, em Caulerpa lentilifera: 1 esp., 13.Dez.2015. Todos os indivíduos foram coletados na zona entremarés.

Descrição: animais de tamanho corpóreo médio, com corpo subcilíndrico, entre 0,875-4,375 $\mathrm{mm}$ de comprimento, apresentando entre 11-46 setígeros, e com largura entre $0,225-0,5 \mathrm{~mm}$. Corpo com pigmentação característica, com faixas negras entre os olhos, uma faixa na região anterior do prostômio e 2 faixas transversais por setígero. Prostômio arredondado com 2 pares de olhos em trapézio. Palpos ovalados, separados, visíveis dorsalmente. Antena mediana inserida entre o par de olhos anteriores, as laterais, pouco menores do que a mediana, inseridos na margem anterior do prostômio. Peristômio com metade do tamanho dos segmentos, cirros peristomiais dorsais de mesmo tamanho da 
antena mediana, cirros peristomiais ventrais de mesmo tamanho das antenas laterais; lóbulo nucal grande, arredondado, alcançando a base da antena central. Cirros dorsais com alternância de comprimento, os curtos com 2/3 do comprimento dos longos. Antenas, cirros peristomiais, dorsais ao longo do corpo e anais lisos, com fileiras laterais de papilas; cirros ventrais ovais, pouco menores do que os lóbulos parapodiais. Parapódios com 4-5 acículas na região anterior, 2-3 na região mediana e 1 na região posterior, a maioria distalmente inflada, com a ponta afilada, e 1 afilada e pontiaguda (Fig. 7C). Cerdas falcígeras curtas e bidentadas, com dente distal maior do que o subdistal e levemente espinuladas (Fig. 7A). Parapódios com 10-15 cerdas na região anterior, 9-12 na mediana e 8-12 na região posterior. Lâminas das falcígeras com pequenas variações dorso-ventral e ântero-posterior, medindo 12,5-10 $\mu \mathrm{m}$ na região anterior, $12,5-10 \mu \mathrm{m}$ na mediana e $12,5-7,5 \mu \mathrm{m}$ na posterior. Cerdas simples dorsais unidentadas e espinuladas, presentes a partir da região mediana (Fig. 7B); cerdas simples ventrais bidentadas e espinuladas, com dente distal maior do que o subdistal, presentes na região posterior. Pígidio com cirros anais longos, de mesmo tamanho dos cirros peristomiais dorsais. Faringe ocupando 4 7,5 segmentos, com trépano incompleto com 5 dentes na região ventral e 2 placas laterais. Proventrículo estendendo-se por 3-6 segmentos, com feixes musculares de difícil visualização.

Discussão: a espécie é conhecida apenas para o litoral brasileiro. Assim como outras espécies do gênero, ela possui cerdas falcígeras com lâminas curtas e bidentadas, contudo outras características como a morfologia do lóbulo nucal, número de acículas por parapódio, número de dentes no trépano e padrões de coloração diferenciam membros destas espécies. As espécies que mais se assemelham a O. guillermoi são: O. fragilis Kudenov \& Harris, 1995, O. luminosa San Martín, 1990 e O. fulgurans (Audouin \& Milne Edwards, 1833).

Odontosyllis fragilis também possui padrão de pigmentação com faixas transversais, contudo membros desta espécie têm apenas uma faixa por 
segmento, enquanto em $O$. guillermoi há duas faixas por segmento. Além disso, o trépano de indivíduos daquela espécie possui apenas 5 dentes, as falcígeras têm o dente subdistal maior que o distal e há 2 acículas por parapódio ao longo de todo o corpo. Membros de $O$. guillermoi, em contrapartida, possuem 6 dentes no trépano, nas falcígeras o dente distal é maior do que o subdistal e existe uma gradação no número de acículas por parapódio ao longo do corpo.

Exemplares de $O$. fulgurans diferem dos da espécie em questão por não apresentarem pigmentação e possuirem um lóbulo nucal bastante menor. Em relação aos parapódios, membros desta espécie possuem as lâminas das falcígeras com dentes de aproximadamente o mesmo tamanho e há no máximo 2 acículas por parapódio, enquanto em membros de $O$. guillermoi os parapódios anteriores têm 4-5 acículas cada um.

Indivíduos de $O$. luminosa não possuem padrão de pigmentação e suas falcígeras possuem os dentes mais próximos entre si. Apresentam apenas uma acícula por parapódio e seus cirros dorsais e antenas são mais longos, quando comparados com os de espécimes de $O$. guillermoi.

Localidade-tipo: Praia Branca, Guarujá, Brasil (Oceano Atlântico).

Distribuição: São Paulo, Brasil (Oceano Atlântico).

Fig. 7- Odontosyllis guillermoi. A, cerdas falcígeras; $\mathbf{B}$, cerda simples dorsal; $\mathbf{C}$, acícula da região anterior. Barra de escala: $\mathrm{A}-\mathrm{C}=10 \mu \mathrm{m}$.

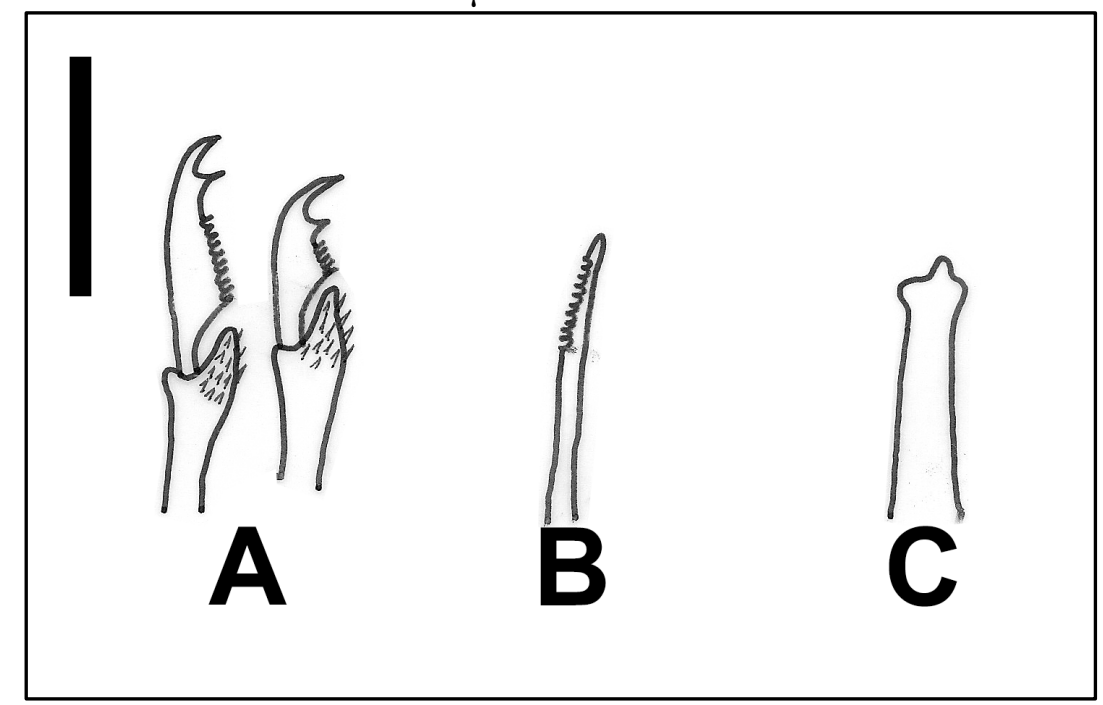

Fonte: Desenho de autoria própria. 


\section{Odontosyllis sp. 1 sp. nov.}

Figs. 8, 9

Material analisado: São Sebastião - Praia de São Francisco, em Hypnea musciform: 12 esp., 16.Jun.2015. Todos os indivíduos foram coletados na zona entremarés.

Descrição: animais de tamanho corpóreo pequeno, com corpo subcilíndrico, entre 0,875-3,375 $\mathrm{mm}$ de comprimento, apresentando entre 40-30 setígeros, e com largura entre 0,25-0,5 mm (Fig. 9A). Corpo sem pigmentação. Prostômio arredondado, com 2 pares de olhos em trapézio. Palpos ovalados, separados, visíveis dorsalmente. Antena mediana inserida entre o par de olhos anteriores, as laterais pouco menores do que a mediana, inseridas na margem anterior do prostômio. Peristômio com metade do tamanho dos segmentos, cirros peristomiais dorsais com o dobro do tamanho da antena mediana, cirros peristomiais ventrais de mesmo tamanho das antenas laterais; lóbulo nucal grande, amplo, com metade da largura do prostômio, alcançando a base da antena mediana e cobrindo os olhos posteriores (Figs. 8A, D; 9A). Cirros dorsais menores do que a antena central, com exceção dos cirros dos dois primeiros setígeros, que são maiores. Antenas, cirros peristomiais e dorsais anteriores levemente pseudoarticulados, demais cirros dorsais e anais lisos; cirros ventrais ovais, pouco menores do que os lóbulos parapodiais. Parapódios com 2-4 acículas na região anterior, 1-2 na mediana e 1 na região posterior, todas infladas na região subdistal e afiladas distalmente (Fig. 9E). Cerdas falcígeras curtas e bidentadas, com dente distal maior do que o subdistal, e levemente espinuladas (Fig. 8B-C; 9B-C). Parapódios com 8-16 cerdas na região anterior, 4-18 na mediana e 6-7 na região posterior. Lâminas das falcígeras com pequenas variações dorso-ventral e ântero-posterior, medindo 15-5 $\mu \mathrm{m}$ nas regiões anterior e mediana, e $10-5 \mu \mathrm{m}$ na posterior. Cerdas simples dorsais 
espinuladas (Fig. 8B; 9D). Faringe ocupando 3-8 segmentos, com trépano incompleto, com 7-8 dentes na região ventral e 2 placas laterais (Fig. 9A). Proventrículo estendendo-se por 5-6 segmentos, com feixes musculares de difícil visualização.

Discussão: a espécie em questão deve ser comparada com $O$. fulgurans e $O$. guillermoi, visto que membros das três espécies apresentam cerdas falcígeras de morfologia muito semelhante.

Em relação a $O$. fulgurans, membros de ambas as espécies carecem de pigmentação corpórea, mas exemplares desta última espécie possuem os cirros dorsais da região anterior lisos, enquanto em membros de $O$. sp. 1 sp. nov. eles são pseudoarticulados. Além disso, membros de O. fulgurans possuem lóbulo nucal pequeno e arredondado em comparação com o lóbulo largo e grande observado em membros de $O$. sp. 1 sp. nov.

Tanto em indivíduos de $O$. guillermoi, quanto de $O$. sp.1 sp. nov., os lóbulos nucais alcançam a base da antena central, contudo, membros destas espécies se diferenciam pelo padrão de pigmentação observado em $O$. guillermoi, e pela morfologia dos cirros dorsais, lisos em membros de $O$. guillermoi e pseudoarticulados em $O$. sp.1 sp. nov. 
Fig. 8- Odontosyllis sp.1. A, lóbulo nucal, região anterior; $\mathbf{B}$, cerdas falcígeras, região posterior, e cerda simples dorsal, em destaque; $\mathbf{C}$, cerda falcígeras, região posterior; $\mathbf{D}$, região anterior, vista dorsal. Barras de escala: $A=50 \mu \mathrm{m} ; \mathrm{B}=10 \mu \mathrm{m} ; \mathrm{C}=2 \mu \mathrm{m} ; \mathrm{D}=30 \mu \mathrm{m}$.
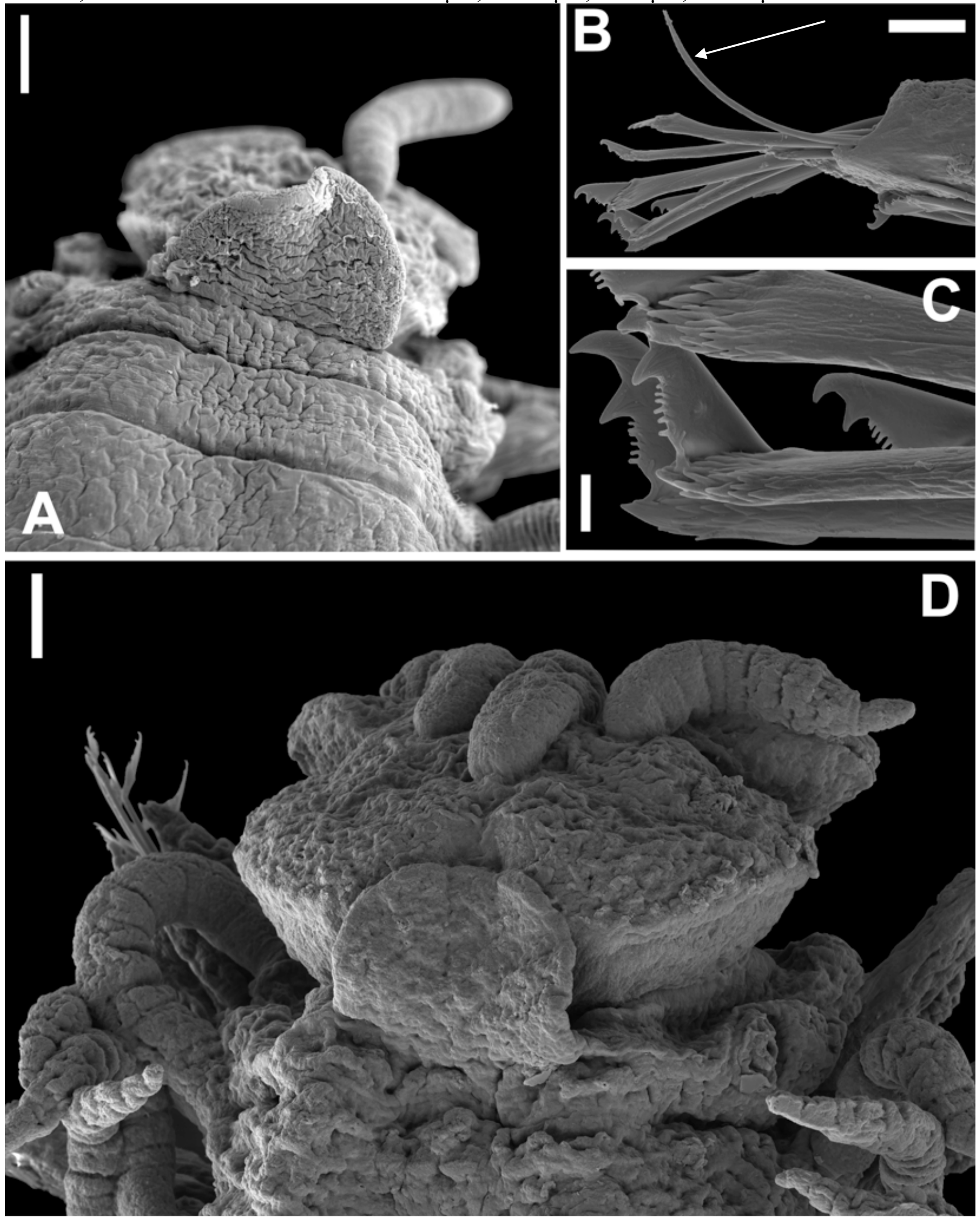

Fonte: MEV de autoria própria. 
Fig. 9- Odontosyllis sp. 1 sp. nov.. A, região anterior, vista dorsal; B, cerdas falcígeras, região anterior; $\mathbf{C}$, cerdas falcígeras, região posterior; $\mathbf{D}$, cerda simples dorsal, região posterior; $\mathbf{E}$, acículas, região anterior. Barra de escala: $\mathrm{A}=0,2 \mathrm{~mm} ; \mathrm{B}-\mathrm{E}=20 \mu \mathrm{m}$.

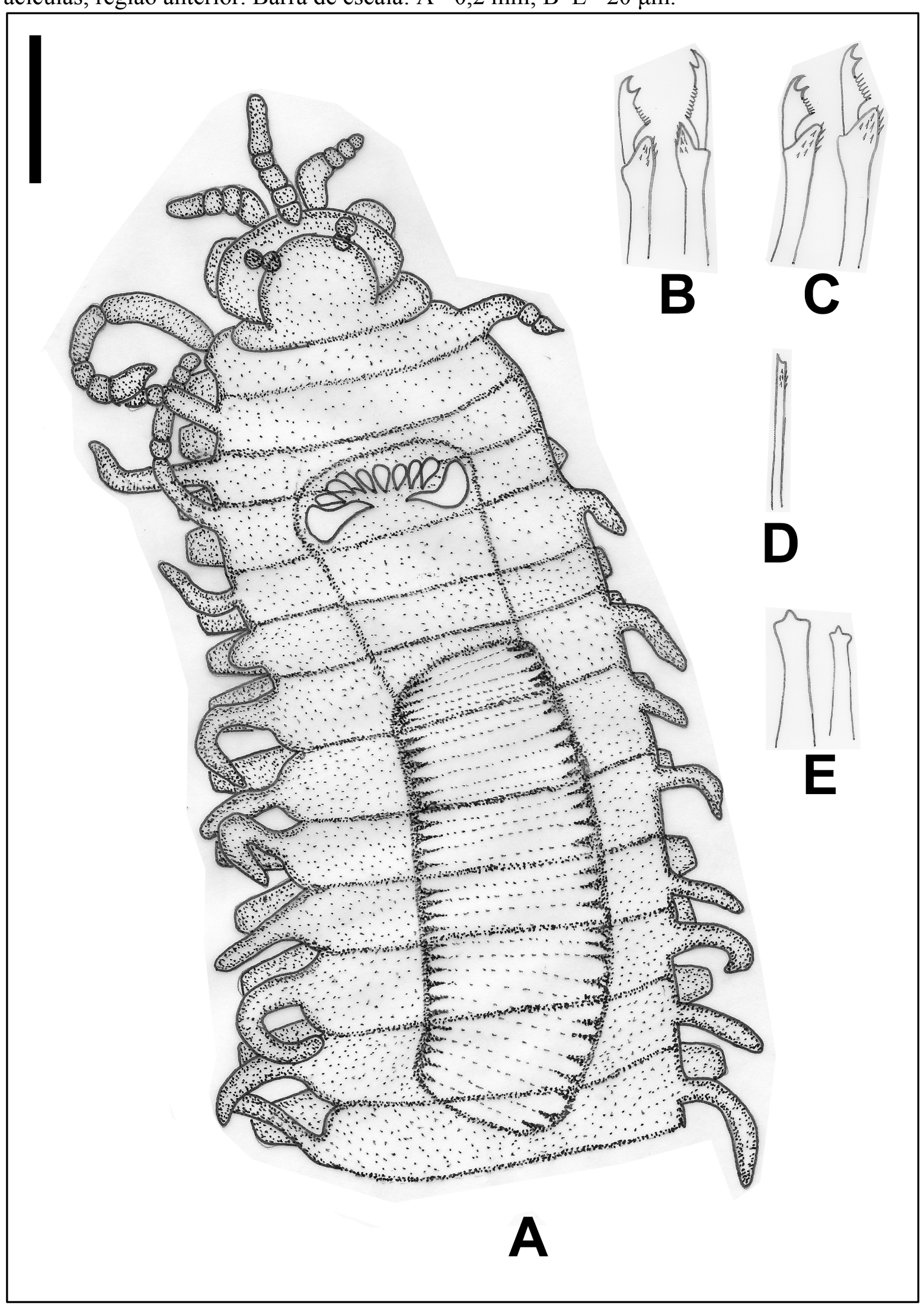

Fonte: Desenho de autoria própria. 


\section{Gênero Perkinsyllis San Martín, López \& Aguado, 2009}

Espécie-tipo: Pionosyllis longisetosa Hartmann-Schröder, 1965.

Diagnose: animais de tamanho corpóreo médio. Prostômio com 2 pares de olhos em trapézio, membros de algumas espécies também com 1 par de manchas ocelares, e 3 antenas. Peristômio com 2 pares de cirros, um dorsal e outro ventral. Antenas, cirros peristomiais e dorsais ao longo do corpo, lisos ou pseudoarticulados, dependendo da região. Cerdas compostas falcígeras presentes em todo o corpo, com espinulação característica voltada para cima, podendo haver também cerdas pseudoespinígeras. Acículas distalmente expandidas e bilobadas. Faringe com dente único, na região anterior.

Comentários: Das 10 espécies descritas para o gênero 4 possuem registros para o litoral brasileiro: P. augeneri (Hartmann-Schöder, 1979), P. biota Fukuda \& Nogueira, 2013, P. koolalya (San Martín \& Hutchings, 2006) e P. koolalyoides Fukuda \& Nogueira, 2013. Ambas as espécies presentes nesse trabalho já haviam sido registradas para a costa brasileira, mais especificamente no litoral do Rio de Janeiro e São Paulo (FUKUDA, 2010; FUKUDA \& NOGUEIRA, 2013).

\section{Chave de identificação para as espécies de Perkinsyllis encontradas neste estudo}

- Presença de cerdas pseudoespinígeras, lâminas das falcígeras medindo 15-65 $\mu \mathrm{m}$ de comprimento P. biota

- Ausência de cerdas pseudoespinígeras, lâminas das falcígeras medindo 10-25 $\mu \mathrm{m}$ de comprimento .P. koolalya 


\section{Perkinsyllis biota Fukuda \& Nogueira, 2013}

Fig. 10

Perkynsyllis biota FUKUDA \& NOGUEIRA, 2013: 983-989, figs. 5-8.

Material analisado: São Sebastião - Praia Grande, em Caulerpa lentilifera: 1 esp., 13.Dez.2015. O espécime foi encontrado incompleto. Coletado na zona entremarés.

Descrição: animal de tamanho corpóreo pequeno, com corpo subcilíndrico, com $1,25 \mathrm{~mm}$ de comprimento, incompleto, com 15 setígeros, e largura de 0,175 $\mathrm{mm}$. Corpo sem pigmentação característica. Prostômio pequeno e arredondado com 2 pares de olhos em trapézio. Palpos com aspecto triangular, fundidos na base, visíveis dorsalmente, maiores do que o prostômio. Antena mediana inserida no centro do prostômio, as laterais, com metade do comprimento da mediana, inseridas próximo à linha dos olhos anteriores. Peristômio com metade do tamanho dos segmentos, cirros peristomiais dorsais com o mesmo tamanho da antena mediana, cirros peristomiais ventrais ligeiramente menores do que os do par dorsal. Cirros dorsais com alternância de comprimento, cirros longos maiores do que a antena central, cirros curtos com 1/3 desse comprimento, com exceção dos cirros dorsais do primeiro setígero, que possuem aproximadamente o mesmo comprimento da antena mediana. Antenas, cirros peristomiais e dorsais anteriores pseudoarticulados, demais cirros dorsais e anais lisos; cirros ventrais digitiformes pouco menores do que os lóbulos parapodiais. Parapódios com 2 acículas em todo o corpo, estas podendo ser retas e pontiagudas ou bilobados na região distal, dependendo da região do corpo (Fig. 10E). Cerdas pseudoespinígeras bidentadas e espinuladas, com dente distal levemente maior. Cerdas falcígeras bidentadas, com dentes de tamanho similar na região anterior, o distal progressivamente maior em direção posterior; e levemente espinuladas, 
espinhas distais mais longas, alcançando a ponta do dente distal (Fig. 10A-B). Parapódios com 10 cerdas falcígeras e 2 pseudoespinígeras na região anterior, 6 falcígeras e 1 pseudoespinígera na região mediana. Lâminas das pseudoespinígeras medindo 37,5-32,5 $\mu \mathrm{m}$, na região anterior, e $62,5 \mu \mathrm{m}$, na região mediana. Lâminas das falcígeras com variações dorso-ventral e ânteroposterior, as da região mediana com lâminas mais longas do que as demais, medindo $27,5-12,5 \mu \mathrm{m}$ na região anterior, $32,5-12,5 \mu \mathrm{m}$ na região mediana. Cerdas simples dorsais presentes a partir da região mediana, bífidas e espinuladas (Fig. 10C); cerdas simples ventrais presentes na região mediana, bidentadas e espinuladas, com espinhas distais alcançando o nível do dente distal, este maior do que subdistal (Fig. 10D). Faringe ocupando cerca de 4 segmentos, com dente central cônico localizado na porção anterior, quase na margem. Proventrículo estendendo-se por 3 segmentos, com 26 feixes musculares.

Discussão: a espécie do gênero que mais se assemelha $P$. biota é a $P$. spinisetosa (San Martín, 1990). Membros de ambas as espécies possuem cerdas, acículas e características do proventrículo (tamanho e número de feixes musculares) similares, contudo, os de P. spinisetosa possuem cerdas simples dorsais diferentes, não apresentam olhos e seus cirros dorsais são lisos ao longo de todo o corpo, enquanto membros de $P$. biota possuem cerdas simples dorsais espinuladas, apresentam 2 pares de olhos e os cirros dorsais dos primeiros setígeros podem apresentar pseudoarticulações.

Localidade-tipo: Brasil, Rio de Janeiro, Bacia de Campos (Oceano Atlântico).

Distribuição: Da Bacia de Campos (Rio de Janeiro) a São Sebastião (São Paulo) (Oceano Atlântico). 
Fig. 10- Perkinsyllis biota. A, cerdas falcígeras e pseudoespinígera, região anterior; $\mathbf{B}$, cerdas falcígeras, região mediana; $\mathbf{C}$, cerda simples dorsal; $\mathbf{D}$, cerda simples ventral; $\mathbf{E}$, acículas da região anterior. Barra de escala: $\mathrm{A}-\mathrm{E}=20 \mu \mathrm{m}$.

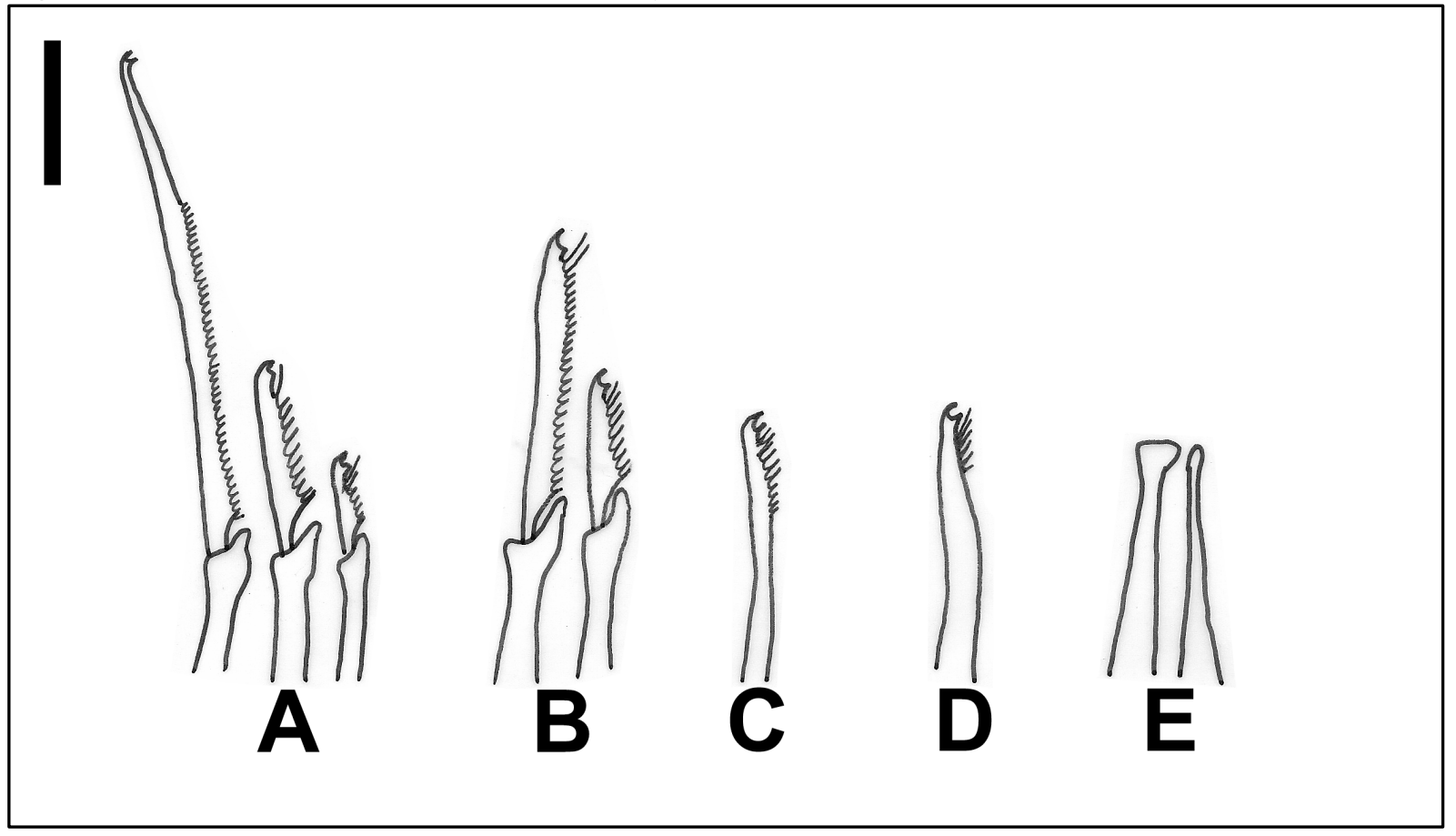

Fonte: Desenho de autoria própria.

\section{Perkinsyllis koolalya (San Martín \& Hutchings, 2006)}

Fig. 11

Pionosyllis koolalya SAN MARTÍN \& HUTCHINGS, 2006: 338-340, figs. 62A-C, 68A-P, 69A-F.

Perkinsyllis koolalya FUKUDA, 2010: 74-77, fig. 20.

Material analisado: São Sebastião - Praia da Baleia, em Caulerpa lentilifera: 1 esp., 8.Abr.2015. O espécime foi encontrado incompleto. Coletado na zona entremarés.

Descrição: animal de tamanho corpóreo pequeno, com corpo subcilíndrico, com $0,75 \mathrm{~mm}$ de comprimento, incompleto, apresentando 12 setígeros, e com largura de $0,3 \mathrm{~mm}$. Corpo sem pigmentação característica. Prostômio oval, com 2 pares de olhos em trapézio e 1 par de manchas ocelares. Palpos largos, ovalados, 
fundidos na maior parte de sua extensão, visíveis dorsalmente, maiores do que o prostômio. Antena mediana inserida na linha dos olhos posteriores, as laterais, com metade do tamanho da mediana, inseridas próximo à linha dos olhos anteriores. Peristômio com metade do tamanho dos segmentos, cirros peristomiais dorsais de mesmo tamanho da antena mediana, cirros peristomiais ventrais do tamanho das antenas laterais. Cirros dorsais com alternância de comprimento, cirros longos de mesmo comprimento da antena mediana, cirros curtos ligeiramente menores do que as antenas laterais, com exceção dos cirros do primeiro setígero, estes tão longos quanto a antena mediana. Antenas, cirros peristomiais, dorsais ao longo do corpo e anais lisos; cirros ventrais digitiformes pouco menores do que os lóbulos parapodiais. Parapódios com 2 acículas cada na região anterior, 1 acícula por parapódio a partir da região mediana (Fig. 11E). Cerdas pseudoespinígeras ausentes. Cerdas falcígeras com lâminas bidentadas, com dente distal ligeiramente maior na região anterior, diminuindo progressivamente de tamanho em direção posterior, aproximadamente de mesmo tamanho do subdistal, e levemente espinuladas, espinhas distais mais longas, alcançando o nível do dente distal (Fig. 11A-B). Parapódios com 14 cerdas falcígeras na região anterior, 6 falcígeras na região mediana. Lâminas das falcígeras com variações dorso-ventral e ântero-posterior, medindo 25-17,5 $\mu \mathrm{m}$ na região anterior, $22,5-10 \mu \mathrm{m}$ na região mediana. Cerdas simples dorsais presentes a partir da região mediana, bífidas e espinuladas (Fig. 11C); cerdas simples ventrais presentes apenas na região posterior, bidentadas e espinuladas, com espinhas distais alcançando o nível do dente distal, este do mesmo tamanho do subdistal (Fig. 11D). Faringe ocupando cerca de 4 segmentos, com dente central cônico, localizado na porção anterior, quase na margem. Proventrículo estendendo-se por 6 segmentos, com 30 feixes musculares.

Discussão: membros desta espécie se assemelham muito aos de $P$. serrata (Hartmann-Schöder, 1984) pela morfologia de suas cerdas e pela ausência de cerdas pseudoespinígeras, contudo eles se diferenciam, pois, $P$. serrata 
apresenta falcígeras modificadas, sendo estas mais curtas e engrossadas, e mais acículas por parapódio, na região anterior, tendo $P$. serrata até 3 acículas, enquanto $P$. koolalya possui no máximo 2 acículas.

Localidade-tipo: Austrália, Streeky Bay, Speeds Point (Oceano Índico).

Distribuição: Austrália (Oceano Índico); Austrália (Oceano Pacífico); São Sebastião, São Paulo - Brasil (Oceano Atlântico).

Fig. 11 - Perkinsyllis koolalya. A, cerdas falcígeras, região anterior; $\mathbf{B}$, cerdas falcígeras, região mediana; $\mathbf{C}$, cerda simples dorsal; $\mathbf{D}$, cerda simples ventral; $\mathbf{E}$, acículas da região anterior. Barra de escala: A-E $=20 \mu \mathrm{m}$.

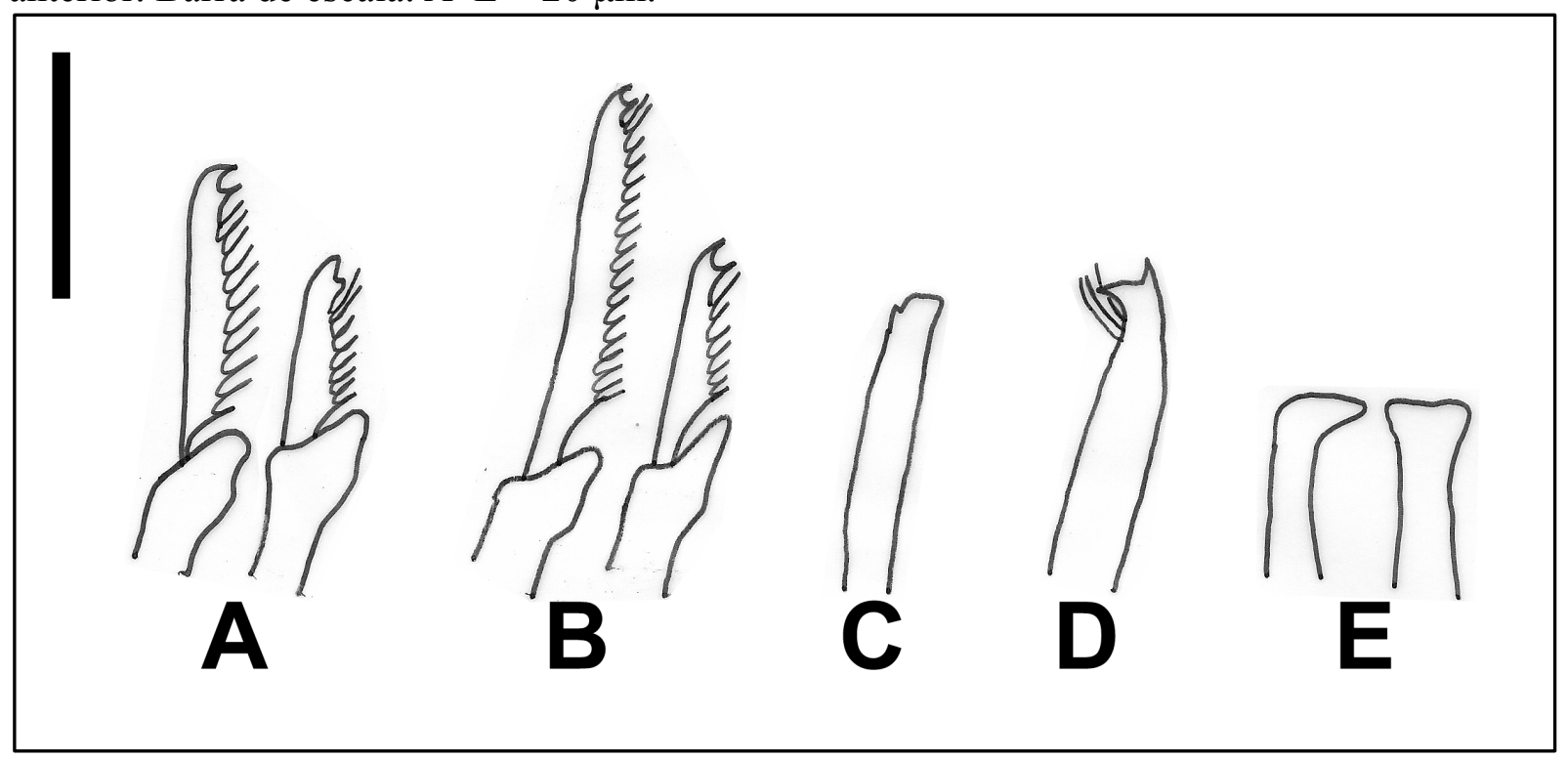

Fonte: Desenho de autoria própria.

\section{Subfamília Exogoninae Langerhans, 1879}

Diagnose: animais de porte pequeno, corpo subcilíndrico, palpos fundidos em sua totalidade, ou praticamente. Prostômio com 2 pares de olhos, frequentemente também com 1 par de manchas ocelares, e 3 antenas. Antenas, cirros peristomiais e dorsais ao longo do corpo curtos, lisos, subulados a papiliformes. Incubação dorsal de ovos, ou ventral de embriões.

Comentários: membros desta subfamília são de fácil reconhecimento, devido à fusão dos palpos e à morfologia de suas antenas e cirros peristomiais, dorsais ao 
longo do corpo e anais. Os métodos de incubação de ovos ou embriões são característicos para cada gênero.

\section{Chave de identificação para os gêneros de Exogoninae neste estudo}

1a. Cirros peristomiais diminutos; cirros dorsais pequenos e papiliformes; acículas distalmente infladas; falcígeras com lâminas bidentadas, com dente subdistal maior do que o distal, este praticamente inconspícuo; corpo não

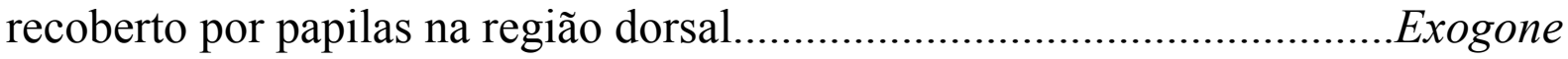
1b. Cirros peristomiais e dorsais ao longo do corpo subulados; acículas dobradas em ângulo reto ou levemente oblíquas; falcígeras de morfologia distinta, com lâminas bidentadas; corpo geralmente recoberto de papilas na região dorsal

2a. (1b) Proventrículo curto, com poucas fileiras de feixes musculares; acículas dobradas em ângulo reto. Sphaerosyllis

2b. Proventrículo grande, com numerosas fileiras musculares; acículas com fina ponta oblíqua Erinaceusyllis

\section{Gênero Erinaceusyllis San Martín, 2005}

Espécie-tipo: Sphaerosyllis erinaceus Claparède, 1863.

Diagnose: animais de tamanho corpóreo pequeno, subcilíndricos e normalmente recobertos de papilas. Palpos arredondados, mais largos do que longos. Prostômio com 2 pares de olhos, 1 par de manchas ocelares e 3 antenas. Peristômio com 1 par de cirros peristomiais, similares aos cirros dorsais; Antenas, cirros peristomiais, dorsais ao longo do corpo e anais globosos na base e afilando na direção apical, subulados, com exceção do segundo setígero onde 
os cirros não há cirros dorsais. Falcígeras com lâminas uni- e/ou bidentadas, variando em tamanho, mas em geral finas e longas. Acículas subdistalmente infladas, com ponta oblíqua. Faringe com dente nas proximidades da margem anterior. Proventrículo com numerosas fileiras musculares. Apesar de não ter sido observada neste estudo, sabe-se que este gênero apresenta incubação dorsal de ovos (SAN MARTÍN, 2003; FUKUDA, 2010).

Comentários: o gênero possui 12 espécies válidas, cinco das quais já registradas para o litoral brasileiro: E. belizensis (Russell, 1989), E. bilobata (Perkins, 1981), E. centroamericana (Hartmann-Schröder, 1959) E. perkinsi (Riser,1991) e E. subterranea (Hartmann-Schröder,1960).

\section{Chave de identificação para as espécies de Erinaceusyllis encontradas neste estudo}

1a. Presença de cerdas falcígeras com lâminas bidentadas E. bilobata

1b. Todas as cerdas falcígeras com lâminas unidentadas .2

2a. (1b) Cirros com base arredondada e extremidade afilada, sem nenhuma especialização adicional.

E. perkinsi

2b. Cirros com base arredondada e com ponta modificada em estrutura globular E. sp.1 sp. nov.

\section{Erinaceusyllis bilobata (Perkins, 1981)}

Fig. 12

Sphaerosyllis bilobata NOGUEIRA, 2000: 50, fig. 11.

Erinaceusyllis bilobata FUKUDA, 2010: 98-100, fig. 26. 
Material analisado: São Sebastião - Praia Grande, em Caulerpa lentilifera: 3 esp., 30.Jun.2015. Coletados na zona entremarés.

Descrição: animais de tamanho corpóreo pequeno, com corpo subcilíndrico, com $1 \mathrm{~mm}$ de comprimento em todos os exemplares, apresentando de 18-27 setígeros, e com largura de $0,1-0,15 \mathrm{~mm}$. Corpo sem pigmentação. Prostômio retangular, com 2 pares de olhos quase em linha e 1 par de manchas ocelares. Palpos mais largos do que compridos, fundidos em toda sua extensão, visíveis dorsalmente. Antena mediana inserida próxima à linha dos olhos, as laterais com $3 / 4$ do tamanho da mediana, inseridas próximo à margem anterior do prostômio. Peristômio com mesmo tamanho dos segmentos, cirros peristomiais com $2 / 3$ do tamanho das antenas laterais. Cirros dorsais ao longo do corpo do mesmo tamanho dos cirros peristomiais, ausentes no setígero 2. Antenas, cirros peristomiais, dorsais ao longo do corpo e anais subulados, semelhantes a garrafas ou pinos de boliche, com base bulbosa e ponta distalmente arredondada; cirros ventrais digitiformes, pouco menores do que os lóbulos parapodiais. Parapódios com 1 acícula cada em todo o corpo (Fig. 12E). Cerdas falcígeras bidentadas, com dente distal ligeiramente maior na região anterior, dente subdistal progressivamente maior, em direção posterior, alcançando aproximadamente o mesmo tamnho do dente distal, nos últimos segmentos; falcígeras superiores (dorsais) levemente espinuladas (Fig. 12A-B). Parapódios com 6-10 cerdas falcígeras na região anterior, 6-9 na mediana e 6-8 na região posterior. Lâminas das falcígeras com variações dorso-ventral e ânteroposterior, medindo $27,5-10 \mu \mathrm{m}$ na região anterior, $22,5-7,5 \mu \mathrm{m}$ na mediana e 17,5-5 $\mu \mathrm{m}$ na posterior. Cerdas simples dorsais presentes em todos os parapódios, lisas, subdistalmente infladas e distalmente afiladas (Fig. 12C); cerdas simples ventrais presentes apenas na região posterior, sub-bidentadas e lisas, com dente subdistal extremamente fino e praticamente inconspícuo (Fig. 12D). Faringe ocupando de 4-5 segmentos, com dente central cônico, localizado 
na porção anterior, quase na abertura. Proventrículo estendendo-se por 4 segmentos, com 14-16 feixes musculares.

Discussão: a espécie do gênero que mais se assemelha a $E$. bilobata é $E$. cryptica (Ben-Eliahu, 1977), sendo estas praticamente idênticas, ambas aceitas como válidas apenas pela distribuição, sendo E. cryptica uma espécie europeia e E. bilobata, americana (SAN MARTÍN, 2003). As características que as diferenciam estão associadas às lâminas de suas falcígeras. Membros de $E$. cryptica apresentam falcígeras com dente subdistal pequeno e fino, similar a uma espinha, e os dentes são muito próximos entre si. Já os exemplares de $E$. bilobata possuem dente subdistal mais robusto, com espaço entre os dentes progressivamente maior tanto em direção ventral em cada parapódio, quanto em região posterior, ao longo do corpo.

Localidade-tipo: EUA, Ilha Hutchingson (Oceano Atlântico).

Distribuição: Da Flórida ao Estado de São Paulo (Oceano Atlântico).

Fig. 12 - Erinaceusyllis bilobata. A, cerdas falcígeras, região anterior; $\mathbf{B}$, cerdas falcígeras, região posterior; $\mathbf{C}$, cerda simples dorsal; $\mathbf{D}$, cerda simples ventral; $\mathbf{E}$, acícula da região anterior. Barra de escala: A-E $=20 \mu \mathrm{m}$.

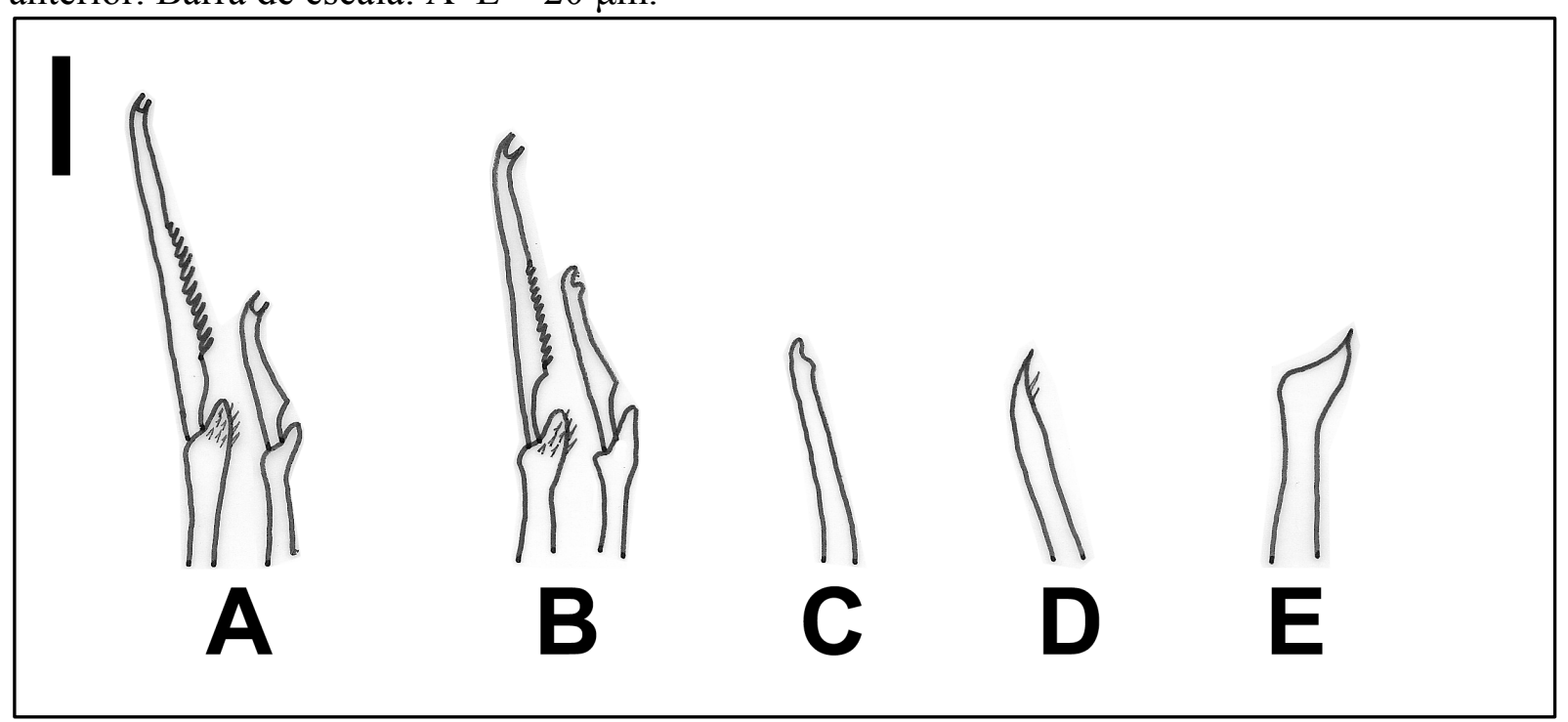

Fonte: Desenho de autoria própria. 


\section{Erinaceusyllis perkinsi (Riser, 1991)}

Fig. 13

Erinaceusyllis perkinsi FUKUDA, 2010: 103-106, fig. 28.

Material analisado: São Sebastião - Praia Grande, em Caulerpa lentilifera: 2 esp., 30.Jun.2015. Coletados na zona entremarés.

Descrição: animais de tamanho corpóreo pequeno, com corpo subcilíndrico, com $0,875-1,125 \mathrm{~mm}$ de comprimento, apresentando entre $22-24$ setígeros, e com largura entre $0,1-0,125 \mathrm{~mm}$. Corpo sem pigmentação característica, mas recoberto por algumas papilas "mamiliformes", de tamanhos variados. Prostômio retangular com 2 pares de olhos quase em linha e 1 par de manchas ocelares. Palpos largos e curtos, fundidos em toda sua extensão, visíveis dorsalmente. Antena mediana inserida na linha dos olhos, antenas laterais com metade do tamanho da mediana, inseridas próximo à linha dos olhos, anteriores em relação à mediana. Peristômio com metade do tamanho dos segmentos, com cirros peristomiais ligeiramente menores do que as antenas laterais. Antenas, cirros peristomiais, dorsais ao longo do corpo e anais subulados, similares a garrafas ou pinos de boliche, com base bulbosa e ponta distalmente arredondada, ausentes no segundo setígero; cirros ventrais digitiformes, pouco menores do que os lóbulos parapodiais. Parapódios com 1 acícula cada em todo o corpo (Fig. 13E). Cerdas falcígeras com lâminas unidentadas e espinuladas, as mais dorsais, ou lisas, as ventrais (Fig. 13A-B). Parapódios com 9 cerdas falcígeras na região anterior, 6-7 na mediana e 5-6 na posterior. Lâminas das falcígeras com variações dorso-ventral e ântero-posterior, medindo $20-10 \mu \mathrm{m}$ na região anterior, $15-10 \mu \mathrm{m}$ na mediana e $12,5-5 \mu \mathrm{m}$ na posterior. Cerdas simples dorsais presentes em todos os parapódios, sigmoides e unidentadas, com leve espinulação subdistal (Fig. 13C); cerdas simples ventrais presentes apenas na 
região posterior, também sigmoides, mas lisas (Fig. 13D). Faringe ocupando cerca de 3-4 segmentos, com dente central cônico, localizado na porção anterior, quase na abertura. Proventrículo estendendo-se por 3-4 segmentos, com 14-15 feixes musculares.

Discussão: a espécie do gênero cujos exemplares mais se assemelham aos de $E$. perkinsi é E. labyrintophila (Gardiner \& Wilson, 1979), com cerdas, acículas e tamanho do proventrículo muito semelhantes. Contudo, o comprimento das antenas é diferente em E. labyrintophila as antenas são conspicuamente maiores, principalmente a mediana, e as lâminas das falcígeras são mais compridas chegando a até $30 \mu \mathrm{m}$.

Localidade-tipo: EUA, Massachusetts (Oceano Atlânico).

Distribuição: Costa leste dos EUA; Brasil (Oceano Atlântico).

Fig. 13 - Erinaceusyllis perkinsi. A, cerdas falcígeras, região anterior; $\mathbf{B}$, cerdas falcígeras, região posterior; $\mathbf{C}$, cerda simples dorsal; $\mathbf{D}$, cerda simples ventral; $\mathbf{E}$, acícula da região anterior. Barra de escala: A-E $=100 \mu \mathrm{m}$.

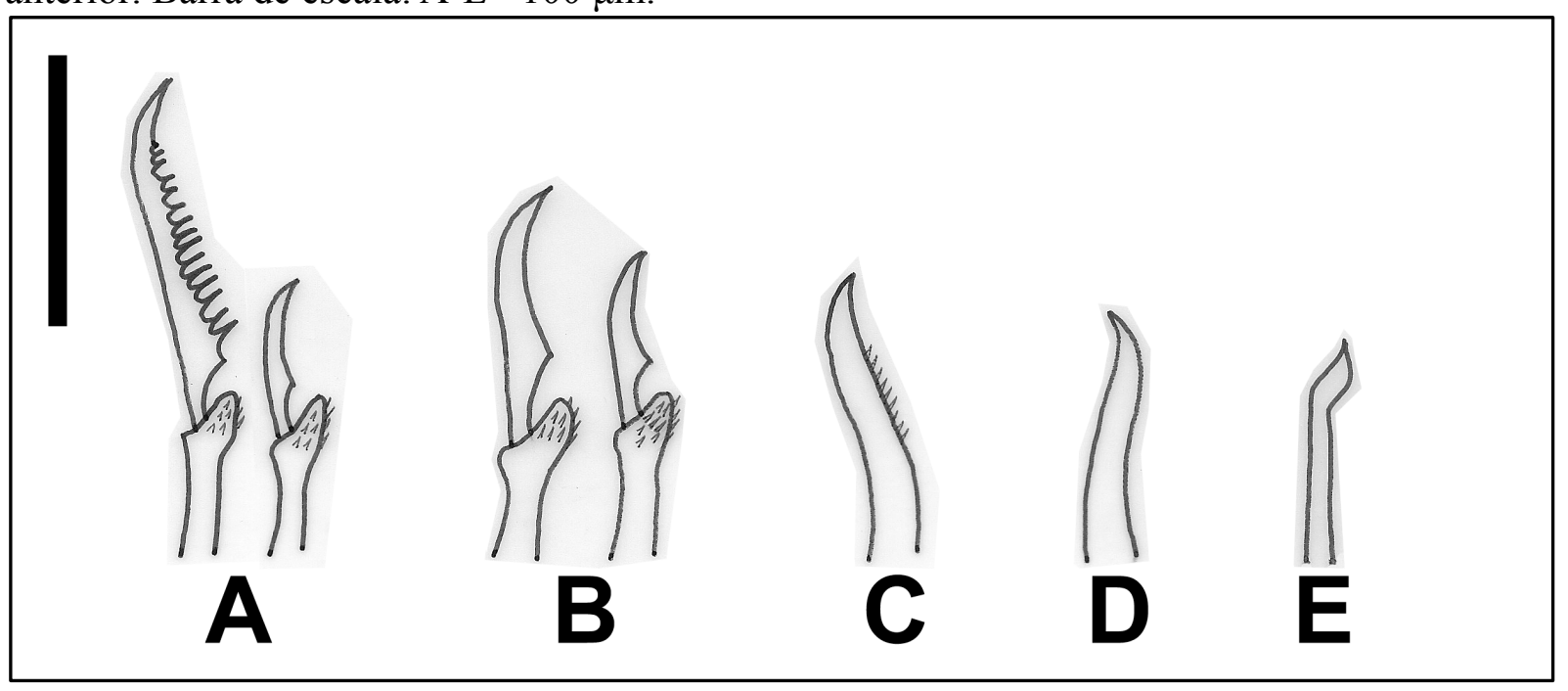

Fonte: Desenho de autoria própria.

Erinaceusyllis sp. 1 sp. nov.

Fig. 14, 15

Material analisado: São Sebastião - Praia Grande, em Caulerpa lentilifera: 1 
esp., 30.Jun.2015. Coletado na zona entremarés.

Descrição: animal de tamanho corpóreo pequeno, com corpo subcilíndrico, com 0,75 $\mathrm{mm}$ de comprimento, apresentando 15 setígeros, e com largura de 0,125 mm. Corpo sem pigmentação característica, mas com inclusões iridescentes no tegumento e recoberto quase inteiramente por papilas "mamiliformes", de tamanhos variados. Prostômio retangular com 2 pares de olhos quase em linha e 1 par de manchas ocelares (Fig. 15A,C). Palpos largos e curtos, fundidos em toda sua extensão, visíveis dorsalmente. Antena mediana inserida na linha dos olhos, antenas laterais com metade do tamanho da mediana, inseridas próximo à linha dos olhos, anteriores em relação à mediana. Peristômio com metade do tamanho dos segmentos, com cirros peristomiais ligeiramente menores do que as antenas laterais. Antenas, cirros peristomiais e anais subulados, similares a garrafas ou pinos de boliche, com base bulbosa e ponta afilada; cirros dorsais similares, mas com extremidade globular, aparentemente retrátil, ausentes no segundo setígero (Fig. 14A; 15B); cirros ventrais digitiformes, pouco menores do que os lóbulos parapodiais. Parapódios com 2 acículas cada na região anterior, 1 acícula por parapódio a partir dos segmentos medianos (Fig. 14D). Cerdas falcígeras com lâminas unidentadas e lisas (Fig. 14B-C). Parapódios com 10 cerdas falcígeras na região anterior, 8 na mediana e 6 na posterior. Lâminas das falcígeras com variações dorso-ventral e ântero-posterior, medindo 20-10 $\mu \mathrm{m}$ na região anterior, $15-7,5 \mu \mathrm{m}$ na mediana e $10-5 \mu \mathrm{m}$ na região posterior. Cerdas simples dorsais presentes em todos os parapódios, sigmoides, unidentadas com leve espinulação subdistal; cerdas simples ventrais presentes apenas na região posterior, também sigmoides, mas lisas (Fig. 14E-F). Faringe ocupando cerca de 5 segmentos, com dente central cônico, localizado na porção anterior, quase na margem. Proventrículo estendendo-se por 4 segmentos, com 19 feixes musculares.

Discussão: este espécime se assemelha muito a membros de E. bilobata e $E$. 
perkinsi, contudo algumas características o diferenciam deles, como a espinulação nas cerdas falcígeras, que está presente em membros de ambas as espécies citadas, mas ausente neste animal; além disso, o tegumento deste animal apresenta grânulos internos iridescentes, que não podemos observar nos outros. A característica mais marcante desta espécie é a morfologia dos apêndices, as antenas, cirros peristomiais e dorsais ao longo do corpo; assim como nas demais espécies do gênero, os apêndices são subulados, contudo, neste exemplar, os apêndices terminam por uma ponta esférica, aparentemente retrátil, lembrando aqueles de Prosphaerosyllis San Martín, 1984.

Fig. 14 - Erinaceusyllis sp.1 sp. nov. A, região anterior, vista dorsal; B, cerdas falcígeras, região anterior; $\mathbf{C}$, cerdas falcígeras, região posterior; $\mathbf{D}$, acícula da região anterior; $\mathbf{E}$, cerda simples dorsal, região posterior; $\mathbf{F}$, cerda simples ventral, região posterior. Barra de escala: A $=50 \mu \mathrm{m} ; \mathrm{B}-\mathrm{F}=20 \mu \mathrm{m}$.

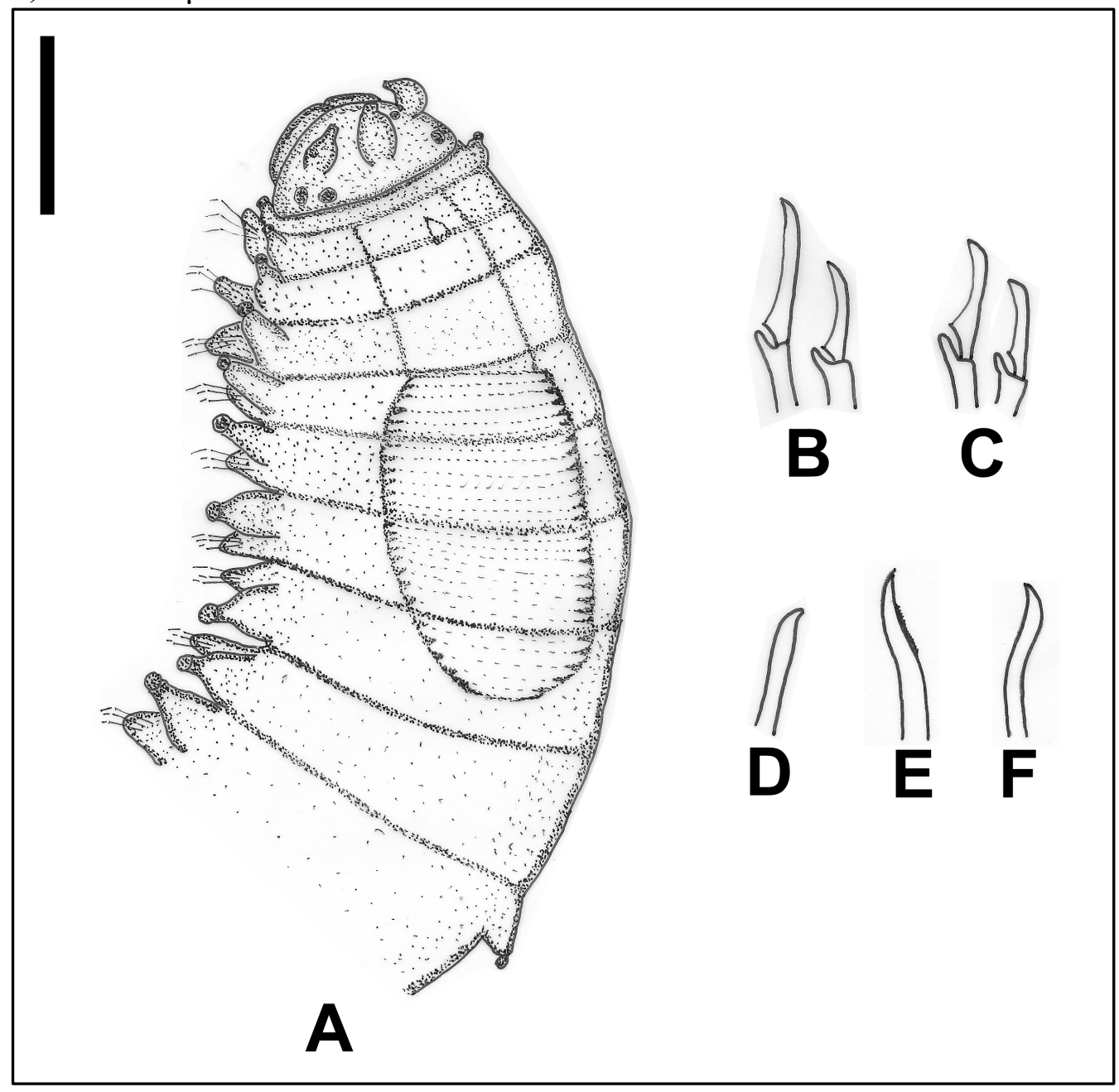

Fonte: Desenho de autoria própria. 
Fig. 15 - Erinaceusyllis sp.1 sp. nov. A, região anterior, vista dorsal; B, cirros dorsais, região mediana; $\mathbf{C}$, corpo inteiro, vista dorsal. Barra de escala: $\mathrm{A}=0,1 \mathrm{~mm} ; \mathrm{B}=50 \mu \mathrm{m} ; \mathrm{C}=0,2 \mathrm{~mm}$.

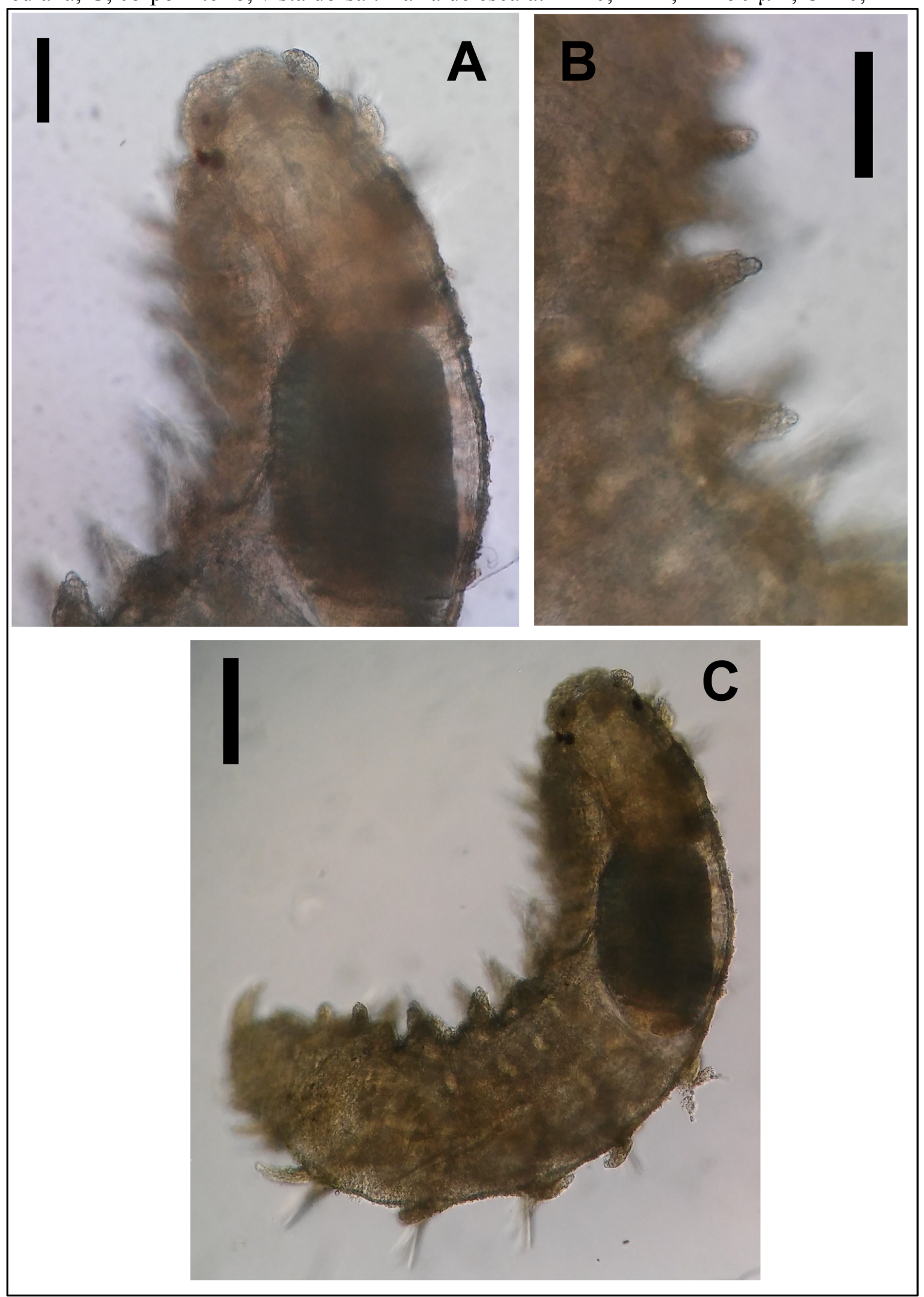

Fonte: Fotografia de autoria própria. 


\section{Gênero Exogone Örsted, 1845}

Espécie-tipo: Exogone naidina Örsted, 1845.

Diagnose: animais de tamanho corpóreo pequeno. Prostômio pequeno e ovalado, com 2 pares de olhos e, frequentemente, 1 par de manchas ocelares; 3 antenas lisas, ovaladas a digitiformes, a mediana frequentemente mais longa, podendo ultrapassar o nível da extremidade dos palpos. Peristômio curto, com 1 par de cirros peristomiais diminutos. Cirros peristomiais, dorsais e ventrais ao longo do corpo, diminutos e papiliformes, os ventrais por vezes apenas ligeiramente menores do que os dorsais; cirros dorsais presentes em todos os setígeros. Cerdas compostas falcígeras e, frequentemente, pseudoespinígeras; espinulação presente; lâminas das falcígeras bidentadas, com dente distal menor do que o subdistal, por vezes inconspícuos. Cerdas simples dorsais presentes em todos os parapódios, espinuladas, com ponta em baioneta, progressivamente mais robustas em direção posterior. Acículas distalmente infladas e recurvadas, na maioria dos casos. Incubação ventral de ovos.

Comentários: atualmente, são conhecidas aproximadamente 80 espécies para o gênero. Dessas, 20 espécies já foram registradas no litoral brasileiro (AMARAL et al., 2013), incluindo as 3 descritas encontradas neste estudo, E. africana Hartmann-Schöder, 1974, E. breviantennata Hartmann-Schöder, 1959 e E. lourei (Berkeley \& Berkeley, 1938).

\section{Chave de identificação para as espécies de Exogone neste estudo}

1a. Antena central com, no mínimo, o dobro do comprimento das laterais

E. lourei 
1b. Todas as antenas aproximadamente de mesmo tamanho, curtas e papiliformes

2a. (1b) Proventrículo ocupando 3,5-4 segmentos. Falcígeras da região anterior com lâminas com muitas espinhas marginais finas

E. africana

2b. Proventrículo ocupando 1,5-2,5 segmentos. Falcígeras da região anterior com poucas espinhas marginais robustas.

E. breviantennata

\section{Exogone africana Hartmann-Schröder, 1974}

Fig. 16

Exogone (Exogone) africana SAN MARTÍN, 2005: 143-145, figs. 90-91; FUKUDA, 2010: 112-115, fig. 30 .

Material analisado: São Sebastião - Praia da Baleia, em Caulerpa lentilifera: 2 esp., 08.Abr.2016; Praia da Baleia, em Dyctiota ciliolata: 16 esp., 08.Abr.2016; Praia Grande, em Caulerpa lentilifera: 9 esp., 30.Jun.2015. Todos os indivíduos foram coletados na zona entremarés.

Descrição. animais de tamanho corpóreo mediano, com corpo subcilíndrico, com 0,875-2,875 $\mathrm{mm}$ de comprimento, apresentando 14-42 setígeros, e com largura de $0,175-0,225 \mathrm{~mm}$. Prostômio pequeno e ovalado, com 2 pares de olhos em trapézio. Palpos completamente fundidos, com formato triangular, levemente arredondados na ponta. Antena mediana inserida na linha dos olhos anteriores, antenas laterais ligeiramente menores do que a central, inseridas próximas à mesma, a cada lado dela. Peristômio com metade do tamanho dos segmentos, com cirros peristomiais ligeiramente menores do que os cirros dorsais. Antenas, cirros dorsais e peristomiais similares, papiliformes e pequenos; cirros ventrais digitiformes, consideravelmente menores do que os lóbulos parapodiais. Parapódios com 2 acículas cada na região anterior, 1 
acícula por parapódio a partir dos segmentos medianos (Fig. 16E). Cerdas falcígeras bidentadas e espinuladas, dente distal praticamente inconspícuo, cerdas pseudoespinígeras presentes (Fig. 16A-B). Parapódios com 3-5 cerdas falcígeras e 1-2 pseudoespinígeras cada, na região anterior, 3-5 falcígeras e 1 pseudoespinígera na mediana, e 2-4 falcígeras e 1 pseudoespinígera na posterior. Lâminas das pseudoespinígeras e falcígeras com variações dorsoventral e ântero-posterior, as das pseudoespinígeras medindo 37,5-12,5 $\mu \mathrm{m}$ na região anterior, 32,5-10 $\mu \mathrm{m}$ na mediana e $25-10 \mu \mathrm{m}$ na posterior; lâminas das falcígeras medindo 7,5-5 $\mu \mathrm{m}$ na região anterior e aproximadamente $5 \mu \mathrm{m}$ nas demais regiões do corpo. Cerdas simples dorsais presentes em todos os parapódios, com ponta arredondada oblíqua e leve espinulação subdistal (Fig. 16C); cerdas simples ventrais bidentadas, presentes apenas na região posterior, com dente subdistal maior do que o distal (Fig. 16D). Faringe ocupando cerca de 4-6 segmentos, com dente central fino, localizado na porção anterior, quase na margem. Proventrículo estendendo-se por 3-6 segmentos, com 26-28 feixes musculares.

Discussão: exemplares desta espécie se assemelham muito a membros de $E$. breviantennata, em relação à morfologia das antenas e cirros, bem como na morfologia e número de cerdas falcígeras por parapódio. Os pontos que acabam diferenciando os membros destas espécies são o tamanho do proventrículo e padrão de espinulação das cerdas falcígeras. No caso de membros de $E$. africana, o proventrículo ocupa 3,5-5 segmentos e as cerdas falcígeras apresentam uma espinulação fina e numerosa, em contrapartida, exemplares de E. breviantennata apresentam proventrículo que ocupa de 2-3 segmentos e suas falcígeras possuem uma espinulação mais robusta, com menos espinhas.

Distribuição: Namíbia, Angola e Brazil (Oceano Atlântico). Havaí, Japão e Austrália (Oceano Pacífico). Austrália (Oceano Índico). 
Fig. 16 - Exogone africana. A, cerdas pseudoespinígera e falcígera, região anterior; B, cerdas pseudoespinígera e falcígera, região posterior; $\mathbf{C}$, cerdas simples dorsais, segmentos anterior e posterior, da esquerda para a direita; D, cerda simples ventral; E, acículas da região anterior. Barra de escala: A-E $=10 \mu \mathrm{m}$.

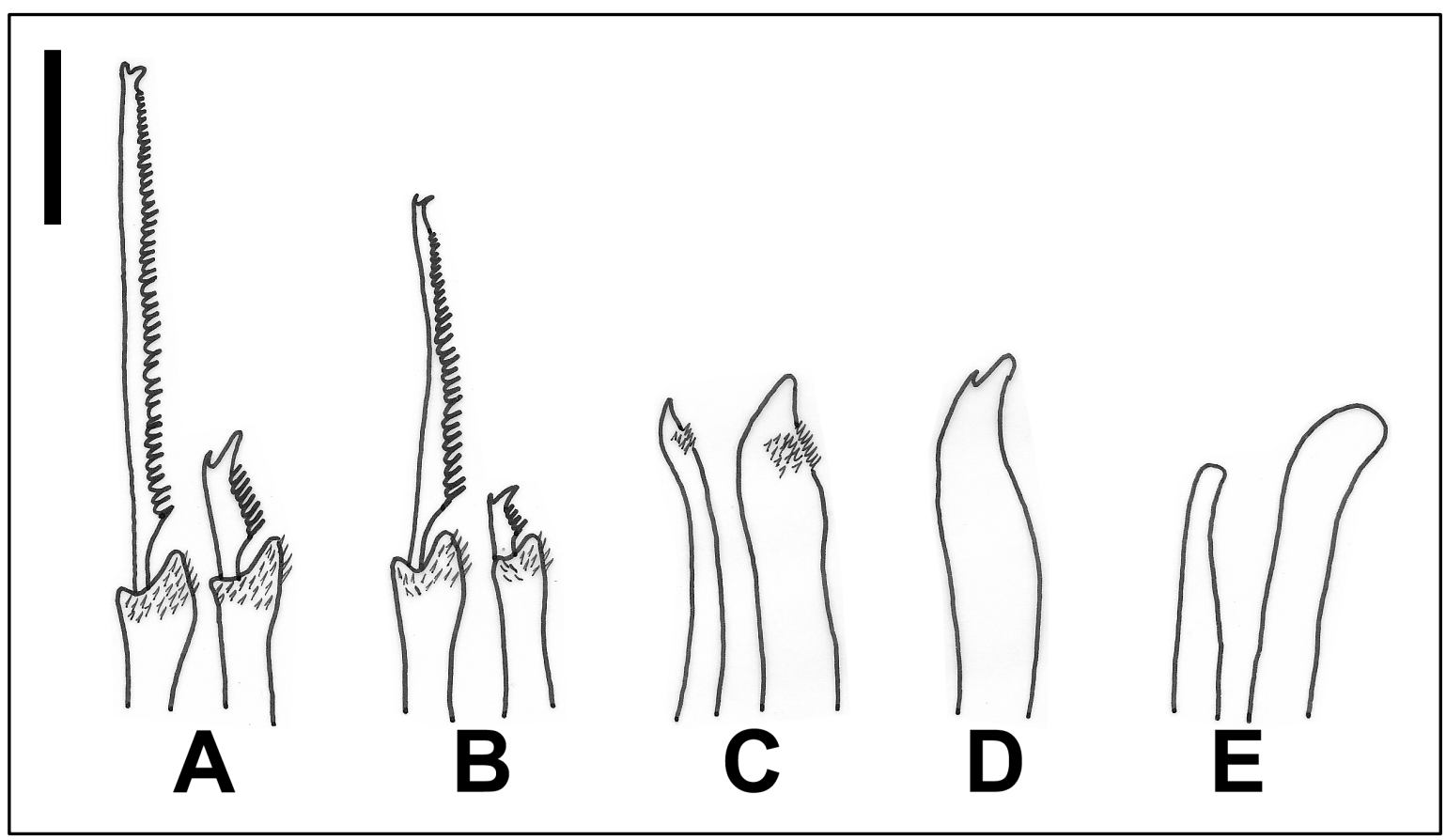

Fonte: Desenho de autoria própria.

\section{Exogone breviantennata Hartmann-Schröder, 1959}

Fig. 17

Exogone (Exogone) breviantennata NOGUEIRA, 2000: 32, fig. 6F-I; NOGUEIRA et al., 2004: 63-66, figs. 6-7; FUKUDA, 2010: 121-125, figs. 33-34.

Material analisado: São Sebastião - Praia Grande, em Caulerpa lentilifera: 2 esp., 13.Dez.2015; Praia Grande, em Hypnea musciform: 15 esp., 13.Dez.2015; Praia da Baleia, em Dyctiota ciliolata: 1 esp., 08.Abr.2015; Praia Grande, em Caulerpa lentilifera: 5 esp., 30.Jun.2015. Todos os indivíduos foram coletados na zona entremarés.

Descrição: animais de tamanho corpóreo pequeno a médio, com corpo subcilíndrico fino e alongado, com $0,5-3,625 \mathrm{~mm}$ de comprimento, 
apresentando de 10-30 setígeros, e com largura de 0,25-1 mm. Prostômio curto e arredondado com 2 pares de olhos em trapézio, manchas ocelares ausentes. Palpos fundidos em praticamente toda sua extensão, visíveis dorsalmente. Antenas mediana e laterais inseridas próximo à linha dos olhos anteriores, todas diminutas, as laterais ligeiramente menores do que a mediana. Peristômio com metade do tamanho dos segmentos, cirros peristomiais ligeiramente menores do que as antenas laterais. Antenas, cirros peristomiais e dorsais ao longo do corpo papiliformes; cirros ventrais digitiformes, pouco menores do que os dorsais. Parapódios com 2 acículas cada na região anterior, 1 acícula por parapódio a partir dos segmentos medianos (Fig. 17E). Cerdas falcígeras bidentadas e espinuladas, dente distal praticamente inconspícuo, cerdas pseudoespinígeras presentes (Fig. 17A-B). Parapódios com 5-6 cerdas falcígeras e 1-2 pseudoespinígeras na região anterior, 4-5 falcígeras e 1 pseudoespinígera na mediana, e 3-4 falcígeras e 1 pseudoespinígera na posterior. Lâminas das pseudoespinígeras e falcígeras com variações dorso-ventral e ântero-posterior, medindo $35-12,5 \mu \mathrm{m}$ e 7,5-5 $\mu \mathrm{m}$ na região anterior, respectivamente, $22,5-10$ $\mu \mathrm{m}$ e $5 \mu \mathrm{m}$ na mediana, e $15-7,5 \mu \mathrm{m}$ e $5-2,5 \mu \mathrm{m}$ na posterior. Cerdas simples dorsais presentes em todos os parapódios, com leve espinulação subdistal, cerdas progressivamente mais robustas em direção posterior (Fig. 17C); cerdas simples ventrais bidentadas, presentes apenas na região posterior, com dente subdistal maior do que o distal (Fig. 17D). Faringe ocupando cerca de 3-5 segmentos, com dente central fino, localizado na porção anterior, quase na margem. Proventrículo estendendo-se por 2-3 segmentos, com 15-21 feixes musculares.

Discussão: a espécie do gênero com a qual os membros de $E$. breviantennata mais se assemelham é E. africana podendo ser diferenciados a partir do tamanho do proventrículo e da espinulação nas falcígeras, conforme discutido acima (Ver "Discussão" na espécie E. africana).

Localidade-tipo: El Salvador (Oceano Pacífico). 
Distribuição: Espécie circumtropical.

Fig. 17 - Exogone breviantennata. A, cerdas pseudoespinígera e falcígera, região anterior; B, cerdas pseudoespinígera e falcígera, região posterior; C, cerda simples dorsal, região posterior; D, cerda simples ventral, região posterior; E, acículas da região anterior. Barra de escala: $\mathrm{A}-\mathrm{E}=10 \mu \mathrm{m}$.

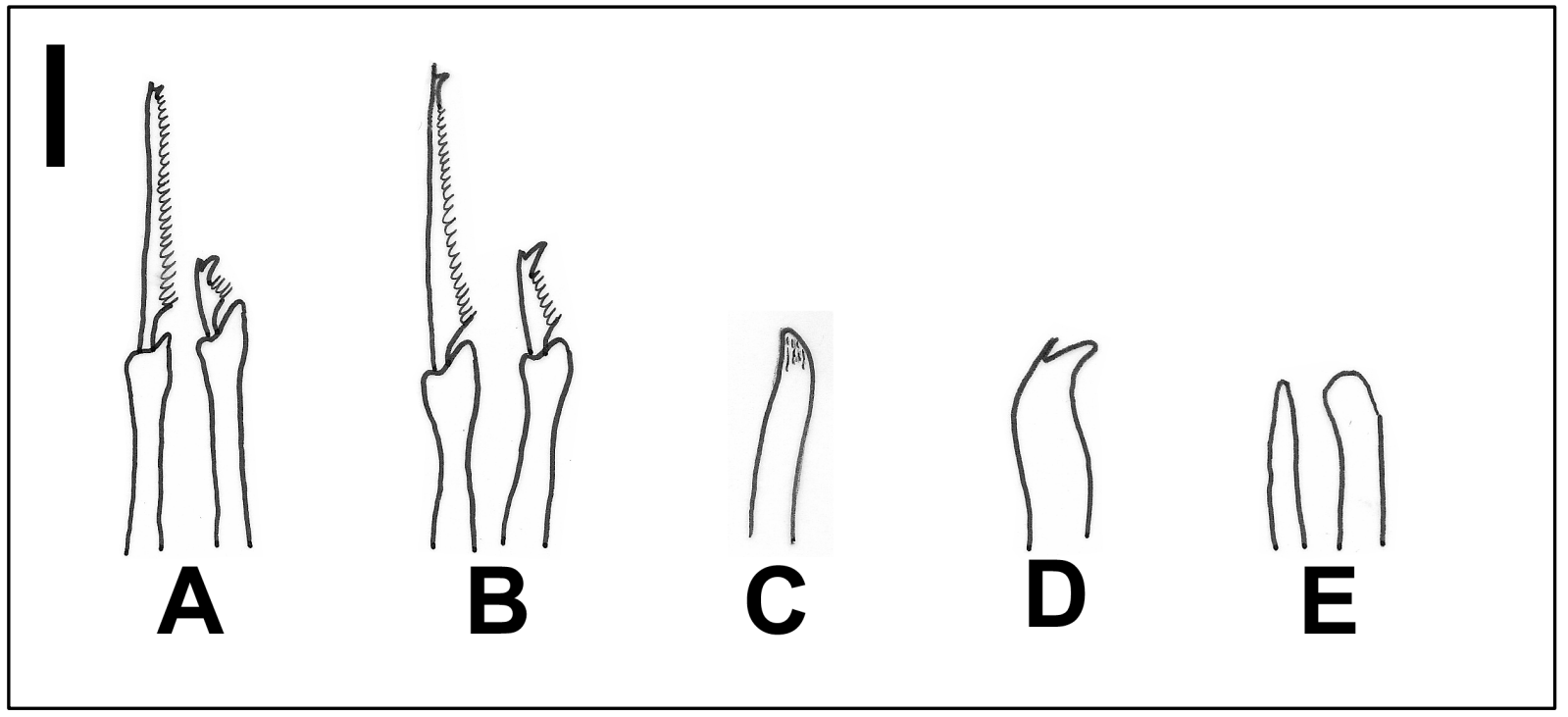

Fonte: Desenho de autoria própria.

\section{Exogone lourei Berkeley \& Berkeley, 1938}

Fig. 18

Exogone (Exogone) lourei SAN MARTÍN, 2005: 129-130, fig. 78; FUKUDA, 2010: 129131, fig. 36.

Material analisado: São Sebastião - Praia Grande, em Caulerpa lentilifera: 39 esp., 13.Dez.2015; Praia de São Francisco, em Sargassum sp.: 16 esp., 16.Jun.2016; Praia de São Francisco, em Gracilaria sp.: 27 esp., 16.Jun.2016; Praia de São Francisco, em Hypnea musciform: 120 esp., 16.Jun.2016; Praia Grande, em Caulerpa lentilifera: 1 esp., 30.Jun.2015. Todos os indivíduos foram coletados na zona entremarés. 
Descrição: animais de tamanho corpóreo mediano, com corpo subcilíndrico, com 0,9-5,625 mm de comprimento, apresentando 12-47 setígeros, e com largura de $0,1-0,275 \mathrm{~mm}$. Prostômio pequeno e ovalado, com 2 pares de olhos em trapézio, manchas ocelares ausentes. Palpos completamente fundidos, com formato triangular, levemente arredondados. Antena mediana com o triplo do comprimento das laterais, inserida na linha dos olhos anteriores, antenas laterais inseridas próximo à mediana, a cada lado dela. Peristômio ligeiramente menor do que os segmentos anteriores, cirros peristomiais ligeiramente menores do que os cirros dorsais. Antenas laterais, cirros peristomiais, dorsais ao longo do corpo e anais similares, papiliformes e pequenos; cirros ventrais digitiformes, consideravelmente menores do que os cirros dorsais, com menos da metade de seu comprimento. Parapódios com 2 acículas cada na região anterior, 1 acícula por parapódio a partir dos segmentos medianos (Fig. 18F). Cerdas falcígeras bidentadas e espinuladas, dente distal praticamente inconspícuo, cerdas pseudoespinígeras presentes, com processos triangulares na haste nos dois primeiros setígeros (Fig. 18A-B). Parapódios com 5-7 cerdas falcígeras e 1-2 pseudoespinígeras cada na região anterior, 3-5 falcígeras e 1 pseudoespinígera na mediana, e 2-4 falcígeras e 1 pseudoespinígera na posterior. Lâminas das pseudoespinígeras e falcígeras com variações dorso-ventral e ântero-posterior, medindo $47,5-12,5 \mu \mathrm{m}$ e $10-5 \mu \mathrm{m}$, respectivamente, na região anterior, 37,5-10 $\mu \mathrm{m}$ e 7,5-5 $\mu \mathrm{m}$ na mediana, e $22,5-10 \mu \mathrm{m}$ e 7,5-2,5 $\mu \mathrm{m}$ na posterior. Cerdas simples dorsais presentes em todos os parapódios, com leve espinulação subdistal, progressivamente mais robustas e menos espinuladas em direção posterior (Fig. 18C-D); cerdas simples ventrais bidentadas, presentes apenas na região posterior, com dente subdistal maior do que o distal (Fig. 18E). Pigídio com par de cirros anais alongados, com comprimento similar ao da antena mediana. Faringe ocupando cerca de 3-5 segmentos, com dente central grande, localizado na porção anterior, quase na margem. Proventrículo estendendo-se por 2,5-5 segmentos, com 16-24 feixes musculares. 
Discussão: a espécie possui registros para o litoral brasileiro e é bem conhecida e estudada nos três oceanos não polares. Os indíviduos encontrados neste estudo superam levemente, em comprimento, os previamente registrados em outros estudos feitos na mesma região, o maior indivíduo encontrado neste estudo possui 5,625 $\mathrm{mm}$ e o de outros estudos possuia 4,43 $\mathrm{mm}$ (FUKUDA, 2010). Esta foi a espécie mais abundante neste estudo.

Localidade-tipo: Colúmbia Britânica, Canadá (Oceano Pacífico).

Distribuição: Da costa canadense (Colúmbia Britânica) até o Panamá (Oceano Pacífico); Austrália (Oceano Índico); Ilhas Canárias, Caribe, Brasil (Oceano Atlântico).

Fig. 18 -Exogone (Exogone) lourei. A, cerdas pseudoespinígera e falcígera, região anterior, primeiro setígero; $\mathbf{B}$, cerdas pseudoespinígera e falcígera, região posterior; $\mathbf{C}$, cerda simples dorsal, região mediana; D, cerda simples dorsal, região posterior; $\mathbf{E}$, cerda simples ventral; $\mathbf{F}$, acículas da região anterior. Barra de escala: $\mathrm{A}-\mathrm{F}=10 \mu \mathrm{m}$.

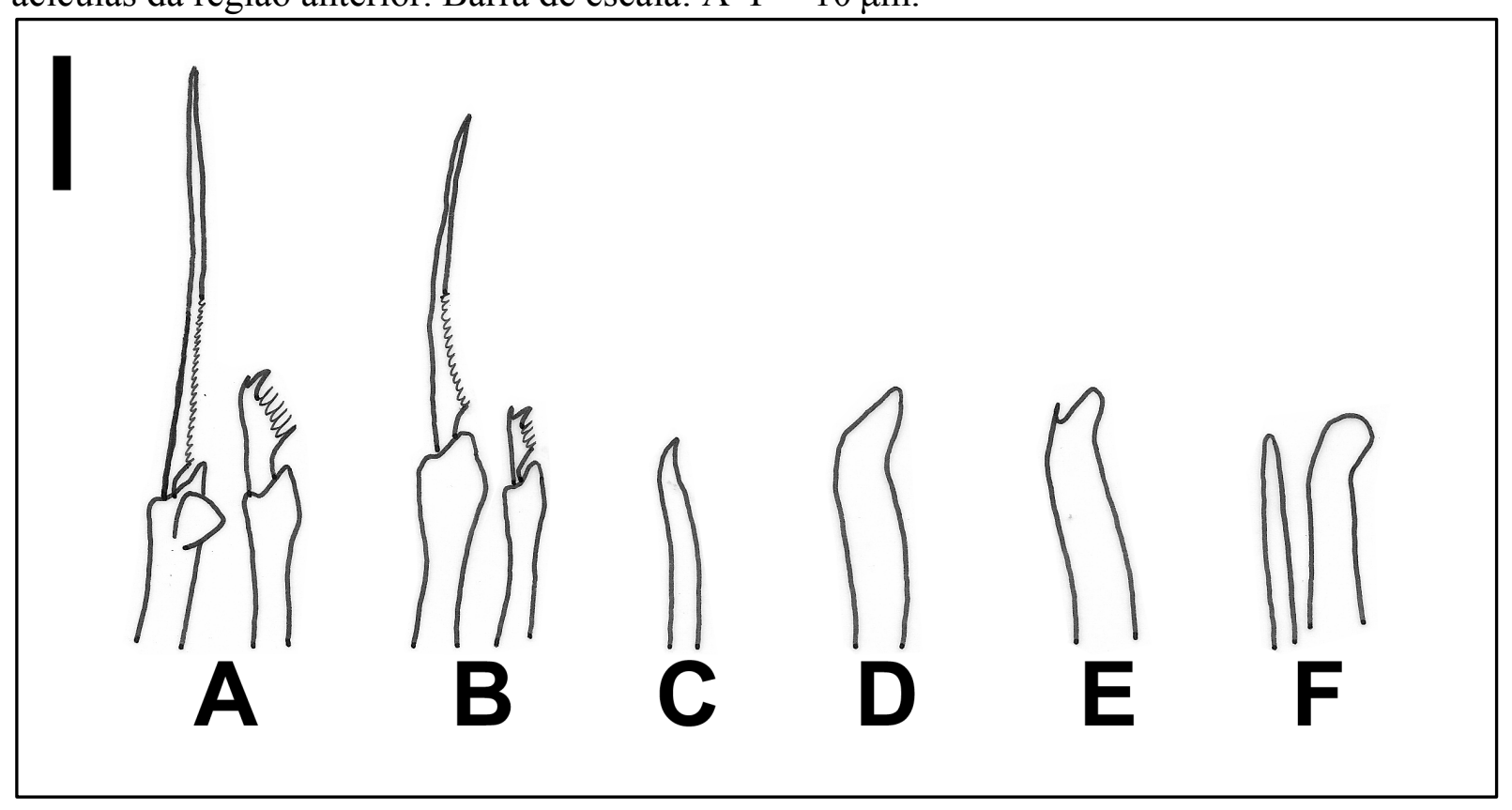

Fonte: Desenho de autoria própria.

\section{Gênero Sphaerosyllis Claparède, 1863}

Espécie-tipo: Sphaerosyllis hystrix Claparède, 1863. 
Diagnose: animais de pequeno porte, corpo subcilíndrico, com dorso frequentemente recoberto por papilas. Prostômio com 2 pares de olhos em trapézio, manchas ocelares ausentes, e 3 antenas. Palpos completamente fundidos, visíveis dorsalmente. Peristômio com 1 par de cirros peristômiais. Antenas, cirros peristomiais, dorsais ao longo do corpo e anais com mesma morfologia, subulados, em forma de garrafas ou pinos de boliche, com base bulbosa e ponta arredondada distalmente; cirros dorsais ausentes no setígero 2 . Parapódios com cerdas falcígeras, geralmente unidentadas e espinuladas. Acículas robustas, geralmente dobradas em $90^{\circ}$. Faringe com dente cônico na margem anterior, proventrículo curto, com poucas fileiras musculares. Incubação de ovos na superfície ventral do corpo.

Comentários: o gênero conta com 71 espécies registradas no mundo todo, destas, 13 das quais já foram registradas no litoral brasileiro (FUKUDA, 2010), incluindo a descrita neste estudo.

\section{Sphaerosyllis densopapillata Hartmann-Schröder, 1979}

Fig. 19

Sphaerosyllis densopapillata SAN MARTÍN, 2005: 92-94, figs. 48-49A-B; FUKUDA, 2010: 195-198, figs. 56-57.

Material analisado: São Sebastião - Praia Grande, em Caulerpa lentilifera: 3 esp., 13.Dez.2015; Praia Grande, em Hypnea musciform: 1 esp., 13.Dez.2015; Praia da Baleia, em Caulerpa lentilifera: 1 esp., 08.Abr.2015. Todos os indivíduos foram coletados na zona entremarés.

Descrição: animais de tamanho corpóreo pequeno, com corpo subcilíndrico, com 0,875-1,375 $\mathrm{mm}$ de comprimento, apresentando 12-22 setígeros, com 
largura de $0,15-0,2 \mathrm{~mm}$. Corpo recoberto por fileiras transversais de papilas grandes e arredondadas, tanto dorsal, quanto ventralmente, mais abundantes no dorso. Prostômio pequeno e ovalado, com 2 pares de olhos em trapézio. Palpos quase que totalmente fundidos, com formato triangular, levemente arredondados distalmente. Antena mediana com mesmo tamanho das laterais, todas inseridas na margem anterior do prostômio. Peristômio ligeiramente menor do que os segmentos anteriores, cirros peristomiais maiores do que os cirros dorsais. Antenas, cirros peristomiais, dorsais ao longo do corpo e anais similares, subulados; cirros ventrais digitiformes, de mesmo tamanho dos lóbulos parapodiais. Parapódios com 1 acícula cada em todos os segmentos, dobrada em ângulo reto subdistalmente (Fig. 19E). Cerdas falcígeras unidentadas e espinuladas, espinulação conspícua e bem demarcada na região anterior, lâminas fracamente espinuladas ou lisas na região posterior (Fig. 19A-B). Parapódios com 6-7 cerdas falcígeras cada na região anterior, 5-6 na mediana e 4-5 na posterior. Lâminas das falcígeras com variações dorso-ventral e ânteroposterior, medindo $45-15 \mu \mathrm{m}$ na região anterior, 37,5-12,5 $\mu \mathrm{m}$ na mediana $\mathrm{e}$ 32,5-10 $\mu \mathrm{m}$ na posterior. Cerdas simples dorsais unidentadas, presentes em todos os parapódios, com leve espinulação subdistal (Fig. 19C); cerdas simples ventrais unidentadas, presentes apenas na região posterior, lisas (Fig. 19D). Pigídio com par de cirros anais de mesmo tamanho das antenas. Faringe ocupando cerca de 2-3 segmentos, com dente central grande, localizado na porção anterior, quase na margem. Proventrículo estendendo-se por 2-3 segmentos, com 11-22 feixes musculares.

Discussão: membros de $S$. densopapillata se assemelham muito aos de $S$. magnidentata Perkins, 1981, em relação à morfologia das antenas e cirros dorsais, das cerdas e acículas nos parapódios, e da faringe e proventrículo. Contudo, elas se diferenciam pela característica mais marcante de exemplares de S. densopapillata, dorso e ventre totalmente recobertos por papilas arredondadas, enquanto membros de $S$. magnidentata não apresentam essas 
papilas tão concentradas na superfície corpórea, sendo essas mais distribuídas e em menor quantidade.

Localidade-tipo: Austrália, Broome (Oceano Índico).

Distribuição: Austrália (Oceano Pacífico); Austrália (Oceano Índico); Brasil (Oceano Atlântico).

Fig. 19- Sphaerosyllis densopapillata. A, cerdas falcígeras, região anterior; $\mathbf{B}$, cerdas falcígeras, região posterior; $\mathbf{C}$, cerda simples dorsal; $\mathbf{D}$, cerda simples ventral; $\mathbf{E}$, acícula da região anterior. Barra de escala: $\mathrm{A}-\mathrm{E}=10 \mu \mathrm{m}$.
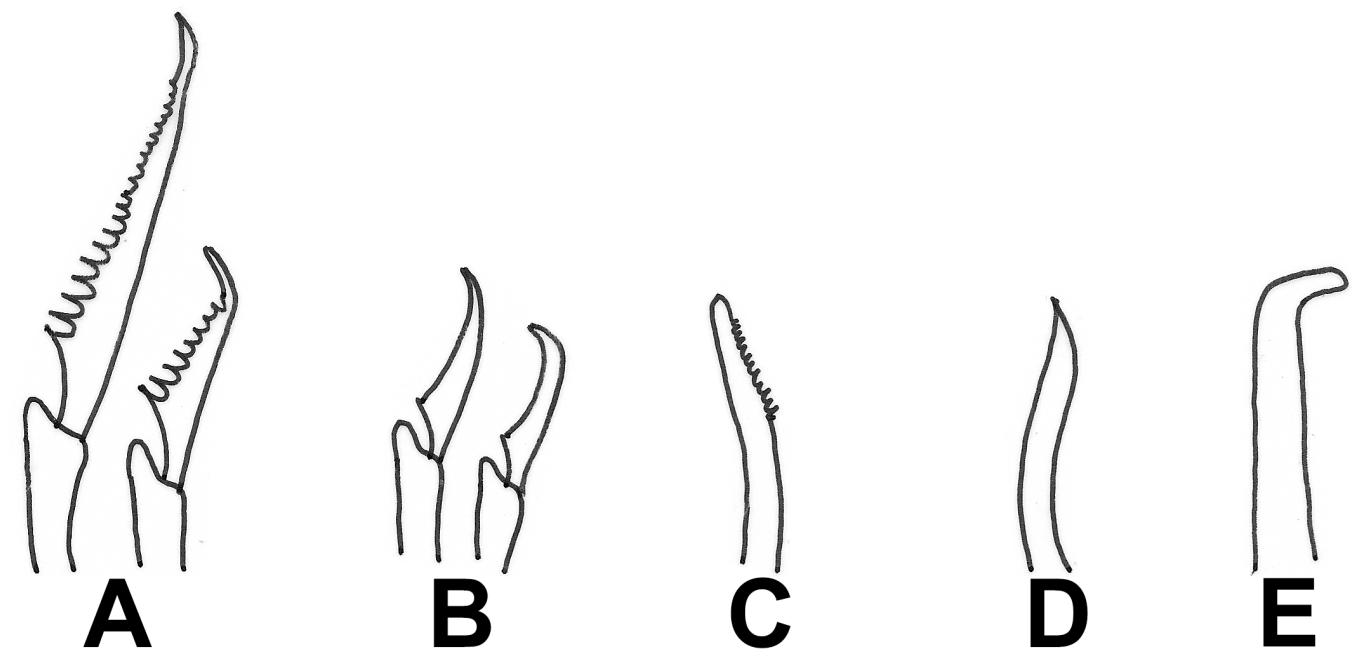

Fonte: Desenho de autoria própria.

\section{Subfamília Syllinae Rioja, 1925}

Diagnose: animais de tamanho corpóreo médio a grande, com corpo subcilíndrico ou dorso-ventralmente achatado. Prostômio com 2 pares de olhos, por vezes também com 1 par de manchas ocelares, e 3 antenas. Palpos livres, triangulares e arredondados. Peristômio com 2 pares de cirros peristomiais. Antenas, cirros peristomiais, dorsais e anais articulados, moniliformes, podendo ter apenas um artículo por cirro. Cerdas falcígeras, por vezes também com cerdas pseudoespinígeras; cerdas simples dorsais e ventrais comumente 
presentes na região posterior; alguns táxons podem apresentar cerdas secundariamente simples, por perda das lâminas, ou fusão destas com as hastes. Faringe com 1 dente central, podendo também apresentar um trépano.

Comentários: a subfamília em questão conta com 21 gêneros descritos. Destes, nove gêneros possuem ocorrência no litoral brasileiro, seis dos quais são contemplados neste estudo. É, sem dúvida, a subfamília mais abundante e mais bem conhecida de Syllidae, e aquela com maior representatividade neste estudo. Estes animais são facilmente identificados pelo padrão morfológico de seus apêndices (antenas, cirros peristomiais e dorsais ao longo do corpo), que são articulados, mesmo que só haja um artículo (no caso dos gêneros Eurysyllis Ehlers, 1864 e Plakosyllis Hartmann-Schöder, 1956).

\section{Chave de identificação para os gêneros de Syllinae encontrados neste estudo}

1a. Apenas cerdas secundariamente simples presentes.......................... Haplosyllis 1b. Cerdas falcígeras presentes, podendo também apresentar pseudoespinígeras.

2a. (1b) Corpo claramente mais fino na região mediana; segmentos apresentando subsegmentação Megasyllis

2b. Corpo de largura aproximadamente uniforme, afilado na região posterior; segmentos sem subsegmentação. 3

3a. (2b) Dente faríngeo grande, afastado da margem anterior, geralmente mais próximo ao proventrículo; trépano ausente Opisthosyllis

3b. Dente faríngeo, quando presente, próximo à margem anterior da faringe; trépano por vezes presente 
4a. (3b) Faringe com trépano, com coroa completa de dentes, podendo também apresentar dente central; corpo achatado dorso-ventralmente. Trypanosyllis

4b. Faringe sem trépano, com dente central; corpo subcilíndrico. 5

5a. (4b) Cerdas falcígeras modificadas, com lâminas curvadas em $90^{\circ} \mathrm{em}$ relação às hastes, em formato de gancho; cerdas pseudoespinígeras ausentes Branchiosyllis

5b. Cerdas em formato de gancho ausentes; pseudoespinígeras comumente presentes. Syllis

\section{Gênero Branchiosyllis Ehlers, 1887}

Espécie-tipo: Branchiosyllis oculata Ehlers, 1887.

Diagnose: animais de tamanho corpóreo médio a grande, corpo subcilíndrico e, geralmente, padrões de pigmentação espécie-específicos. Prostômio com 2 pares de olhos e 3 antenas. Palpos praticamente livres, fundidos apenas na porção basal. Peristômio com 2 pares de cirros peristomiais. Antenas, cirros peristomiais, cirros dorsais ao longo do corpo e anais com mesma morfologia, moniliformes. Parapódios com cerdas falcígeras, normalmente bidentadas e espinuladas, e, pelo menos nos setígeros posteriores falcígeras modificadas, com lâminas a $90^{\circ}$ em relação às hastes, assemelhando-se a um gancho; cerdas simples dorsais e ventrais frequentemente ausentes. Faringe com dente cônico central na margem anterior.

Comentários: o gênero é de fácil reconhecimento, devido à morfologia distinta das cerdas falcígeras posteriores. Das 25 espécies válidas do gênero, apenas 4 possuem registro para o litoral brasileiro, B. diazi Rioja, 1958, B. exilis (Gravier, 
1900), B. oculata Ehlers, 1887 e B. tamandarensis Paresque, Fukuda \& Nogueira, 2016.

\section{Branchiosyllis exilis (Gravier, 1900)}

Fig. 20

Branchiosyllis exilis NOGUEIRA, 2000: 98-99, fig. 22J-M; SAN MARTÍN et al., 2008a: 127-130, fig. 7, 8B-F; FUKUDA, 2010: 214-217, fig. 62.

Material analisado: São Sebastião - Praia Grande, em Caulerpa lentilifera: 1 esp., 13.Dez.2015; Praia de São Francisco, em Hypnea musciform: 8 esp., 16.Jun.2015; Praia de São Francisco, em Sargassum sp: 2 esp., 16.Jun.2015; Praia Grande, em Caulerpa lentilifera: 1 esp., 30.Jun.2015. Todos os indivíduos foram coletados na zona entremarés.

Descrição: animais de tamanho corpóreo médio a grande, com corpo subcilíndrico, com 3,25-10,55 $\mathrm{mm}$ de comprimento, apresentando 49-78 setígeros, e com largura de 0,25-0,75 mm. Pigmentação dorsal escura, com faixas transversais nos setígeros e grânulos escuros distribuídos pelos artículos dos cirros e antenas. Prostômio ovalado, com 2 pares de olhos em trapézio. Palpos livres, triangulares, arredondados distalmente. Antena mediana ligeiramente maior do que as laterais, com 10-24 artículos, inserida na linha dos olhos anteriores; antenas laterais inseridas na margem anterior do prostômio, com 15-20 artículos. Peristômio menor do que os segmentos anteriores, cirros peristomiais dorsais maiores do que as antenas, com 13-32 artículos, cirros peristomiais ventrais com aproximadamente o mesmo tamanho da antena mediana, com 10-24 artículos. Cirros dorsais da região anterior apresentando 18-46 artículos no primeiro setígero e 18-44 nos demais, cirros medianos com 17-44, cirros posteriores com 12-40 artículos. Antenas, cirros peristomiais e 
dorsais ao longo do corpo divididos em cirróforos e cirróstilos. Parapódios anteriores com 4-5 acículas cada, das quais uma é distalmente inclinada e as demais são retas e afiladas distalmente, 2-3 acículas por parapódio na região mediana, apenas 1 na região posterior (Fig. 20D). Cerdas falcígeras bidentadas e espinuladas, com dente distal maior; falcígeras com lâminas unidentadas e lisas por vezes presentes, no final da região mediana (Fig. 20A-B). Parapódios com 5-14 cerdas falcígeras cada, na região anterior, 6-7 falcígeras e 1-2 cerdas modificada na região mediana, e 4-6 cerdas modificadas na região posterior, falcígeras normais ausentes. Lâminas das falcígeras com variações dorso-ventral e ântero-posterior no comprimento, medindo 32,5-20 $\mu \mathrm{m}$ na região anterior e 22,5-17,5 $\mu \mathrm{m}$ na mediana. Cerdas modificadas em gancho presentes a partir da região mediana, mais grossas do que as demais, lisas, unidentadas, com lâminas dobradas em $90^{\circ}$ em relação às hastes; lâminas das cerdas modificadas medindo aproximadamente $32,5 \mu \mathrm{m}$ na região mediana e $50-37,5 \mu \mathrm{m}$ na posterior (Fig. 20C). Faringe ocupando cerca de 4-8 segmentos, com dente central grande, localizado na porção anterior, quase na margem. Proventrículo estendendo-se por 5-12 segmentos, com 24-48 feixes musculares.

Discussão: duas espécies do gênero se assemelham a $B$. exilis pelo padrão de pigmentação e pela ausência de brânquias parapodiais: $B$. cirropunctata (Michel, 1909) e B. maculata (Imajima, 1966). Entretanto, B. exilis apresenta as cerdas modificadas a partir da região mediana, enquanto em membros das outras duas espécies tais cerdas estão presentes apenas na região posterior. Além disso, membros de $B$. cirropunctata possuem as lâminas das falcígeras com morfologia distinta, mais finas, enquanto os de $B$. maculata possuem a pigmentação mais característica, tendo regiões do corpo com os cirros preenchidos por pequenos agrupamentos de pigmentação.

Localidade-tipo: Djibuti (Oceano Índico).

Distribuição: Espécie circumtropical, com registros no mar Egeu, Mediterrâneo e Vermelho; Ilhas Samoa (Oceano Pacífico); Mar do Caribe e litoral brasileiro 
(Oceano Alântico).

Fig. 20 - Branchiosyllis exilis. A, cerdas falcígeras, região anterior; B, cerdas falcígeras, região mediana; $\mathbf{C}$, cerdas modificadas; $\mathbf{D}$, acículas da região anterior. Barra de escala: A-E = $10 \mu \mathrm{m}$.

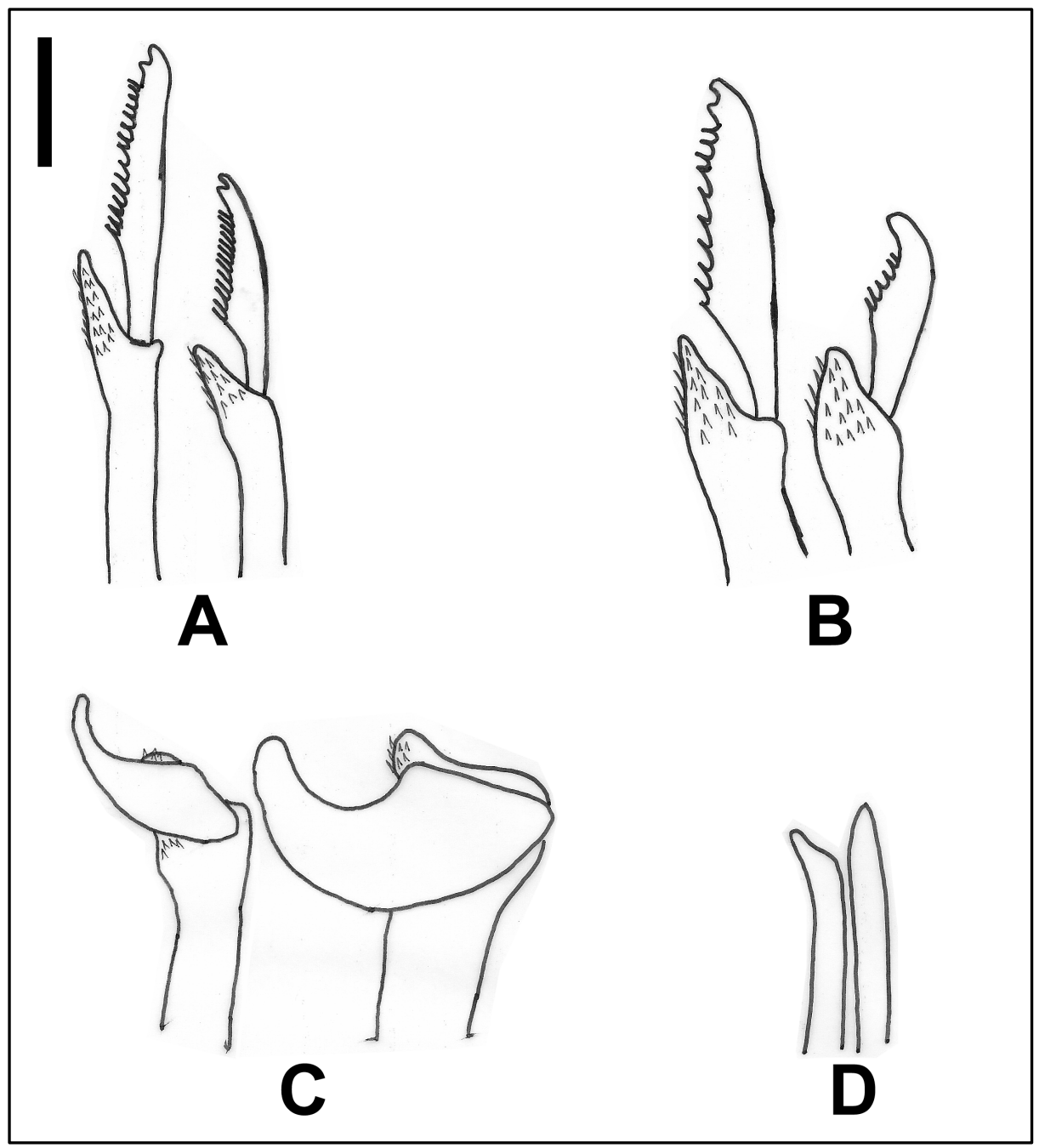

Fonte: Desenho de autoria própria.

Gênero Haplosyllis Langerhans, 1879

Espécie-tipo: Syllis spongicola Grube, 1855.

Diagnose: animais de tamanho corpóreo de médio a grande, com corpo subcilíndrico. Prostômio com 2 pares de olhos, podendo apresentar 1 par de manchas ocelares e 3 antenas. Palpos triangulares com a região anterior arredondada e a base fundida. Peristômio com 2 pares de cirros. Antenas, cirros 
peristomiais, dorsais e anais moniliformes. Faringe com dente central, podendo ou não apresentar trépano. Apenas cerdas simples presentes, originadas a partir da fusão entre hastes e lâminas.

Comentários: o gênero conta com 39 espécies válidas, 5 das quais já registradas no Brasil: H. amphimedonicola Paresque \& Nogueira, 2014, H. lattigae Paresque, Fukuda \& Nogueira, 2016, H. loboi Paola, San Martín \& Martin, 2006, H. rosenalessoae Paresque \& Nogueira, 2014 e H. spongicola (Grube, 1855). As duas espécies encontradas neste estudo foram descritas recentemente, a partir de exemplares do litoral nordestino brasileiro (PARESQUE \& NOGUEIRA, 2014).

\section{Chave de identificação para as espécies de Haplosyllis encontradas neste estudo}

- 2 acículas por parapódio na região mediana; tegumento não apresentando granulação interna conspícua. H. amphimedonicola

- 3 acículas por parapódio na região mediana; tegumento com granulação interna conspícua H. rosenalessoae

\section{Haplosyllis amphimedonicola Paresque \& Nogueira, 2014}

Fig. 21

Haplosyllis amphimedonicola PARESQUE \& NOGUEIRA, 2014: 558-570, fig. 1-4.

Material analisado: São Sebastião - Praia Grande, em Caulerpa lentilifera: 3 esp., 13.Dez.2015. Coletados na zona entremarés. 
Descrição: animais de tamanho corpóreo médio a grande, com corpo subcilíndrico, com 2,5-5,625 $\mathrm{mm}$ de comprimento, apresentando 19-29 setígeros, e com largura de 0,2-0,6 mm. Prostômio curto ovalado, com 2 pares de olhos em trapézio. Palpos triangulares alongados e levemente arredondados distalmente, fundidos na porção basal. Antena mediana ligeiramente maior do que as laterais, com 7-19 artículos, inserida na linha dos olhos anteriores; antenas laterais na margem anterior do prostômio, com 5-11 artículos. Peristômio menor do que os segmentos anteriores, cirros peristomiais dorsais menores do que a antena mediana, com 9-15 artículos, cirros peristomiais ventrais, praticamente do mesmo tamanho das antenas laterais, com 4-10 artículos. Antenas, cirros peristomiais, dorsais e anais moniliformes; cirros dorsais do primeiro setígero mais longos dos que os demais com 12-18 artículos, na região anterior cirros com 6-14 artículos, cirros medianos com 4-7 artículos e posteriores com 2-4 artículos; cirros da região anterior com alternância de comprimento pouco marcada. Parapódios com 2 acículas cada, nas regiões anterior e mediana, subdistalmente inclinadas, em alguns casos quase em ângulo reto (Fig. 21D), 1 acícula por parapódio na região posterior. Cerdas falcígeras bidentadas e secundariamente simples, com lâmina e haste fundidas, com dente subdistal maior do que o distal (Fig. 21A-C). Parapódios com 2 cerdas em todo o corpo. Faringe ocupando cerca de 3-5 segmentos, com dente central grande, localizado na porção anterior, quase na abertura. Proventrículo estendendo-se por 2,5-6 segmentos, com 20-36 feixes musculares.

Discussão: animais desta espécie se assemelham muito a membros de $H$. rosenalessoae Paresque \& Nogueira, 2014, contudo eles se diferenciam pelo tamanho do corpo, ausência de grânulos no interior do tegumento e número de acículas nos parapódios medianos. Os exemplares encontrados de $H$. amphimedonicola, em geral, são menores do que os de H. rosenalessoae e estes últimos possuem o tegumento repleto de inclusões granulares bastante 
conspícuas. Além disso, exemplares de H. amphimedonicola apresentam 2 acículas por parapódio nas regiões anterior e mediana, e 1 na posterior, enquanto membros de $H$. rosenalessoae têm 2 acículas por parapódio na região anterior, 3 na mediana e 1 na posterior.

Localidade-tipo: Barra de Mamanguape, Rio Tinto, Estado da Paraíba, Brasil $\left(06^{\circ} 45^{\prime} \mathrm{S}, 34^{\circ} 55^{\prime} \mathrm{O}\right)$.

Distribuição: Brasil (Paraíba a São Sebastião, São Paulo) (Oceano Atlântico).

Fig. 21 - Haplosyllis amphimedonicola. A, cerdas, região anterior; B, cerdas, região mediana; $\mathbf{C}$, cerda, região posterior; $\mathbf{D}$, acículas, região anterior. Barra de escala: $\mathrm{A}-\mathrm{D}=5 \mu \mathrm{m}$.
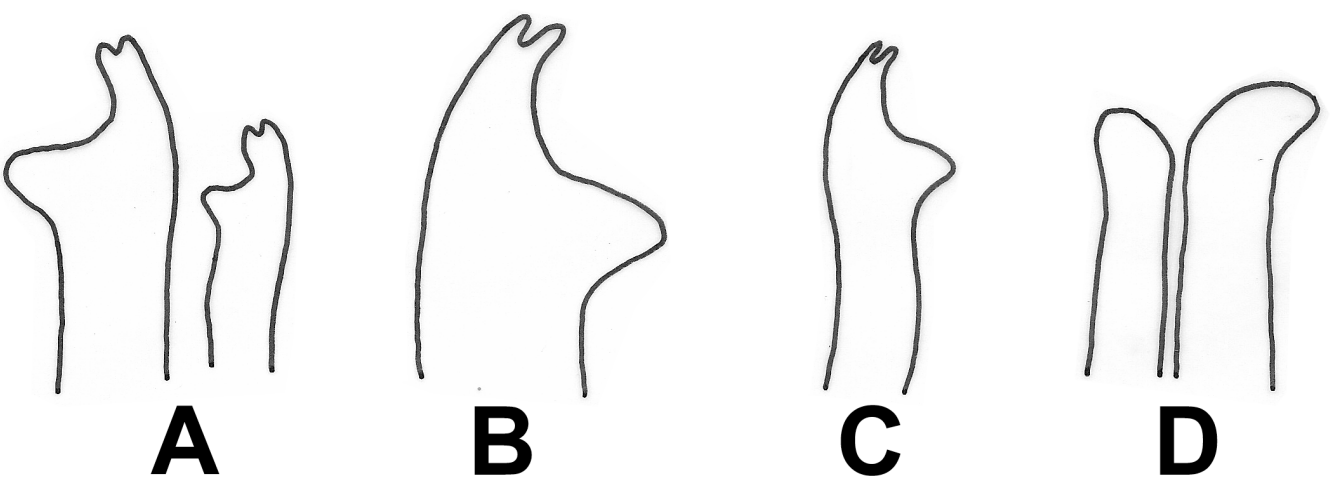

Fonte: Desenho de autoria própria.

\section{Haplosyllis rosenalessoae Paresque \& Nogueira, 2014}

Fig. 22

Haplosyllis rosenalessoae PARESQUE \& NOGUEIRA, 2014: 570-574, fig. 5-7.

Material analisado: São Sebastião - Praia Grande, em Caulerpa lentilifera: 23 esp., 13.Dez.2015; Praia da Baleia, em Caulerpa lentilifera: 2 esp., 08.Abr.2016; Praia de São Francisco, em Hypnea musciform: 2 esp., 16.Jun.2015. Todos os indivíduos foram coletados na zona entremarés.

Descrição: animais de tamanho corpóreo médio a grande, com corpo 
subcilíndrico e tegumento repleto de inclusões granulares internas, com 2,5-8 $\mathrm{mm}$ de comprimento, 20-54 setígeros e largura de 0,25-0,625 mm. Prostômio ovalado, com 2 pares de olhos em trapézio. Palpos triangulares alongados, levemente arredondados distalmente, fundidos na porção basal. Antena mediana maior do que as laterais, com 7-21 artículos, inserida na linha dos olhos posteriores; antenas laterais na margem anterior do prostômio, com 6-16 artículos. Peristômio menor do que os segmentos anteriores, cirros peristomiais dorsais do mesmo tamanho da antena mediana, com 7-22 artículos, cirros peristomiais ventrais com 4-18 artículos, aproximadamente do mesmo tamanho das lantenas laterais. Antenas, cirros peristomiais, dorsais ao longo do corpo e anais moniliformes; cirros dorsais do primeiro setígero mais longos do que a antena mediana, com 19-25 artículos, cirros dorsais seguintes com 7-21 artículos, os da região mediana com 5-9 artículos e os posteriores, com 2-6; cirros da região anterior com alternância no comprimento pouco marcada. Parapódios com 2 acículas cada, na região anterior, subdistalmente recurvadas, quase em ângulo reto e com a ponta arredondada (Fig. 22D), 3 acículas por parapódio na região mediana e 1 na posterior. Cerdas falcígeras bidentadas e secundariamente simples, lâmina e haste fundidas, com dente subdistal maior do que o distal (Fig. 22A-C); 2 cerdas por parapódio, ao longo de todo o corpo. Faringe ocupando de 3-8 segmentos, com dente central grande, localizado na porção anterior, quase na margem. Proventrículo estendendo-se por 2,5-9 segmentos, com 32-41 feixes musculares.

Discussão: membros da espécie descrita acima se assemelham muito aos de $H$. amphimedonicola, conforme discutido acima (Ver "Discussão" de $H$. amphimedonicola), mas se distinguem pelo tamanho do corpo, presença de inclusões granulares tegumentares, pelo número de acículas por parapódio, nos segmentos medianos e pelo nível de erosão apresentado pelo dente distal nas cerdas, nas regiões mediana e posterior.

Localidade-tipo: Praia de Cabo Branco, João Pessoa, Estado da Paraíba, Brasil 
( $\left.7^{\circ} 8.815^{\prime} \mathrm{S}, 34^{\circ} 47.773^{\prime} \mathrm{O}\right)$.

Distribuição: Da Paraíba a São Sebastião, São Paulo (Oceano Atlântico).

Fig. 22 - Haplosyllis rosenalessoae. A, cerdas, região anterior; B, cerdas, região mediana; C, cerdas, região posterior; $\mathbf{D}$, acículas, região anterior. Barra de escala: $\mathrm{A}-\mathrm{D}=5 \mu \mathrm{m}$.

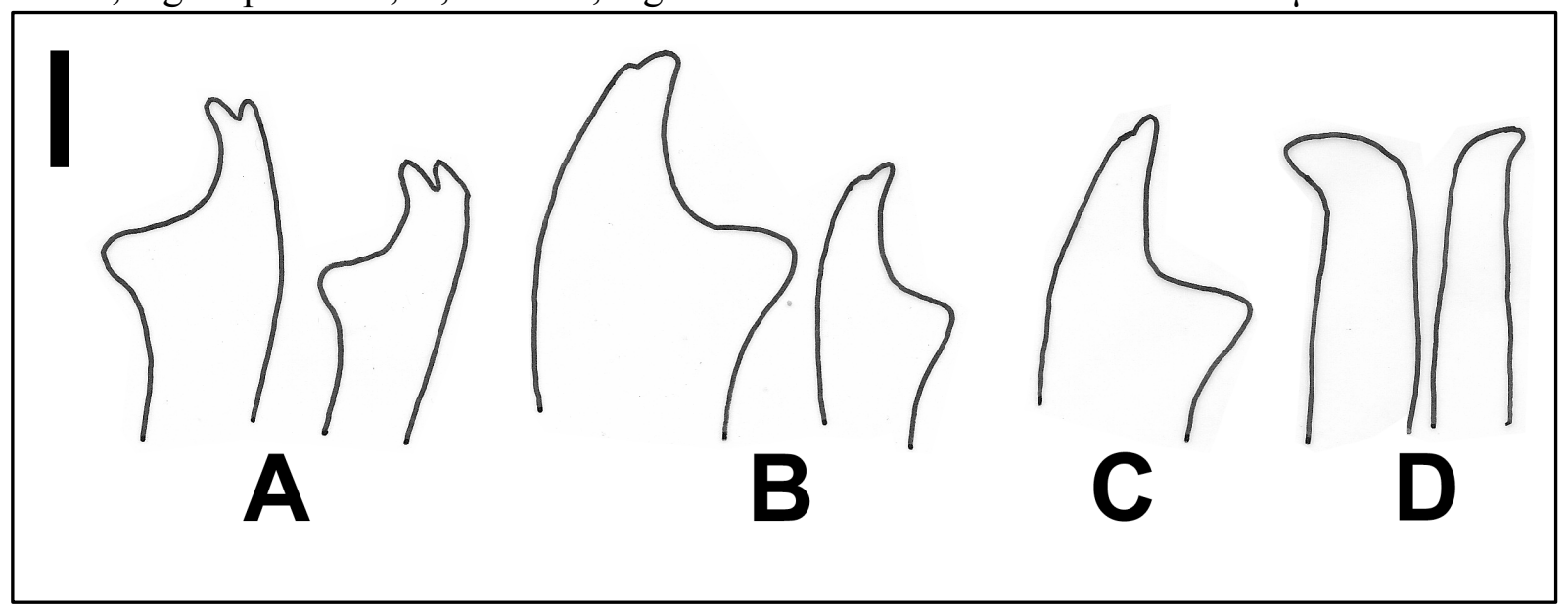

Fonte: Desenho de autoria própria.

\section{Gênero Megasyllis San Martín, Hutchings \& Aguado, 2008}

Espécie-tipo: Syllis corruscans Haswell, 1886.

Diagnose: animais de tamanho corpóreo de médio a grande, com corpo subcilíndrico, apresentando variação na largura, sendo a região mediana mais fina do que as demais. Membros de algumas espécies com padrões característicos de pigmentação. Prostômio com 2 pares de olhos e 3 antenas. Palpos arredondados, largos e com a base fundida. Peristômio com 2 pares de cirros. Segmentos do corpo geralmente subanelados, com 2-3 subanelações. Antenas, cirros peristomiais, dorsais ao longo do corpo e anais moniliformes, frequentemente divididos em cirróforo e cirróstilo. Cerdas falcígeras bidentadas, geralmente com dentes de mesmo tamanho, ou o subdistal ligeiramente maior. Faringe com tamanho similar ao proventriculo ou levemente menor, com dente 
cônico central, próximo à margem anterior. Cerdas simples dorsal e ventral presentes na região posterior.

Comentários: o gênero conta com 14 espécies conhecidas, das quais apenas $M$. procera possui registros em litoral brasileiro (NOGUEIRA, 2000; FUKUDA, 2010), em ambos os casos como Pionosyllis procera.

\section{Chave de identificação para as espécies de Megasyllis encontradas neste estudo}

- Corpo verde, com manchas acastanhadas na região posterior M. procera

- Corpo amarelado, com manchas castanho-avermelhadas bastante conspícuas na região anterior, em dois semicírculos posteriores ao prostômio M. sp. 1 sp. nov.

\section{Megasyllis procera (Hartman, 1965)}

Fig. 23

Pionosyllis procera NOGUEIRA, 2000: 81-82, Fig. 20A-F; FUKUDA, 2010: 81-84, Fig. 22.

Megasyllis procera PARESQUE, 2014: 165-168, fig. 15-21; SAN MARTíN et al. 2014: $347-348$.

Material analisado: São Sebastião - Praia Grande, em Hypnea musciform: 3 esp., 13.Dez.2015; Praia da Baleia, em Caulerpa lentilifera: 2 esp., 08.Abr.2015; Praia da Baleia, em Dyctiota ciliolata: 47 esp., 08.Abr.2015; Praia de São Francisco, em Hypnea musciform: 1 esp., 16.Jun.2015. Todos os indivíduos foram coletados na zona entremarés.

Descrição: animais de tamanho corpóreo médio a grande, com corpo 
subcilíndrico com pigmentação verde e algumas manchas marrons na região posterior, com 1,375-18,875 $\mathrm{mm}$ de comprimento e 16-92 setígeros. Corpo caracteristicamente mais fino na região mediana, com largura entre 0,1-0,375 $\mathrm{mm}$, mais robusto nas regiões anterior e posterior, 0,175-0,625 mm. Prostômio ovalado, com 2 pares de olhos em trapézio. Palpos arredondados e alongados, fundidos na porção basal. Antena mediana maior do que as laterais, com 14-19 artículos, inserida na linha dos olhos posteriores; antenas laterais na margem anterior do prostômio, com 9-16 artículos. Peristômio menor do que os segmentos anteriores, cirros peristomiais dorsais do mesmo tamanho da antena mediana, com 15-20 artículos, cirros peristomiais ventrais com 10-17 artículos, aproximadamente do mesmo tamanho das antenas laterais. Antenas, cirros peristomiais, dorsais ao longo do corpo e anais moniliformes; cirros dorsais do primeiro setígero ligeiramente maiores com 15-18 artículos, cirros dorsais seguintes com 16-9 artículos, os da região mediana com 8-14 artículos e os posteriores, com 9-1; cirros dorsais da região anterior com alternância de comprimento. Parapódios com 3-4 acículas cada, na região anterior, algumas retas e afiladas distalmente, outras subdistalmente inclinadas (Fig. 23E), 2-3 acículas por parapódio na mediana e 1-2 na posterior. Parapódios com 8-14 cerdas falcígeras, na região anterior, 6-10 na mediana, e 5-10 na posterior; cerdas simples dorsais finas e pontiagudas, cerdas simples ventrais finas e bidentadas, ambas presentes apenas na região posterior (Fig. 23C-D). Cerdas falcígeras bidentadas, com dente subdistal maior do que o distal (Fig. 23A-B); lâminas das cerdas da região anterior medindo $35-7,5 \mu \mathrm{m}, 20-5 \mu \mathrm{m}$ na região mediana, e 17,5-5 $\mu \mathrm{m}$ na posterior. Faringe ocupando 3-5 segmentos, com dente central grande, localizado na porção anterior, quase na margem. Proventrículo estendendo-se por 2-6 segmentos, com 24-32 feixes musculares.

Discussão: esta espécie é a única do gênero já conhecida para no litoral brasileiro (PARESQUE, 2014), facilmente identificável pela coloração de seus exemplares, sendo esta característica determinante para a diferenciação de 
membros desta da espécie dos pertencentes a M. tigrina San Martín, Aguado \& Álvarez-Campos, 2014, que possuem duas faixas transversais avermelhadas por setígero, bem como uma mancha ovalada na base de cada cirro dorsal, de mesma cor. Exemplares de M. mariandreworum San Martín, Aguado \& Álvarez-Campos, 2014 também se assemelham bastante aos de M. procera, mas se distinguem deles na morfologia das acículas e cerdas, sendo que em $M$. procera ambas as estruturas são mais finas, e em $M$. mariandreworum as acículas são mais oblíquas do que as de $M$. procera.

Localidade-tipo: Costa norte americana do Oceano Atlântico.

Distribuição: EUA, Cabo Verde, sul e sudoeste da África, Cuba; Brasil (Paraíba a São Paulo) (Oceano Atlântico).

Fig. 23 - Megasyllis procera. A, cerdas falcígeras, região anterior; $\mathbf{B}$, cerdas falcígeras, região posterior; $\mathbf{C}$, cerdas simples dorsais; $\mathbf{D}$, cerda simples ventral; $\mathbf{E}$, acículas, região anterior.

Barra de escala: A-E $=20 \mu \mathrm{m}$.
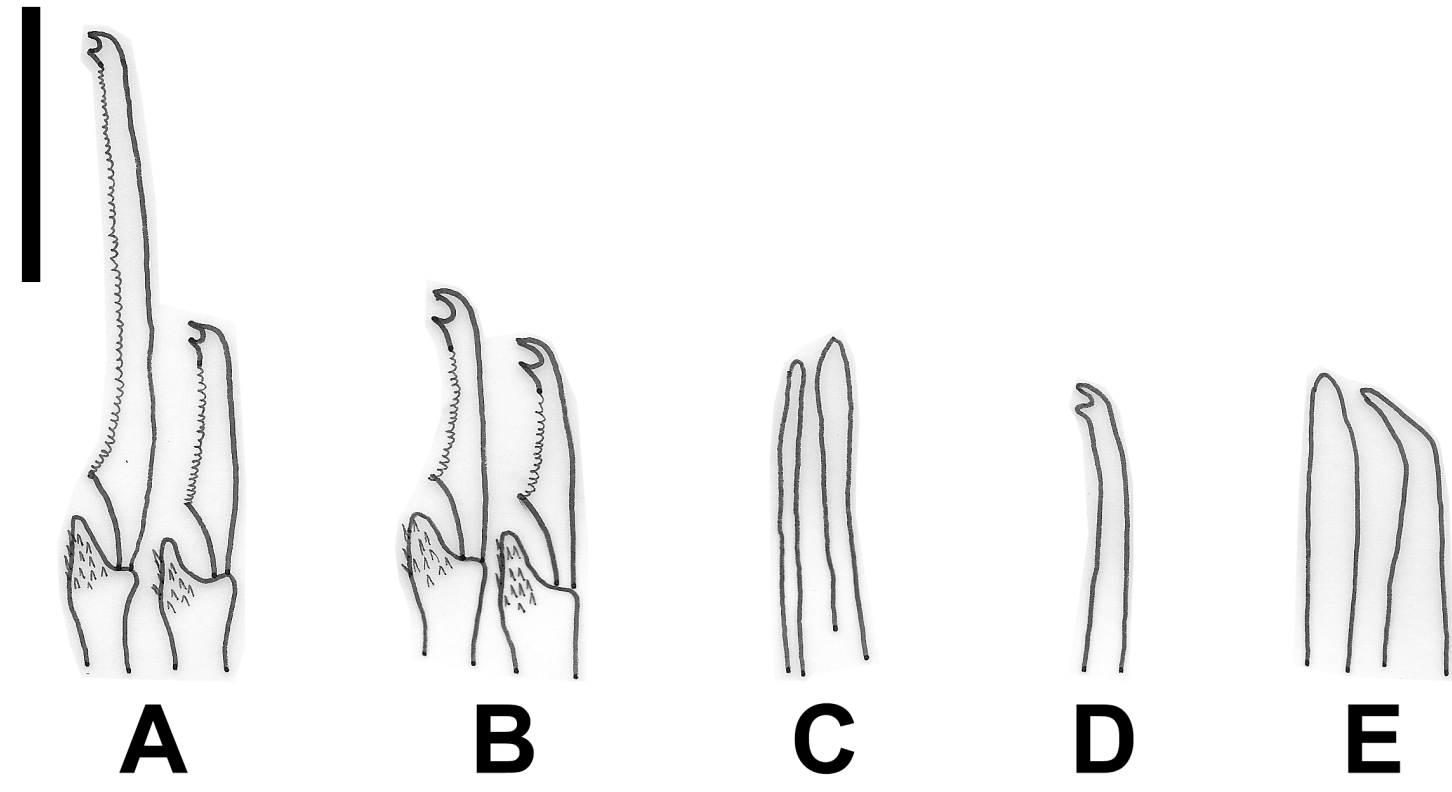

Fonte: Desenho de autoria própria.

\section{Megasyllis sp. 1 sp. nov.}

Fig. 24, 25

Material analisado: São Sebastião - Praia Grande, em Caulerpa lentilifera: 2 
esp., 30.Jun.2015. Coletados na zona entremarés.

Descrição: animais de tamanho corpóreo médio a grande, com corpo subcilíndrico amarelado, com pigmentação castanho-avermelhada característica, na forma de 2 manchas semicirculares posteriores ao prostômio, estendendo-se até a margem posterior do setígero 1 (Fig. 23), bem como nas antenas, cirros peristomiais e cirros dorsais dos setígeros anteriores, esmaecendo em direção posterior. Corpo com 3,75-6,375 mm de comprimento, com 42-77 setígeros, mais fino na região mediana, com $0,175-0,25 \mathrm{~mm}$ de largura, mais robusto nas regiões anterior e posterior, com 0,425-0,5 mm. Prostômio ovalado, com 2 pares de olhos em trapézio e 1 par de manchas ocelares. Palpos arredondados e alongados, fundidos na porção basal. Antena mediana maior do que as laterais, com 11-12 artículos, inserida na linha dos olhos posteriores; antenas laterais na margem anterior do prostômio, com $\sim 8$ artículos. Peristômio menor do que os segmentos anteriores, cirros peristomiais dorsais pouco menores do que a antena mediana, com 9-10 artículos, cirros peristomiais ventrais com 7-8 artículos, aproximadamente de mesmo tamanho das antenas laterais. Antenas, cirros peristomiais, dorsais ao longo do corpo e anais moniliformes (Figs. 24A, 25); cirros dorsais do primeiro setígero mais compridos do que a antena mediana, com 14-17 artículos, cirros dorsais seguintes com 12-14 artículos, os da região mediana com 8-5 artículos e os posteriores, com $\sim 7$ artículos; cirros dorsais da região anterior com alternância no comprimento. Parapódios com 3 acículas cada, na região anterior, retas e pontiagudas, com a ponta arredondada e subdistalmente recurvadas em um ângulo quase reto, 2-3 acículas por parapódio na região mediana e 1 acícula na posterior (Fig. 24D). Cerdas falcígeras com lâminas bidentadas, com dente subdistal maior do que o distal, as da região anterior medindo $30-20 \mu \mathrm{m}, 22,5-10 \mu \mathrm{m}$ na região mediana e $12,5-7,5 \mu \mathrm{m}$ na posterior (Fig. 24B-C). Parapódios com 10-12 cerdas falcígeras na região anterior, 7-9 na mediana e 6-7 na posterior; cerdas simples dorsais finas e 
pontiagudas, cerdas simples ventrais finas e bidentadas, ambas presentes apenas na região posterior. Faringe ocupando 5-6 segmentos, com dente central grande, localizado na porção anterior, quase na margem. Proventrículo estendendo-se por 4-5 segmentos, com 23-26 feixes musculares.

Discussão: animais pertencentes a esta espécie, se assemelham a exemplares de M. prolifera, mas diferem na coloração e no número de cerdas e acículas por parapódio ao longo do corpo, bem como o tamanho das lâminas das falcígeras, sendo estas menores na espécie nova. A variação na largura e o tamanho corpóreo acaba sendo maior em comparação com membros de M. prolifera.

Fig. 24 - Megasyllis sp. 1. A, região anterior, vista dorsal; B, cerdas falcígeras, região anterior; $\mathbf{C}$, cerdas falcígeras, região posterior; D, acículas, região anterior. Barra de escala: A $=0,2 \mathrm{~mm} ; \mathrm{B}-\mathrm{D}=20 \mu \mathrm{m}$.

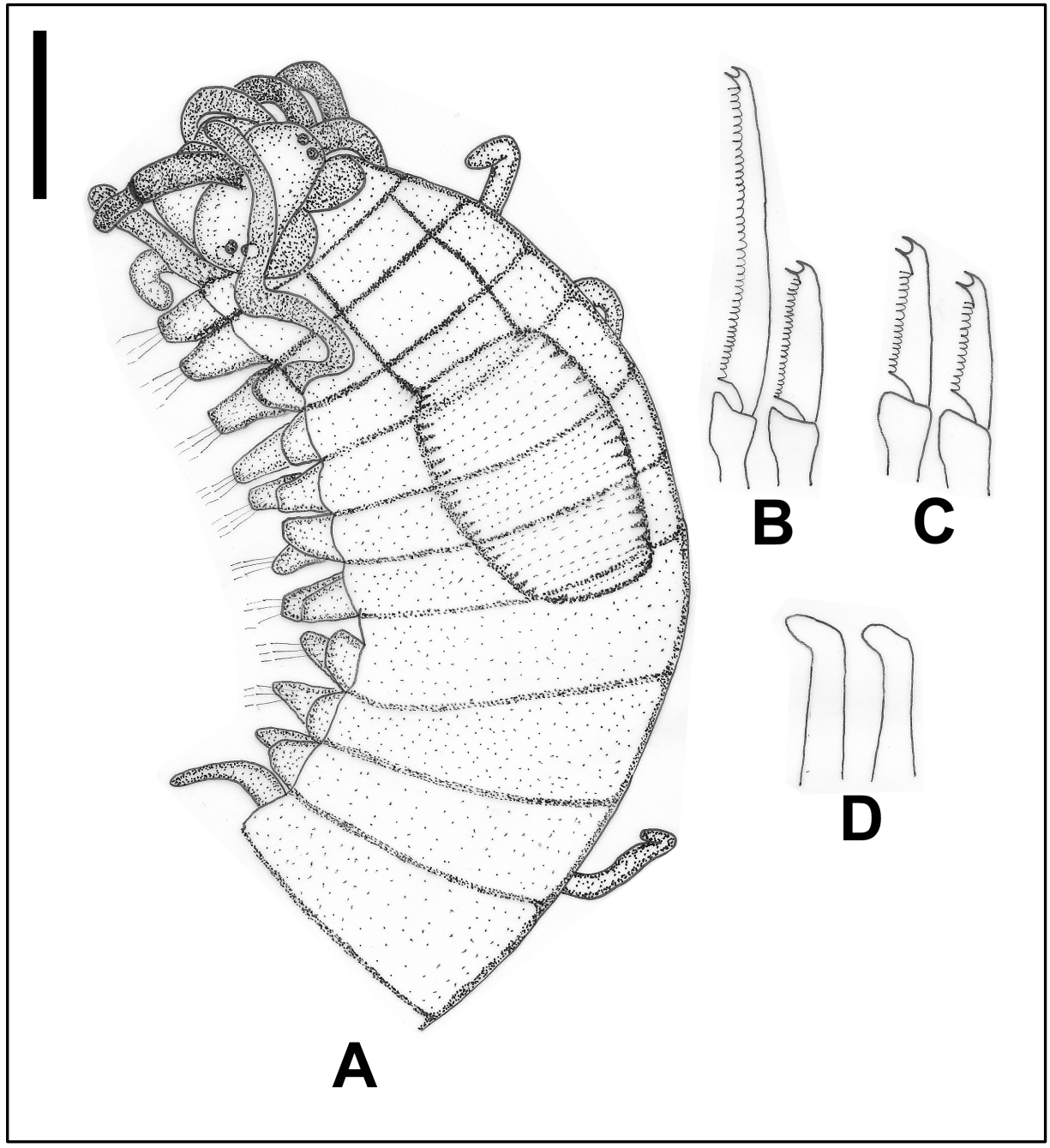

Fonte: Desenho de autoria própria. 
Fig. 25 - Megasyllis sp.1.Região anterior, vista dorsal; destaque para padrão de pigmentação dorsal. Barra de escala: $0,15 \mathrm{~mm}$.

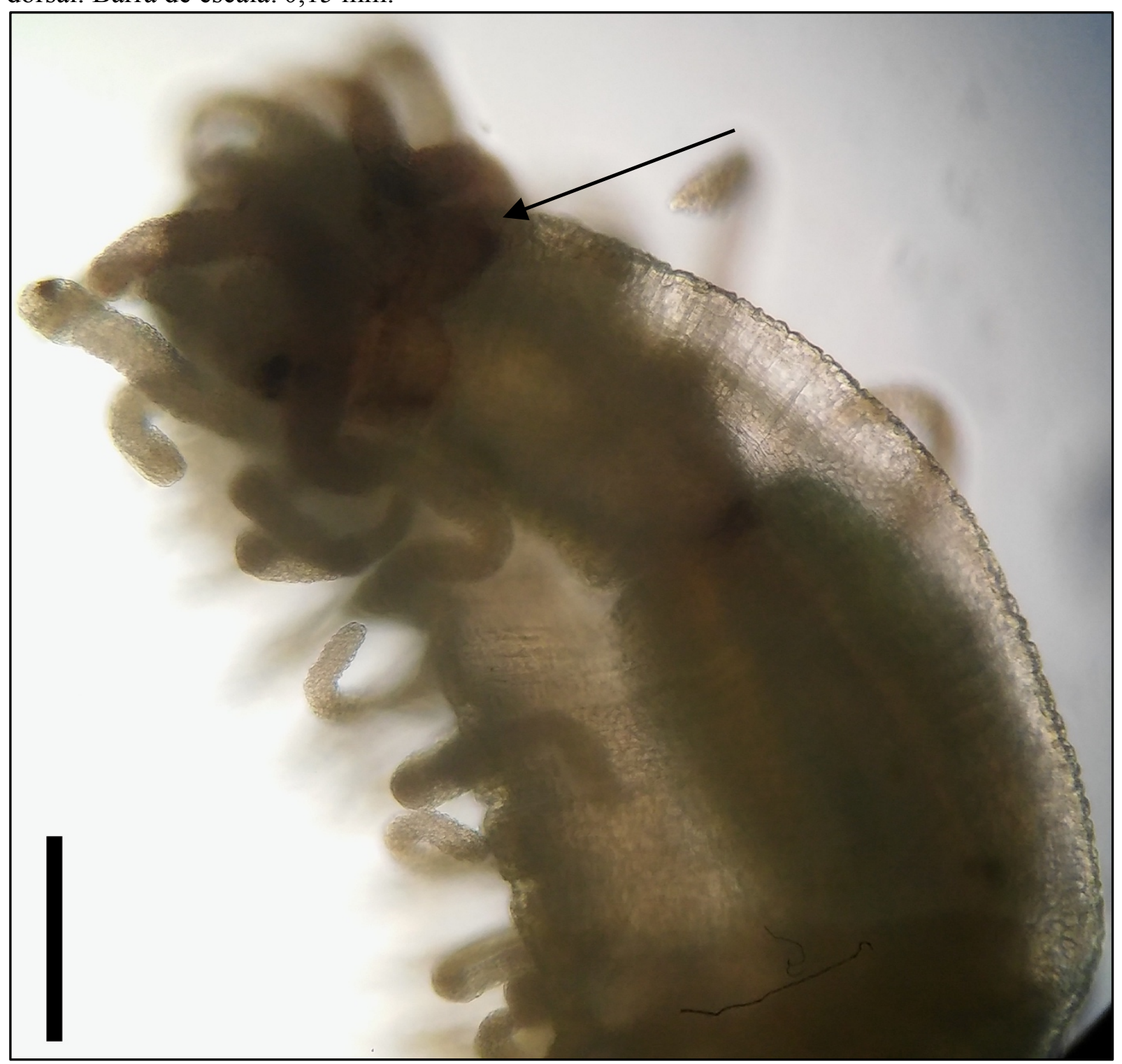

Fonte: Fotografia de autoria própria.

\section{Gênero Opisthosyllis Langerhans, 1879}

Espécie-tipo: Opisthosyllis brunnea Langerhans, 1879.

Diagnose: animais de tamanho corpóreo de médio a grande, com corpo subcilíndrico. Prostômio ovalado com 2 pares de olhos e 3 antenas. Palpos arredondados e alongados, fundidos na porção basal. Peristômio com 2 pares de cirros, frequentemente com um lóbulo nucal recobrindo parte do prostômio. 
Antenas, cirros peristomiais, dorsais ao longo do corpo e anais moniliformes, frequentemente divididos em cirróforo e cirróstilo. Cerdas falcígeras unidentadas. Faringe com um dente cônico central, situado após a porção mediana da faringe, mais próximo do proventrículo do que da margem anterior.

Comentários: o gênero possui 16 espécies válidas, das quais 3 já foram registradas no litoral brasileiro: O. brunnea Langerhans, 1879, O. corallicola Hartmann-Schöder, 1965, e O. viridis Langerhans, 1879. Exemplares destas espécies são diferenciados pela presença de lóbulo nucal, presença de papilas recobrindo a superfície dorsal dos animais e pelo formato das lâminas das cerdas falcígeras.

\section{Opisthosyllis brunnea Langerhans, 1879}

Fig. 26

Opisthosyllis brunnea NOGUEIRA, 2006: 164; SAN MARTÍN et al., 2008b: 23-26, figs. 16, 17A-B; FUKUDA, 2010: 227-231, fig. 66.

Material analisado: São Sebastião - Praia Grande, em Caulerpa lentilifera: 1 esp., 13.Dez.2015; Praia da Baleia, em Caulerpa lentilifera: 2 esp., 08.Abr.2015; Praia da Baleia, em Dyctiota ciliolata: 3 esp., 08.Abr.2015; Praia Grande, em Caulerpa lentilifera: 1 esp., 30.Jun.2015. Todos os indivíduos foram coletados na zona entremarés.

Descrição: animais de tamanho corpóreo médio a grande, com corpo subcilíndrico com coloração castanho-avermelhada característica, podendo apresentar linhas transversais escuras na região anterior. Corpo com 2,375$12,75 \mathrm{~mm}$ de comprimento, 31-92 setígeros e 0,25-0,75 $\mathrm{mm}$ de largura. Prostômio ovalado, com 2 pares de olhos em trapézio. Palpos afilados e bastante 
alongados, fundidos na porção basal. Antena mediana maior do que as laterais, com 15-22 artículos, inserida na linha dos olhos posteriores; antenas laterais na margem anterior do prostômio, com 8-20 artículos. Peristômio menor do que os segmentos anteriores, cirros peristomiais dorsais aproximadamente de mesmo tamanho da antena mediana, com 15-22 artículos, cirros peristomiais ventrais com 10-16 artículos, aproximadamente do mesmo tamanho das antenas laterais; lóbulo nucal semicircular, alcançando a base da antena central. Antenas, cirros peristomiais, dorsais ao longo do corpo e anais moniliformes; cirros dorsais do primeiro setígero com aproximadamente o dobro do comprimento da antena mediana, com 42-45 artículos, cirros dorsais seguintes com 18-42 artículos, os da região mediana com 11-35 e os posteriores, com 5-25 artículos; cirros dorsais ao longo do corpo com alternância no comprimento. Parapódios com 43 acículas cada, na região anterior, distalmente infladas e aparentemente ocas (Fig. 26F), 2 acículas por parapódio na região mediana e 1 na posterior. Cerdas falcígeras com lâminas unidentadas ou sub-bidentadas, com dente subdistal, se presente, assemelhando-se a uma espinha (Fig. 26A-C), as da região anterior medindo 37,5-15 $\mu \mathrm{m}, 27,5-12,5 \mu \mathrm{m}$ na mediana e $20-10 \mu \mathrm{m}$ na posterior. Parapódios com 10-15 cerdas falcígeras cada, na região anterior, 6-12 na mediana e 4-9 na posterior; cerdas simples dorsais espinuladas e distalmente arredondadas, cerdas simples ventrais pontiagudas e levemente recurvadas, sigmóides, presentes apenas na região posterior (Fig. 26D-E). Faringe ocupando 5-12 segmentos, com dente central grande, oval, localizado na porção posterior, mais próximo do proventrículo do que da margem anterior. Proventrículo estendendo-se por 4-10 segmentos, com 52-65 feixes musculares.

Discussão: os espécimes analisados nesse estudo correspondem à descrição feita para outros espécimes encontrados na região (FUKUDA, 2010).

Localidade-tipo: Portugal, Ilha da Madeira (Oceano Atlântico).

Distribuição: Austrália (Oceano Pacífico); Austrália, Moçambique, África do Sul (Oceano Índico); Mar Mediterrâneo, Espanha (Ilhas Baleares e Ilhas 
Chafarinas), Portugal (Ilha da Madeira) e Brasil (São Paulo) (Oceano Atlântico).

Fig. 26 - Opisthosyllis brunnea. A, cerdas falcígeras, região anterior; $\mathbf{B}$, cerdas falcígeras, região mediana; $\mathbf{C}$, cerdas falcígeras, região posterior; $\mathbf{D}$, cerda simples dorsal; $\mathbf{E}$, cerda simples ventral; $\mathbf{F}$, acículas, região anterior. Barra de escala: $\mathrm{A}-\mathrm{E}=40 \mu \mathrm{m}$.

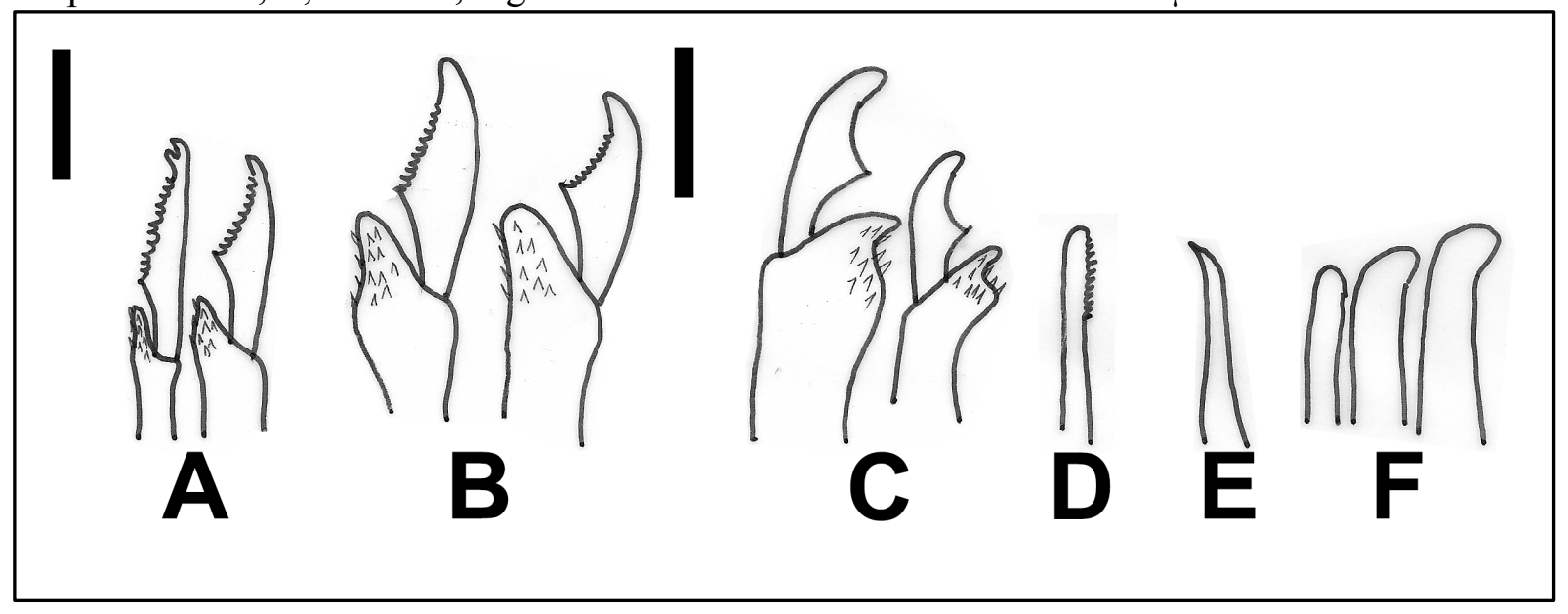

Fonte: Desenho de autoria própria.

\section{Gênero Syllis Lamarck, 1818}

Espécie-tipo: Syllis monilaris Lamarck, 1818.

Diagnose: animais de tamanho corpóreo variável, com corpo subcilíndrico, frequentemente com grande número de setígeros. Algumas espécies podem apresentar padrões característicos de pigmentação. Prostômio com 2 pares de olhos, frequentemente 1 par de manchas ocelares e 3 antenas. Palpos arredondados, largos e robustos, livres ou parcialmente fundidos na porção basal. Peristômio com 2 pares de cirros. Antenas, cirros peristomiais, dorsais ao longo do corpo e anais moniliformes, os dos setígeros anteriores, principalmente os do setígero 1, muito maiores do que os demais; parapódios frequentemente alternando cirros longos e curtos, exceto pelos mais anteriores. Cerdas falcígeras com lâminas de comprimento variável, cerdas pseudoespinígeras frequentemente presentes. Cerdas simples dorsais e ventrais geralmente 
presentes, pelo menos nos setígeros posteriores. Faringe com dente cônico central, trépano ausente.

Comentários: este gênero é um dos mais conhecidos da família, com 131 espécies válidas, das quais 29 já foram registradas no litoral brasileiro (AMARAL et al., 2013), incluindo 8 das 9 espécies encontradas no presente estudo.

\section{Chave de identificação para as espécies de Syllis neste estudo}

1a. Acículas com a região subdistal levemente inflada, com ponta oblíqua.........2

1b. Acícula com morfologia distinta.

2a. (1a) Cerdas pseudoespinígeras presentes

S. hyllebergi

2b. Cerdas pseudoespinígeras ausentes 3

3a. (2b) Falcígeras bidentadas, com dente subdistal maior, a partir da região mediana; espinulação conspícua, com espinhas distais mais longas, voltadas para cima, alcançando o dente subdistal S. lutea

3b. Falcígeras bidentadas, com dente subdistal menor ou de mesmo tamanho do distal; espinulação presente, com espinhas distais mais longas, mas não alcançando o dente subdistal

4a. (3b) Cirros dorsais curtos, com menos de 15 artículos cada; pigmentação escura, se presente, como faixas transversais, na região mediana dos setígeros...5 4b. (3b) Cirros dorsais longos, com mais de 15 artículos por segmento; Pigmentação distinta acastanhada, com desenho similar ao número " 8 " de lado, no dorso de cada setígero. 
5a. (4a) Padrão de pigmentação presente no corpo inteiro; falcígeras com espinhas ligeiramente voltadas para cima, robustas e curtas...S. pseudoarmillaris 5b. (4a) Padrão de pigmentação presente apenas na região anterior, em raros casos, na região mediana; falcígeras com espinhas retas, robustas e alongadas. S. sp. 1 sp. nov.

6a. (4b) Lâminas das falcígeras com dentes de tamanho similar, grandes; cirros dorsais sem inclusões. S. corallicola 6b. Lâminas das falcígeras com distal maior e mais robusto; cirros dorsais com inclusões granulares S. westheidei

7a. (1b) Acículas posteriores distalmente arredondadas e recurvadas, em forma de colher.

S. prolifera

7b. (1b) Acículas da região posterior dobradas em ângulo reto, ou praticamente. .8

8a. (7b) Cerdas pseudoespinígeras presentes S. rosea 8b. (7b) Cerdas pseudoespinígeras ausentes S. truncata

\section{Syllis corallicola Verrill, 1900}

Fig. 27

Syllis corallicola NOGUEIRA, 2000: 116, fig. 28; NOGUEIRA \& SAN MARTÍN, 2002: 7375, figs. 11-12; FUKUDA, 2010: 250-253.

Material analisado: São Sebastião - Praia da Baleia, em Dyctiota ciliolata: 1 esp., 08.Abr.2015; Praia de São Francisco, em Sargassum sp.: 1 esp., 16.Jun.2015; Praia de São Francisco, em Gracilaria sp.: 1 esp., 16.Jun.2015. Todos os indivíduos foram coletados na zona entremarés. 
Descrição: animais de tamanho corpóreo médio, com corpo subcilíndrico com pigmentação escura no dorso, castanha a avermelhada, em linhas transversais que delimitam uma área despigmentada em forma de " 8 " transversal, padrão conhecido como "pigmentação tipo-variegata". Corpo com3-5,625 mm de comprimento,35-64 setígeros e 0,25-0,625 mm de largura. Prostômio ovalado, com 2 pares de olhos em trapézio e, geralmente, 1 par de manchas ocelares. Palpos triangulares alongados, distalmente arredondados, fundidos na porção basal. Antena mediana maior do que as laterais, com 17-23 artículos, inserida no centro do prostômio, entre o par de olhos anteriores; antenas laterais à frente da antena central, próximo às manchas ocelares, com 12-15 artículos. Peristômio menor do que os segmentos anteriores, cirros peristomiais dorsais pouco menores do que a antena mediana, com 12-18 artículos, cirros peristomiais ventrais com 12-14 artículos, aproximadamente do mesmo tamanho das antenas laterais. Antenas, cirros peristomiais, dorsais ao longo do corpo e anais moniliformes; cirros dorsais do primeiro setígero mais longos do que a antena mediana, com 32-35 artículos, cirros dorsais seguintes com 25-30 artículos, os da região mediana com 16-25 artículos e os posteriores, com 8-25; cirros dorsais com conspícua alternância no comprimento ao longo de todo o corpo; cirros ventrais digitiformes, ligeiramente mais curtos do que os lóbulos parapodiais. Parapódios com 3-4 acículas cada, na região anterior, algumas retas a levemente dobradas distalmente, outras subdistalmente infladas, com ponta oblíqua, 2 acículas por parapódio nas regiões mediana e posterior, uma reta e a outra ligeiramente inflada subdistalmente, com ponta oblíqua (Fig. 27E). Cerdas falcígeras com lâminas bidentadas, com dentes aproximadamente de mesmo tamanho e espinulação na lâmina e haste (Fig. 27A-B), as da região anterior medindo 37,5-10 $\mu \mathrm{m}, 30-20 \mu \mathrm{m}$ na mediana e 25-15 $\mu \mathrm{m}$ na posterior. Parapódios com 9-10 cerdas falcígeras na região anterior, 7-8 na mediana e 5-6 cerdas na posterior; cerdas simples dorsais e ventrais bidentadas, presentes na 
região posterior (Fig. 27C-D). Faringe ocupando 8-11 segmentos, com dente central grande e cônico, localizado na porção anterior, próximo à margem anterior. Proventrículo estendendo-se por 11-16 segmentos, com 35-35 feixes musculares.

Discussão: o padrão de pigmentação dorsal é um caráter determinante dentro do gênero. Apenas membros de três espécies apresentam esta coloração: $S$. corallicola, S. variegata Grube, 1860, e S. westheidei San Martín, 1984. Membros de $S$. corallicola diferem de exemplares de $S$. westheidei na morfologia das lâminas das cerdas falcígeras, com dentes grandes e aproximadamente do mesmo tamanho em membros de $S$. corallicola, o subdistal conspicuamente menor do que o distal em membros de $S$. westheidei. Com relação a exemplares de $S$. variegata, estes possuem cirros dorsais mais curtos e robustos, em relação aos de $S$. corallicola, e acículas de morfologia distinta, retas, pontiagudas e robustas.

Localidade-tipo: Ilhas Bermudas (Oceano Atlântico).

Distribuição: Mar Mediterrâneo, Ilhas Bermudas, Golfo do México, Cuba, Brasil (Bahia a São Paulo) (Oceano Atlântico).

Fig. 27- Syllis corallicola. A, cerdas falcígeras, região anterior; B, cerdas falcígeras, região posterior; $\mathbf{C}$, cerda simples dorsal; $\mathbf{D}$, cerda simples ventral; $\mathbf{E}$, acícula, região anterior. Barra de escala: $\mathrm{A}-\mathrm{E}=20 \mu \mathrm{m}$.

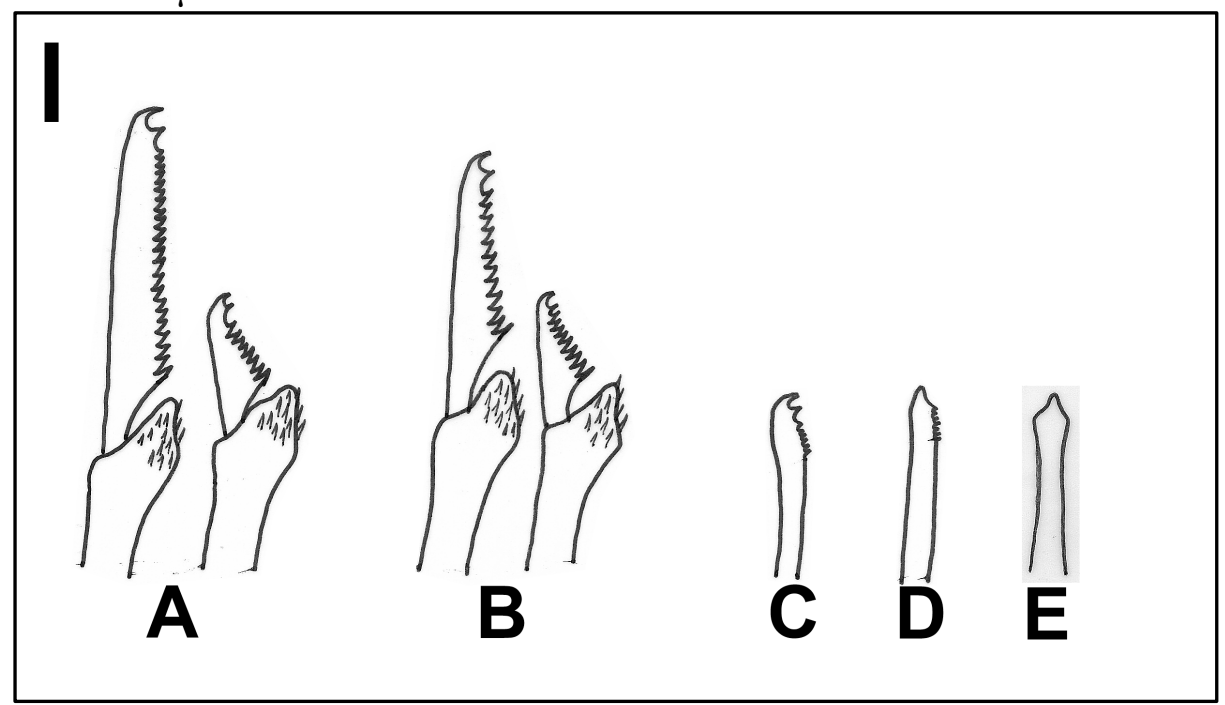

Fonte: Desenho de autoria própria. 


\section{Syllis hyllebergi (Licher, 1999)}

Fig. 28

Syllis hyllebergi NOGUEIRA \& SAN MARTÍN, 2002: 67-68, figs. 5-6; FUKUDA, 2010: 267-270.

Material analisado: São Sebastião - Praia Grande, em Caulerpa lentilifera: 5 esp., 13.Dez.2015; Praia Grande, em Hypnea musciform: 2 esp., 13.Dez.2015; Praia de São Francisco, em Hypnea musciform: 2 esp., 16.Jun.2015. Todos os indivíduos foram coletados na zona entremarés.

Descrição: animais de tamanho corpóreo pequeno a médio, com corpo subcilíndrico. Corpo com 1,55-7,55 mm de comprimento, 22-70 setígeros e 0,15-0,325 mm de largura. Prostômio ovalado, com 2 pares de olhos em trapézio e, geralmente, 1 par de manchas ocelares. Palpos alongados, distalmente arredondados, fundidos na porção basal. Antena mediana maior do que as laterais, com 9-20 artículos, inserida no centro do prostômio, entre o par de olhos anteriores; antenas laterais à frente da mediana, próximo às manchas ocelares, com 8-15 artículos. Peristômio menor do que os segmentos anteriores, cirros peristomiais dorsais aproximadamente do mesmo tamanho das antenas laterais, com 7-18 artículos, cirros peristomiais ventrais com 4-13 artículos, menores do que as antenas. Antenas, cirros peristomiais, dorsais ao longo do corpo e anais moniliformes; cirros dorsais do primeiro setígero ligeiramente maiores do que a antena mediana, com 23-25 artículos, cirros dorsais seguintes com 10-23 artículos, os da região mediana com 6-13 artículos e os posteriores; cirros dorsais com conspícua alternância no comprimento ao longo de todo o corpo; cirros ventrais digitiformes, do mesmo tamanho que os lóbulos parapodiais. Parapódios anteriores com 2 acículas na região anterior, infladas subdistalmente, com ponta oblíqua (Fig. 28E), 1 acícula por parapódio nas 
regiões mediana e posterior, com mesma morfologia. Cerdas falcígeras com lâminas bidentadas, com dentes de aproximadamente mesmo tamanho na região anterior, o subdistal progressivamente maior em direção posterior, com espinulação conspícua nas lâminas e nas hastes (Fig. 28 A-B), lâminas da região anterior medindo $15-7,5 \mu \mathrm{m}, 10-5 \mu \mathrm{m}$ na região mediana e $7,5-2,5 \mu \mathrm{m}$ na posterior; cerdas pseudoespinígeras presentes, com lâminas bidentadas e dentes de mesmo tamanho, lâminas medindo 50-45 $\mu \mathrm{m}$ na região anterior, 70-55 $\mu \mathrm{m}$ na mediana e 62,5-50 $\mu \mathrm{m}$ na posterior. Parapódios com 8-12 cerdas falcígeras e 1-3 pseudoespinígeras na região anterior, 5-8 falcígeras e 1-2 pseudoespinígeras na mediana e 4-7 falcígeras e 1 pseudoespinígera na posterior; cerdas simples dorsais e ventrais presentes na região posterior, as dorsais distalmente truncadas e bífidas, as ventrais bidentadas (Fig. 28C-D). Faringe ocupando 4-10 segmentos, com dente central grande e cônico, localizado na porção anterior, próximo à margem. Proventrículo estendendo-se por 4-6 segmentos, com 28-38 feixes musculares.

Discussão: Os espécimes analizados nesse estudo se assemelham aos descritos anteriormente para a costa brasileira (FUKUDA, 2010), assim como aos da descrição dada para espécimes do Mar Vermelho (LICHER, 1999), com 2 acículas na região anterior. Membros desta espécie se assemelham aos de $S$. yallingupensis (Hartmann-Schöder, 1982) na morfologia das falcígeras, sendo estas bidentadas, com dente subdistal progressivamente maior e com espinulação da lâmina voltada para cima. Contudo, o comprimento das antenas e cirros, a grossura das espinulações nas lâminas das falcígeras e a morfologia das acículas, são características que os distinguem, visto que em $S$. yallingupensis as antenas e cirros são mais longos, as espinhas nas lâminas das falcígeras são consideravelmente mais finas e as acículas não são tão infladas subdistalmente e são consideravelmente mais recurvadas.

Localidade-tipo: Egito, Dahab, Lagoa El Kura (Mar Vermelho).

Distribuição: Mar Vermelho; Brasil (São Paulo) (Oceano Atlântico). 
Fig. 28 - Syllis hyllebergi. A, cerdas pseudoespinígera e falcígera, região anterior; B, cerdas pseudoespinígera e falcígera, região posterior; $\mathbf{C}$, cerda simples dorsal; $\mathbf{D}$, cerda simples ventral; $\mathbf{E}$, acículas, região anterior. Barra de escala: $\mathrm{A}-\mathrm{E}=10 \mu \mathrm{m}$.

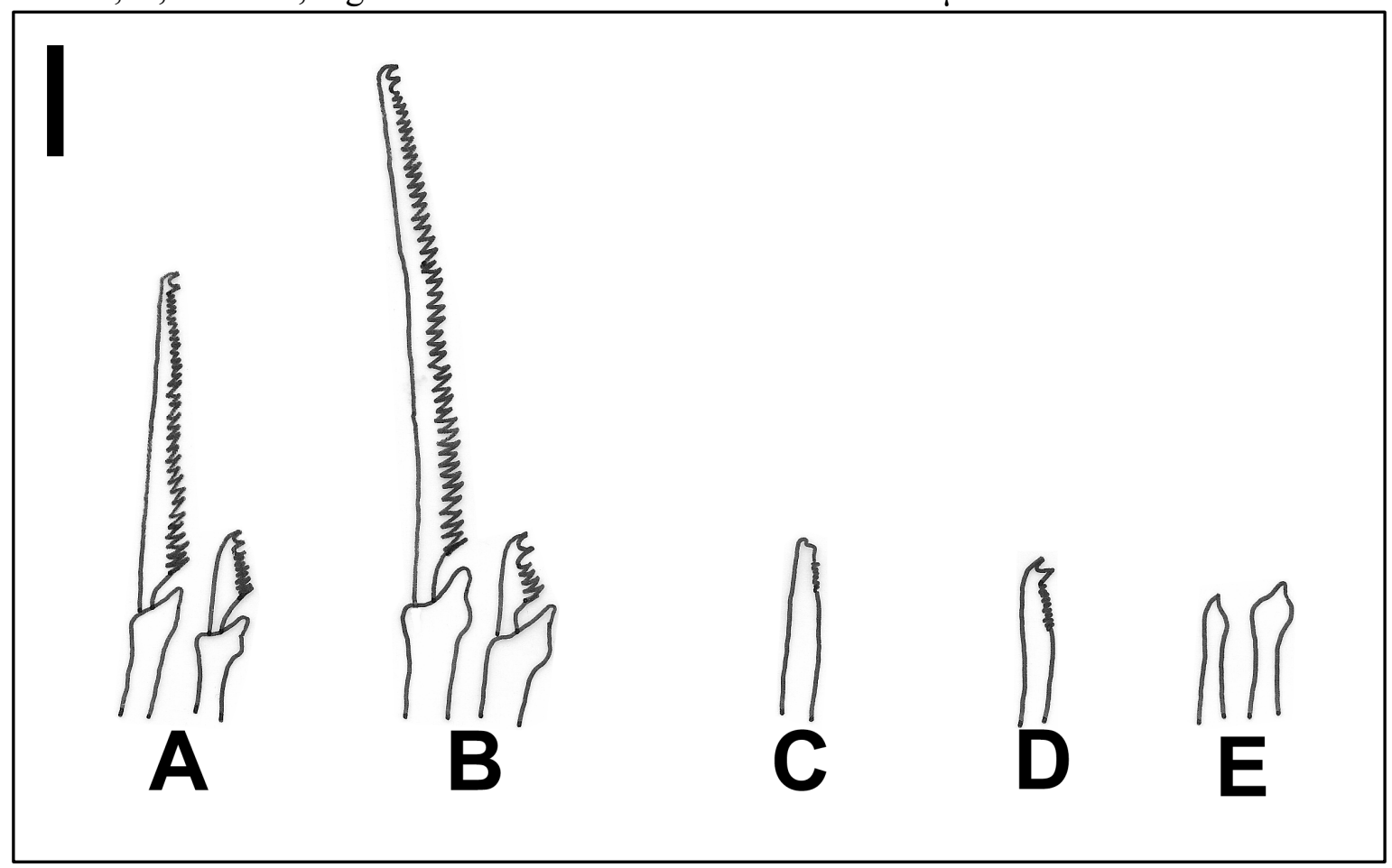

Fonte: Desenho de autoria própria.

\section{Syllis lutea (Hartmann-Schöder, 1960)}

Fig. 29

Syllis lutea NOGUEIRA \& SAN MARTÍN, 2002: 75-80, figs. 13-14; FUKUDA, 2010: 270273.

Material analisado: São Sebastião - Praia Grande, em Hypnea musciform: 1 esp., 13.Dez.2015. Coletado na zona entremarés.

Descrição: animal de tamanho corpóreo médio, com corpo subcilíndrico. Corpo com 6,125 mm de comprimento, 58 setígeros e 0,375 $\mathrm{mm}$ de largura. Prostômio ovalado, com 2 pares de olhos em trapézio e 1 par de manchas ocelares. Palpos ovais, com o ápice afilado, fundidos na porção basal. Antena mediana maior do que as laterais, com 24 artículos, inserida no centro do prostômio, entre o par de olhos anteriores; antenas laterais inseridas à frente da antena central, próximo à 
margem anterior, com 15 artículos. Peristômio menor do que os segmentos anteriores, cirros peristomiais dorsais de mesmo tamanho da antena mediana, com 24 artículos, cirros peristomiais ventrais com 14 artículos, aproximadamente do mesmo tamanho das antenas laterais. Antenas, cirros peristomiais, dorsais ao longo do corpo e anais moniliformes; cirros dorsais do primeiro setígero com o mesmo tamanho da antena mediana, com 24 artículos, cirros dorsais seguintes com 20 artículos, os da região mediana com 18 artículos e os posteriores, com 11; cirros dorsais com conspícua alternância no comprimento ao longo de todo o corpo; cirros ventrais digitiformes, pouco maiores do que os lóbulos parapodiais. Parapódios com 2 acículas cada na região anterior, uma inflada subdistalmente, com ponta oblíqua, a outra recurvada em ângulo de $90^{\circ} ; 1$ acícula por parapódio nas regiões mediana e posterior, com a mesma morfologia (Fig. 29E). Cerdas falcígeras com lâminas bidentadas, com dentes de aproximadamente mesmo tamanho na região anterior, o subdistal muito maior a partir da região mediana, com espinulação conspícua nas lâminas e nas hastes (Fig. 29A-B), cerdas da região anterior com lâminas medindo 32,5-12,5 $\mu \mathrm{m}, 25-10 \mu \mathrm{m}$ na região mediana e 22,5-10 $\mu \mathrm{m}$ na posterior. Parapódios com 10 cerdas falcígeras na região anterior, 8 na mediana e 5 falcígeras na posterior; cerdas simples dorsais e ventrais bidentadas, presentes na região posterior (Fig. 29C-D). Faringe ocupando cerca de 7 segmentos, com dente central grande e cônico, localizado na porção anterior, próximo da margem. Proventrículo estendendo-se por 4,5 segmentos, com 24 feixes musculares.

Discussão: do gênero em questão, membros de 6 espécies se assemelham ao animal descrito acima: S. magnipectinis Storch, 1967, S. ortizi San Martín, 1992, S. cruzi Núñez \& San Martín, 1991, S. glarearia (Westheide, 1974), S. guidae Nogueira \& Yunda-Guarin, 2008 e S. jorgei San Martín \& Lopez, 2000. Indivíduos das duas primeiras espécies se diferenciam do de $S$. lutea descrito acima por apresentarem lâminas das falcígeras com dente subdistal muito maior 
e mais robusto do que o distal, enquanto no animal acima o dente subdistal das lâminas das falcígeras é nitidamente maior do que o distal, mas a diferença entre eles não é tão marcada; as lâminas das cerdas falcígeras mais ventrais dos parapódios posteriores são mais robustas em membros de $S$. magnipectinis e de S. ortizi, em comparação com o espécime acima. Membros de $S$. cruzi possuem cirros dorsais menores do que os do animal acima, e a espinulação das lâminas de suas falcígeras é muito mais curta do que no animal acima. Membros de $S$. glarearia e de $S$. guidae apresentam lâminas das falcígeras mais curtas do que as do exemplar acima, com espinulação mais robusta, além dos espécimes de $S$. guidae também possuirem cirros dorsais mais curtos. Por último, membros de $S$. jorgei possuem lâminas das falcígeras com dente subdistal proporcionalmente menor do que o distal e espinulação mais alongada, em comparação com o espécime de $S$. lutea.

Localidade-tipo: Arábia Saudita, Ilha Sarso (Mar Vermelho).

Distribuição: Espécie circumtropical, com registros no Mar Vermelho (Oceano Índico); Japão e Austrália (Oceano Pacífico); Cuba e litoral paulista do Brasil (Oceano Atlântico).

Fig. 29 - Syllis lutea. A, cerdas falcígeras, região anterior; B, cerdas falcígeras, região posterior; $\mathbf{C}$, cerda simples dorsal; $\mathbf{D}$, cerda simples ventral; $\mathbf{E}$, acículas, região anterior. Barra de escala: $\mathrm{A}-\mathrm{E}=10 \mu \mathrm{m}$.

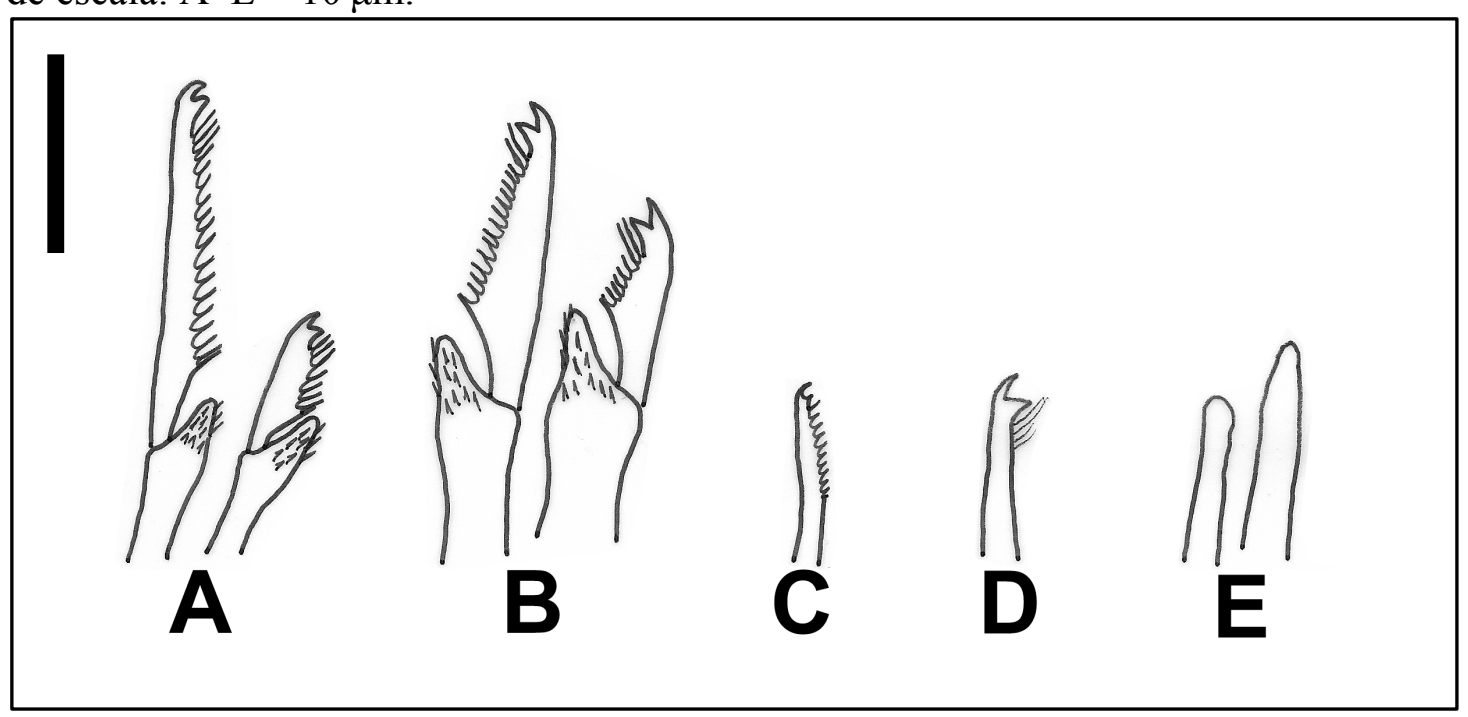

Fonte: Desenho de autoria própria. 


\section{Syllis prolifera Krohn, 1852}

Fig. 30

Syllis prolifera NOGUEIRA, 2000: 114, fig. 27G-L; 2006: 159; NOGUEIRA \& SAN MARTÍN, 2002: 72-73, figs. 9-10; FUKUDA, 2010: 283-286.

Material analisado: São Sebastião - Praia Grande, em Caulerpa lentilifera: 1 esp., 13.Dez.2015; Praia Grande, em Hypnea musciform: 1 esp., 13.Dez.2015; Praia Grande, em Caulerpa lentilifera: 4 esp., 30.Jun.2015. Todos os indivíduos foram coletados na zona entremarés.

Descrição: animais de tamanho corpóreo médio, com corpo subcilíndrico com pigmentação granular, entre castanho e vermelho escuro, distribuídos aleatoriamente pelo dorso, às vezes concentrada na base dos cirros; faringe vermelho escura, visível por transparência, através da parede do corpo. Corpo com 2,5-6,75 $\mathrm{mm}$ de comprimento, 30-76 setígeros e 0,175-0,75 $\mathrm{mm}$ de largura. Prostômio ovalado, com 2 pares de olhos em trapézio e, geralmente, 1 par de manchas ocelares. Palpos triangulares, fundidos na região basal. Antena mediana maior do que as laterais, com 23-32 artículos, inserida no centro do prostômio, entre o par de olhos anteriores; antenas laterais à frente da mediana, próximo às manchas ocelares, com 14-20 artículos. Peristômio menor do que os segmentos anteriores, cirros peristomiais dorsais pouco menores que a antena mediana, com 16-30 artículos, cirros peristomiais ventrais com 13-18 artículos, aproximadamente do mesmo tamanho das antenas laterais. Antenas, cirros peristomiais, dorsais ao longo do corpo e anais moniliformes; cirros dorsais do primeiro setígero mais longos do que a antena mediana, com 41-43 artículos, cirros dorsais seguintes com 15-40 artículos, os da região mediana com 15-32 artículos e os posteriores, com 11-28; cirros dorsais com conspícua alternância no comprimento ao longo de todo o corpo; cirros ventrais digitiformes, do mesmo tamanho dos lóbulos parapodiais. Parapódios anteriores com até 3 
acículas na região anterior, infladas subdistalmente, ponta afilada oblíqua; 2 acículas por parapódio na região mediana e 1 na posterior, com morfologia distinta, distalmente inflada e oca, assemelhando-se a uma colher (Fig. 30E). Cerdas falcígeras com lâminas bidentadas, com dente distal maior do que o subdistal na região anterior, dentes de aproximadamente mesmo tamanho, a partir da região mediana do corpo, com espinulação conspícua nas lâminas e nas hastes (Fig. 30A-B); lâminas da região anterior medindo 35-20 $\mu \mathrm{m}, 27,5-15$ $\mu \mathrm{m}$ na região mediana e $25-7,5 \mu \mathrm{m}$ na posterior. Parapódios com 10-12 cerdas falcígeras na região anterior, 6-9 na mediana e 4-6 na posterior; cerdas simples dorsais e ventrais bidentadas, presentes na região posterior (Fig. 30C-D). Faringe ocupando 4-12 segmentos, com dente central grande e cônico, localizado na porção anterior, ligeiramente afastado da margem. Proventrículo estendendo-se por 3-10 segmentos, com 24-50 feixes musculares.

Discussão: membros de apenas duas outras espécies do gênero apresentam morfologia similar das acículas em comparação com a espécie descrita acima: $S$. vivipara Krohn, 1869 e S. prolixa Ehlers, 1901. Exemplares de ambas as espécies, todavia, possuem falcigeras com lâminas unidentadas ou subbidentadas, com o dente subdistal diminuto, enquanto em membros de $S$. prolifera o dente subdistal é conspícuo, aproximadamente de mesmo tamanho do distal, a partir da região mediana do corpo. Além disso, exemplares de $S$. vivipara têm antenas e cirros peristomiais e dorsais ao longo do corpo mais curtos do que os de $S$. prolifera, enquanto os de $S$. prolixa têm lâminas das falcígeras com espinulação mais robusta.

Localidade-tipo: França, Villefranche-sur-mer (Mar Mediterrâneo).

Distribuição: Espécie cosmopolita, com registros Mar Mediterrâneo (Adriático e Egeu), Américas, África, Europa e Brasil (Oceano Atlântico), bem como o litoral da Ocêania (Oceano Pacífico). 
Fig. 30 - Syllis prolifera. A, cerdas falcígeras, região anterior; $\mathbf{B}$, cerdas falcígeras, região posterior; $\mathbf{C}$, cerda simples dorsal; $\mathbf{D}$, cerda simples ventral; $\mathbf{E}$, acícula, região posterior. Barra de escala: $\mathrm{A}-\mathrm{E}=10 \mu \mathrm{m}$.

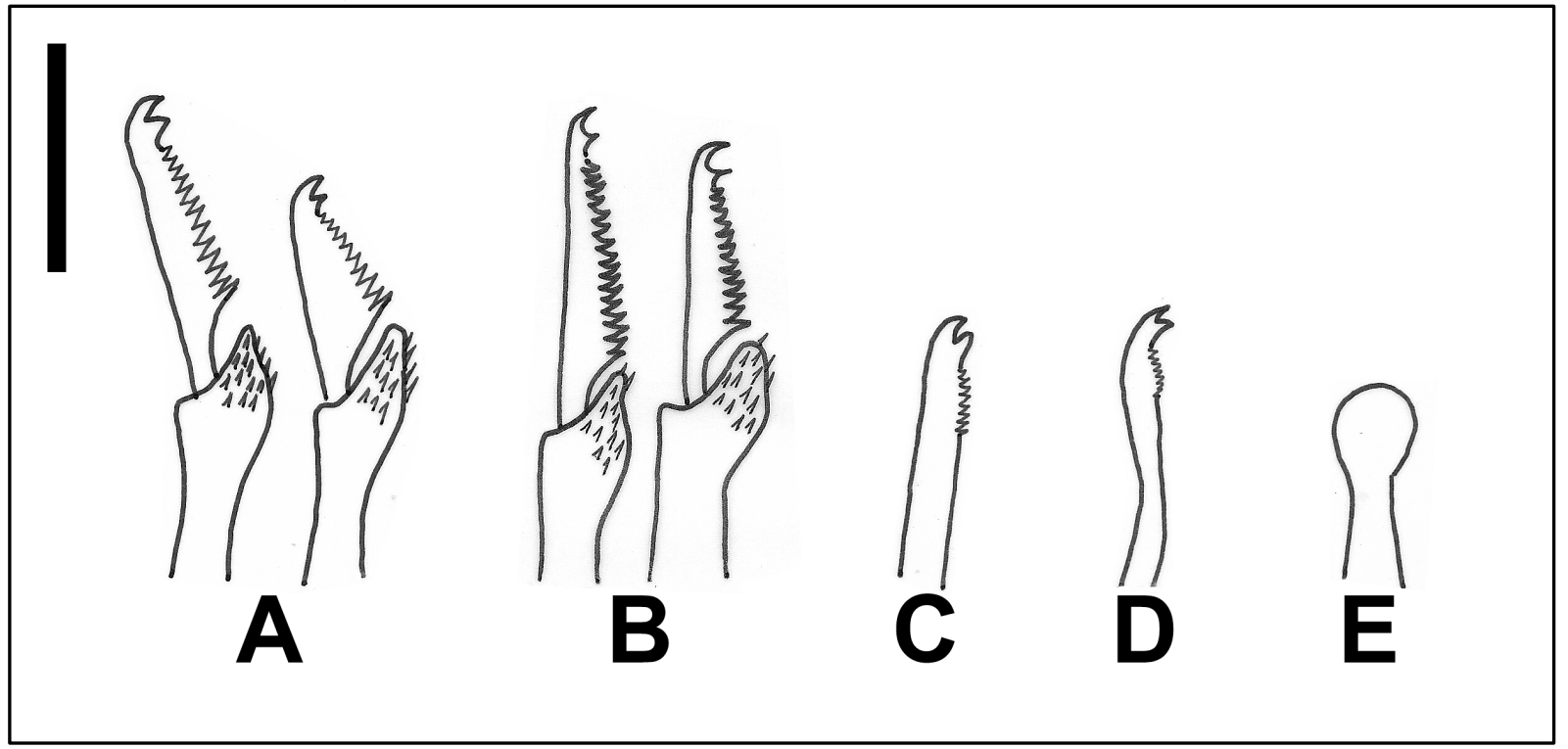

Fonte: Desenho de autoria própria.

\section{Syllis pseudoarmillaris Nogueira \& San Martín, 2002}

Fig. 31

Syllis pseudoarmillaris NOGUEIRA \& SAN MARTÍN, 2002: 83-85, figs. 17-18; NOGUEIRA, 2006: 160; FUKUDA, 2010: 286-289.

Material analisado: São Sebastião - Praia Grande, em Caulerpa lentilifera: 3 esp., 13.Dez.2015; Praia da Baleia, em Caulerpa lentilifera: 2 esp., 08.Abr.2016; Praia da Baleia, em Dyctiota ciliolata: 1 esp., 08.Abr.2016; Praia de São Fracisco, em Sargassum sp.: 1 esp., 16.Jun.2015. Todos os indivíduos foram coletados na zona entremarés.

Descrição: animais de tamanho corpóreo pequeno a médio, com corpo subcilíndrico com pigmentação escura no dorso, entre marrom e avermelhado, com 1 faixa transversal mediana nos setígeros. Corpo com 1,875-5,375 mm de comprimento, 19-60 setígeros e 0,125-0,375 mm de largura. Prostômio 
ovalado, com 2 pares de olhos em trapézio e 1 par de manchas ocelares. Palpos ovalados, levemente afilados distalmente, fundidos na porção basal. Antena mediana maior do que as laterais, com 10-12 artículos, inserida no centro do prostômio, entre o par de olhos posteriores; antenas laterais à frente da mediana, próximo à margem anterior, com 6-10 artículos. Peristômio menor do que os segmentos anteriores, cirros peristomiais dorsais maiores do que as antenas, com 7-21 artículos, cirros peristomiais ventrais com 6-10 artículos, do mesmo tamanho das antenas laterais. Antenas, cirros peristomiais, dorsais ao longo do corpo e anais moniliformes; cirros dorsais do primeiro setígero ligeiramente mais longos do que as antenas, com 14-16 artículos, cirros dorsais seguintes com 7-14 artículos, os da região mediana com 5-14 artículos e os posteriores, com 4-12; cirros dorsais com conspícua alternância no comprimento ao longo de todo o corpo; cirros ventrais ovalados, de mesmo comprimento dos lóbulos parapodiais. Parapódios com 2-3 acículas cada, na região anterior, infladas subdistalmente, com ponta afilada oblíqua (Fig. 31E); 1-2 acículas na região mediana e 1 na posterior, com a mesma morfologia. Cerdas falcígeras com lâminas bidentadas, com dente distal ligeiramente maior do que subdistal e espinulação conspícua nas lâminas e nas hastes (Fig. 31A-B), lâminas da região anterior medindo $32,5-10 \mu \mathrm{m}, 25-7,5 \mu \mathrm{m}$ na região mediana e $25-5 \mu \mathrm{m}$ na posterior. Parapódios com 7-12 cerdas falcígeras cada na região anterior, 3-9 na mediana e 3-5 na posterior; cerdas simples dorsais e ventrais bidentadas, presentes na região posterior do corpo (Fig. 31C-D). Faringe ocupando cerca de 4-7 segmentos, com dente central grande e cônico, localizado na porção anterior, mais próximo da margem. Proventrículo estendendo-se por 4-6 segmentos, com 25-46 feixes musculares.

Discussão: membros de $S$. pseudoarmillaris se assemelham aos de S. armillaris (Müller, 1776) e S. hyalina Grube, 1863 no tamanho e formato das antenas, cirros peristomiais e dorsais ao longo do corpo, bem como no formato das cerdas simples dorsais e ventrais, e das acículas. Entretanto, membros de $S$. 
armillaris apresentam lâminas das falcígeras sub-bidentadas, com dente subdistal diminuto, ou unidentadas, enquanto em exemplares de $S$. pseudoarmillaris as lâminas são bidentadas, com dente subdistal menor do que o distal, mas ambos conspícuos. Por outro lado, em membros de $S$. hyalina os dentes das lâminas das falcígeras são de mesmo tamanho, além de também apresentarem acículas mais robustas, com a ponta protraindo dos lóbulos parapodiais, o que não ocorre em exemplares de $S$. pseudoarmillaris.

Localidade-tipo: Brasil, costa do Estado de São Paulo, Laje dos Santos (24 19' $\left.\mathrm{S}, 46^{\circ} 11^{\prime} \mathrm{O}\right)$.

Distribuição: Brasil (São Paulo) (Oceano Atlântico).

Fig. 31 - Syllis pseudoarmillaris. A, cerdas falcígeras, região anterior; $\mathbf{B}$, cerdas falcígeras, região posterior; $\mathbf{C}$, cerda simples dorsal; $\mathbf{D}$, cerda simples ventral; $\mathbf{E}$, acículas, região anterior. Barra de escala: A-E $=10 \mu \mathrm{m}$.

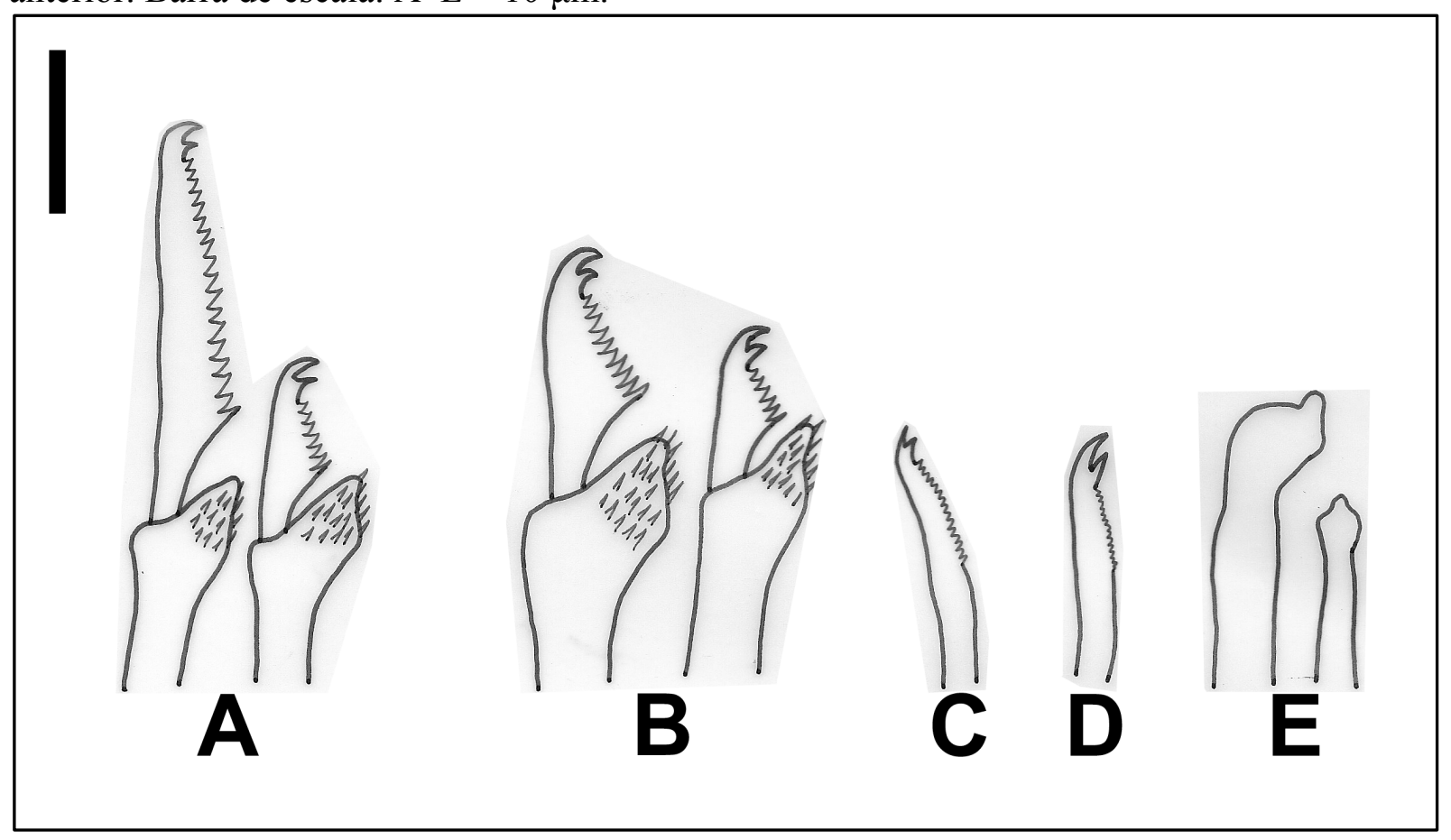

Fonte: Desenho de autoria própria. 


\section{Syllis rosea (Langerhans, 1879)}

Fig. 32

Syllis rosea SAN MARTíN, 2003: 358-361, figs. 194-195; FUKUDA, 2010: 289-294, figs. 76-77.

Material analisado: São Sebastião - Praia da Baleia, em Dyctiota ciliolata: 1 esp., 08.Abr.2016. Coletado na zona entremarés.

Descrição: animal de tamanho corpóreo pequeno, com corpo subcilíndrico proporcionalmente longo e fino. Corpo com 1,25 mm de comprimento, 24 setígeros e 0,175 $\mathrm{mm}$ de largura. Prostômio ovalado, com 2 pares de olhos em trapézio, manchas ocelares ausentes. Palpos ovais, distalmente afilados, fundidos na porção basal. Antena mediana maior do que as laterais, com 10 artículos, inserida no centro do prostômio, entre o par de olhos posteriores; antenas laterais inseridas à frente da antena central, próximo à margem anterior, com $\sim 8$ artículos. Peristômio menor do que os segmentos anteriores, cirros peristomiais dorsais aproximadamente do mesmo tamanho da antena mediana, com 9 artículos, cirros peristomiais ventrais com 7 artículos, aproximadamente de mesmo tamanho das antenas laterais. Antenas, cirros peristomiais, dorsais ao longo do corpo e anais moniliformes; cirros dorsais do primeiro setígero ligeiramente mais longos, com 7-9 artículos, cirros dorsais seguintes com 5-7 artículos, os da região medianas com 4-5 artículos e os posteriores, com 3-4; cirros dorsais com conspícua alternância no comprimento ao longo de todo o corpo; cirros ventrais digitiformes, com mesmo comprimento dos lóbulos parapodiais. Parapódios com 3 acículas na região anterior, 1 acícula por parapódio, a partir da região mediana, subdistalmente dobradas em ângulo reto (Fig. 32E). Cerdas pseudoespinígeras presentes, 1-2 por parapódio, nas regiões anterior e mediana, apenas 1 por parapódio na região posterior, com lâminas bidentadas na região anterior e unidentadas a partir da região mediana, com 
espinulação conspícua nas lâminas e nas hastes, medindo $50-25 \mu \mathrm{m}$ na região anterior, 40-17,5 $\mu \mathrm{m}$ na região mediana e $25-15 \mu \mathrm{m}$ na região posterior (Fig. 32A-B). Cerdas falcígeras com lâminas bidentadas, com dente distal maior do que o subdistal, e espinulação conspícua nas lâminas e nas hastes (Fig. 32A-B); lâminas das cerdas da região anterior medindo $20,5-17,5 \mu \mathrm{m}, 18-15 \mu \mathrm{m}$ na região mediana e 15-10 $\mu \mathrm{m}$ na posterior. Parapódios com 10 cerdas falcígeras cada na região anterior, 7 na mediana e 5 na posterior; cerdas simples dorsais ligeiramente inclinadas e truncadas, distalmente bífidas, presentes a partir da região mediana; cerdas simples ventrais bidentadas, presentes a partir da região posterior (Fig. 32C-D). Faringe ocupando 6 segmentos, com dente central grande e cônico, localizado na porção anterior, mais próximo da margem. Proventrículo estendendo-se por 5 segmentos, com 25 feixes musculares.

Discussão: o animal coletado se assemelha a membros de $S$. maryae San Martín, 1992, por apresentar cerdas pseudoespinígeras, cerdas falcígeras bidentadas e acículas recurvadas em ângulo reto. Ele difere de membros daquela espécie, todavia, por apresentar espinulação das lâminas das cerdas mais robusta, por ter pseudoespinígeras uni- e bidentadas, dependendo da região do corpo, e por não ter glândulas dorsais, estando estas presentes em membros de $S$. maryae, cujas cerdas pseudoespinígeras são todas unidentadas. Por isto, este exemplar está de acordo com a descrição de $S$. rosea.

Localidade-tipo: Portugal, Ilha da Madeira (Oceano Atlântico).

Distribuição: Cosmopolita, com registros no Japão (Oceano Pacífico); Mar Vermelho (Oceano Índico); Espanha (do norte do país às Ilhas Canárias), Brasil (São Paulo) (Oceano Atlântico). 
Fig. 32 -Syllis rosea. A, cerdas pseudoespinígera e falcígeras, região anterior; $\mathbf{B}$, cerdas pseudoespinígera e falcígeras, região posterior; $\mathbf{C}$, cerda simples dorsal; $\mathbf{D}$, cerda simples ventral; E, acículas, região anterior. Barra de escala: A-E $=40 \mu \mathrm{m}$.

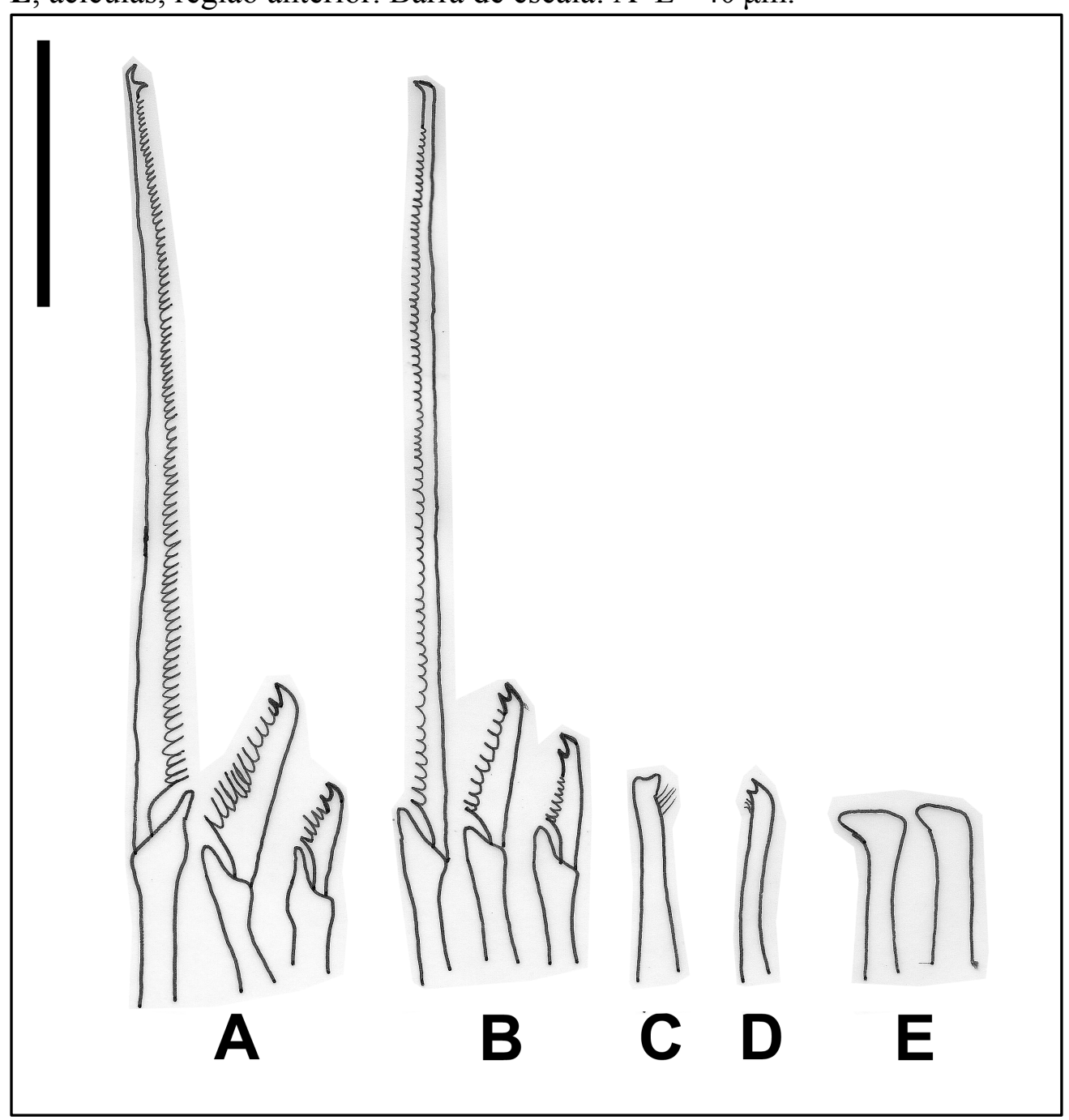

Fonte: Desenho de autoria própria.

\section{Syllis truncata Haswell, 1920}

Fig. 33

Syllis truncata NOGUEIRA \& SAN MARTÍN, 2002: 89-91, fig. 21; FUKUDA, 2010: 297299.

Material analisado: São Sebastião - Praia Grande, em Caulerpa lentilifera: 1 esp., 13.Dez.2015; Praia Grande, em Hypnea musciform: 1 esp., 13.Dez.2015; Praia da Baleia, em Caulerpa lentilifera: 2 esp., 08.Abr.2015; Praia da Baleia, 
em Dyctiota ciliolata: 6 esp., 08.Abr.2015; Praia de São Francisco, em Hypnea musciform: 6 esp., 16.Jun.2015. Todos os indivíduos foram coletados na zona entremarés.

Descrição: animais de tamanho corpóreo médio, com corpo subcilíndrico. Corpo com 1,25-7,25 $\mathrm{mm}$ de comprimento, 27-88 setígeros e 0,175-0,4 $\mathrm{mm}$ de largura. Prostômio ovalado, mais curto do que os palpos, com 2 pares de olhos em trapézio. Palpos ovalados e curtos, fundidos na região basal. Antena mediana maior do que as laterais, com 17-35 artículos, inserida no centro do prostômio, entre o par de olhos posteriores; antenas laterais à frente da mediana, próximo aos olhos anteriores, com 5-18 artículos. Peristômio de mesmo tamanho dos segmentos anteriores, cirros peristomiais dorsais com mesmo tamanho da antena mediana, com 18-34 artículos, cirros peristomiais ventrais com 5-18 artículos, mesmo tamanho das antenas laterais. Antenas, cirros peristomiais, dorsais ao longo do corpo e anais moniliformes; cirros dorsais do primeiro setígero ligeiramente maiores do que as antenas, com 40-42 artículos, cirros dorsais seguintes com 8-38 artículos, os da região mediana com 6-25 artículos e os posteriores, com 18-4; cirros dorsais com conspícua alternância no comprimento ao longo de todo o corpo; cirros ventrais digitiformes, de mesmo tamanho dos lóbulos parapodiais. Parapódios com 2 acículas cada na região anterior, 1-2 por parapódio a partir da região mediana, subdistalmente dobradas em ângulo reto (Fig. 33E). Cerdas falcígeras com lâminas bidentadas, com dente distal ligeiramente maior do que o subdistal, e conspícua espinulação nas lâminas e nas hastes (Fig. 33A-B), lâminas das cerdas da região anterior medindo 37,5-7,5 $\mu \mathrm{m}, 32,5-5 \mu \mathrm{m}$ na mediana e $27,5-5 \mu \mathrm{m}$ na posterior. Parapódios apresentando com 5-14 cerdas falcígeras cada na região anterior, 410 na mediana e 4-8 na posterior; cerdas simples dorsais e ventrais, presentes na região posterior, as dorsais distalmente truncadas e bífidas, as ventrais bidentadas (Fig. 33C-D). Faringe ocupando 4-8 segmentos, com dente central 
grande e cônico, localizado na porção anterior, mais próximo da margem. Proventrículo estendendo-se por 3-8 segmentos, com 23-48 feixes musculares. Discussão: membros de três outras espécies de Syllis se assemelham aos animais descritos acima, por possuírem lâminas das falcígeras bidentadas e morfologia das acículas similar, dobradas em ângulo reto, S. gerlachi (Hartmann-Schöder, 1960), S. rosea (Langerhans,1879) e S. tyrrhena (Licher \& Kuper,1998), ambas as últimas já registradas no Brasil (FUKUDA, 2010; NOGUEIRA \& SAN MARTÍN, 2002). Membros de S. gerlachi se diferenciam dos animais descritos acima por terem lâminas das falcígeras mais curtas e pela espinulação das lâminas das falcígeras ser mais conspícua, bem como os dentes; além disso as cerdas simples ventrais de animais desta espécie são unidentadas. Membros de $S$. rosea se distinguem principalmente pela presença de cerdas pseudoespinígeras, o que não observamos em $S$. truncata. Já exemplares de $S$. tyrrhena diferem dos descritos acima por serem animais de menor porte, com corpo fino e proporcionalmente alongado, e possuírem lâminas das falcígeras mais curtas.

Localidade-tipo: Austrália, Port Jackson (Oceano Pacífico).

Distribuição: Austrália e Chile (Oceano Pacífico). Brasil (São Paulo) (Oceano Atlântico). 
Fig. 33 - Syllis truncata. A, cerdas falcígeras, região anterior; B, cerdas falcígeras, região posterior; $\mathbf{C}$, cerda simples dorsal; $\mathbf{D}$, cerda simples ventral; $\mathbf{E}$, acículas, região anterior. Barra de escala: $\mathrm{A}-\mathrm{D}=10 \mu \mathrm{m} ; \mathrm{E}=5 \mu \mathrm{m}$.

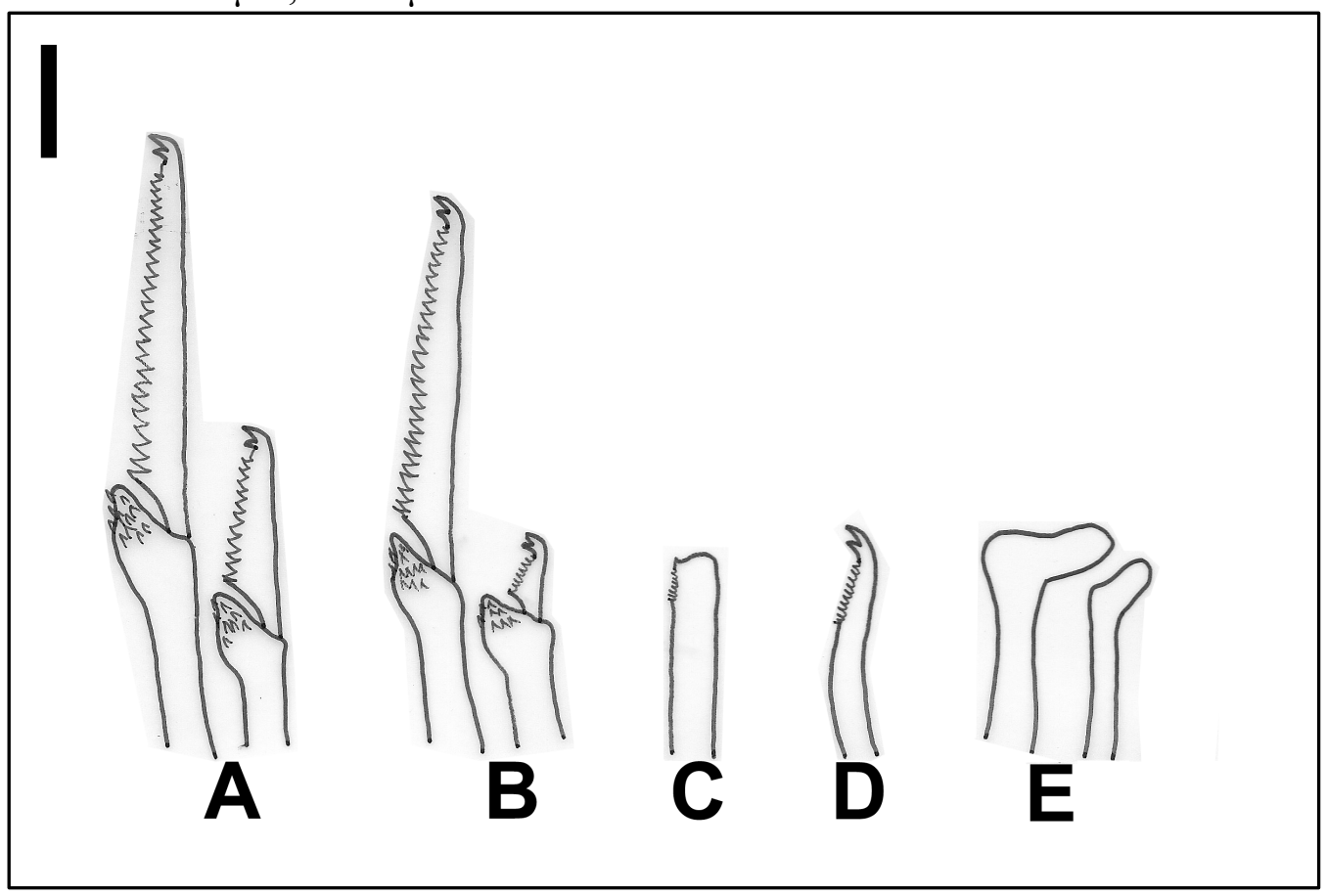

Fonte: Desenho de autoria própria.

\section{Syllis westheidei San Martín, 1984}

Fig. 34

Syllis westheidei SAN MARTÍN, 2003: 436-439, fig. 240-241; FUKUDA, 2010: 299-303, fig. 79.

Material analisado: São Sebastião - Praia da Baleia, em Caulerpa lentilifera: 1 esp., 08.Abr.2015; Praia Grande, em Caulerpa lentilifera: 1 esp., 30.Jun.2015. Ambos os indivíduos foram coletados na zona entremarés.

Descrição: animais de tamanho corpóreo médio, com corpo subcilíndrico, robusto e com pigmentação escura no dorso, castanha a avermelhada, em linhas transversais que delimitam uma área despigmentada em forma de " 8 " transversal, padrão conhecido como pigmentação "tipo-variegata". Corpo com 1,55-5,5 mm de comprimento, 24-63 setígeros e 0,125-0,35 $\mathrm{mm}$ de largura. 
Prostômio ovalado, com 2 pares de olhos em trapézio e 1 par de manchas ocelares. Palpos triangulares alongados, distalmente arredondados, fundidos na porção basal. Antena mediana maior do que as laterais, com 16-40 artículos, inserida no centro do prostômio, entre o par de olhos posteriores; antenas laterais à frente da mediana, próximo aos olhos anteriores, com 9-32 artículos. Peristômio menor do que os segmentos anteriores, cirros peristomiais dorsais aproximadamente de mesmo tamanho das antenas laterais, com 12-30 artículos, cirros peristomiais ventrais menores, com 8-22 artículos. Antenas, cirros peristomiais, dorsais ao longo do corpo e anais moniliformes; cirros dorsais do primeiro setígero mais longos do que as antenas, com 54-56 artículos, cirros dorsais seguintes com 16-54 artículos, os da região mediana com 8-32 artículos e os posteriores, com 6-26; cirros dorsais com conspícua alternância no comprimento ao longo de todo o corpo; cirros ventrais digitiformes, de mesmo tamanho dos lóbulos parapodiais. Parapódios com 3-4 acículas cada na região anterior, subdistalmente infladas, com pontas oblíquas (Fig. 34F), 3 acículas por parapódio na região mediana e 1 na posterior, com mesma morfologia. Cerdas falcígeras com lâminas bidentadas, com dente subdistal menor e menos robusto do que o distal, e conspícua espinulação nas lâminas e nas hastes (Fig. 34A-C); lâminas das cerdas da região anterior medindo 27,5-7,5 $\mu \mathrm{m}, 22,5-7,5 \mu \mathrm{m}$ na região mediana e 17,5-5 $\mu \mathrm{m}$ na posterior. Parapódios com 7-9 cerdas falcígeras na região anterior, 5-6 na mediana e 4-5 na posterior; cerdas simples dorsais e ventrais bidentadas, presentes na região posterior (Fig. 34D-E). Faringe ocupando 4-5 segmentos, com dente central grande e cônico, localizado na porção anterior, mais próximo da margem. Proventrículo estendendo-se por 2-6 segmentos, com 21-28 feixes musculares.

Discussão: membros desta espécie se assemelham muito aos de $S$. corallicola Verrill, 1900 (Ver "Discussão" em S. corallicola) e a S. variegata Grube, 1860, por apresentarem pigmentação "tipo variegata". Membros de S. variegata, além da pigmentação, também compartilham com os animais descritos acima a 
morfologia das antenas, dos cirros peristomiais e dorsais ao longo do corpo, mas eles diferem porque as acículas de exemplares de $S$. variegata protraem dos lóbulos parapodiais, o que não ocorre nos animais descritos acima. Todas estas características estão de acordo com a descrição de $S$. westheide.

Localidade-tipo: Espanha (Ilhas Baleares, Mar Mediterrâneo, Oceano Atlântico).

Distribuição: Ilhas Galápagos (Oceano Pacífico). Mar Mediterrâneo, Brasil (São Paulo) (Oceano Atlântico).

Fig. 34 - Syllis westheidei. A, cerdas falcígeras, região anterior; $\mathbf{B}$, cerdas falcígeras, região mediana; $\mathbf{C}$, cerda falcígeras, região posterior; $\mathbf{D}$, cerda simples dorsal; $\mathbf{E}$, cerda simples ventral; F, acículas, região anterior. Barra de escala: $\mathrm{A}-\mathrm{F}=10 \mu \mathrm{m}$.

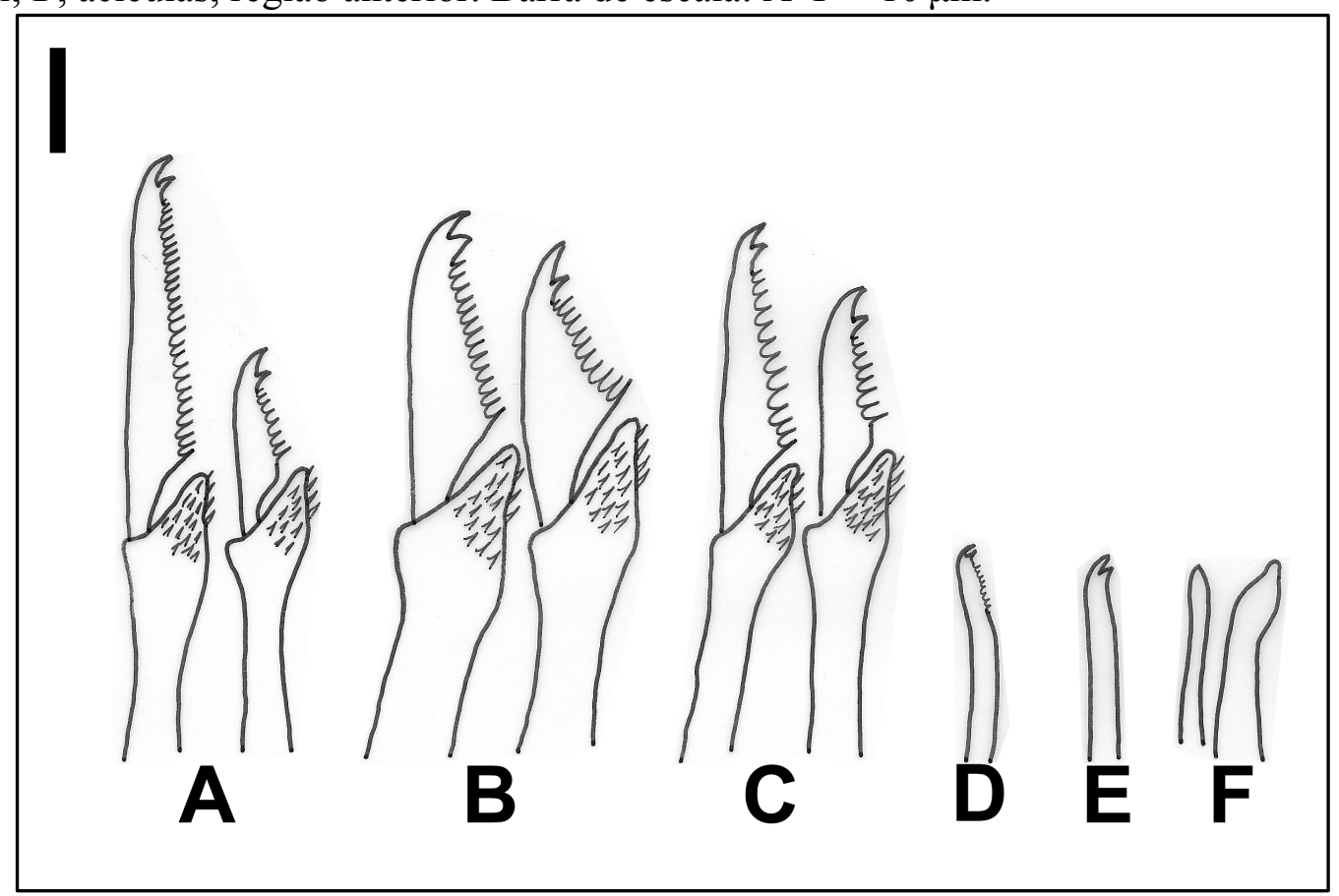

Fonte: Desenho de autoria própria.

\section{Syllis sp. 1 sp. nov.}

Figs. 35, 36

Material analisado: São Sebastião - Praia de São Francisco, em Hypnea musciform: 6 esp., 16.Jun.2015; Praia Grande, em Caulerpa lentilifera: 2 esp., 
30.Jun.2015. Todos os indivíduos foram coletados na zona entremarés.

Descrição: animais de tamanho corpóreo médio a grande, com corpo subcilíndrico com pigmentação escura no dorso, como uma faixa transversal central no dorso, conspícua apenas nos segmentos anteriores, até a região do proventrículo. Corpo com $0,8-8,75 \mathrm{~mm}$ de comprimento, 11-89 setígeros e 0,25-0,4 mm de largura. Prostômio ovalado, com 2 pares de olhos em trapézio, manchas ocelares ausentes. Palpos alongados, distalmente arredondados, de mesmo comprimento do prostômio, fundidos na porção basal. Antena mediana maior do que as laterais, com 10-16 artículos, inserida no centro do prostômio, entre o par de olhos anteriores; antenas laterais à frente da antena central, próximo à margem anterior, com 7-10 artículos. Peristômio menor do que os segmentos anteriores, cirros peristomiais dorsais quase do mesmo tamanho da antena mediana, com 9-14 artículos, cirros peristomiais ventrais com 6-10 artículos, aproximadamente o mesmo comprimento das antenas laterais. Antenas, cirros peristomiais, dorsais ao longo do corpo e anais moniliformes (Fig. 36A); cirros dorsais do primeiro setígero ligeiramente mais compridos do que as antenas, com 16-18 artículos, cirros dorsais seguintes com 10-16 artículos, os da região mediana com 7-10 artículos e os posteriores, com 5-8; cirros dorsais com conspícua alternância no comprimento ao longo de todo o corpo; cirros ventrais digitiformes, ligeiramente mais curtos do que os lóbulos parapodiais. Parapódios com 3 acículas cada, na região anterior, 2 acículas por parapódio na região mediana e 1 na posterior, subdistalmente dobradas em ângulo reto. Cerdas falcígeras com lâminas bidentadas, com dentes de aproximadamente mesmo tamanho, e conspícua espinulação nas lâminas e nas hastes (Fig. 35B; 36B-C), lâminas das cerdas da região anterior medindo 37,5$15 \mu \mathrm{m}, 32,5-7,5 \mu \mathrm{m}$ na mediana e 32,5-7,5 $\mu \mathrm{m}$ na posterior. Parapódios com $7-$ 12 cerdas falcígeras cada na região anterior, 5-10 na mediana e 4-6 na posterior; cerdas simples dorsais e ventrais bidentadas, presentes na região posterior (Fig. 
35C). Pigídio com cirros anais com aproximadamente 12 artículos cada (Fig. 35A). Faringe ocupando 5-9 segmentos, com dente central grande e cônico, localizado na porção anterior, mais próximo da margem. Proventrículo estendendo-se por 4-8 segmentos, com 32-44 feixes musculares.

Discussão: os espécimes descritos se assemlelham muito a membros de $S$. pseudoarmillaris, pelo padrão de coloração e morfologia dos apêndices (antenas e cirros) ao longo do corpo. Contudo, em membros de Syllis sp. 1 sp. nov. o proventrículo é normalmente maior, as cerdas falcígeras têm lâminas mais longas em todas as regiões do corpo e a espinulação das cerdas é mais robusta.

Fig. 35 - Syllis sp.1 sp. nov. A, pígidio e cirros anais; $\mathbf{B}$, cerdas falcígeras, região posterior; C, cerda simples dorsal. Barras de escala: $A=50 \mu \mathrm{m} ; B=2 \mu \mathrm{m} ; \mathrm{C}=10 \mu \mathrm{m}$.
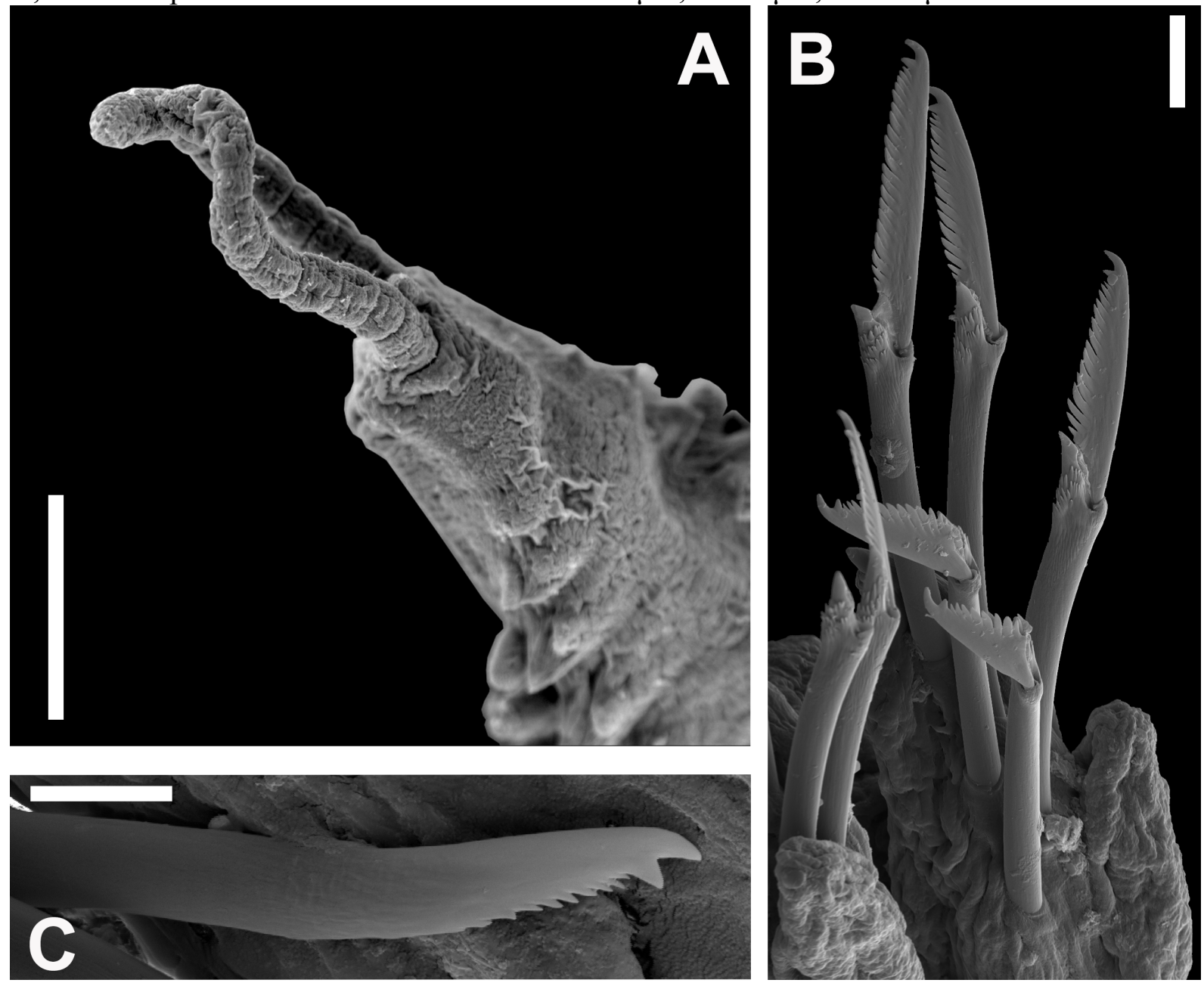

Fonte: MEV de autoria própria. 
Fig. 36 - Syllis sp.1. A, região anterior, vista dorsal; B, cerdas falcígeras, região anterior; $\mathbf{C}$, cerdas falcígeras, região posterior. Barra de escala: $\mathrm{A}=0,2 \mathrm{~mm} ; \mathrm{B}-\mathrm{C}=20 \mu \mathrm{m}$.

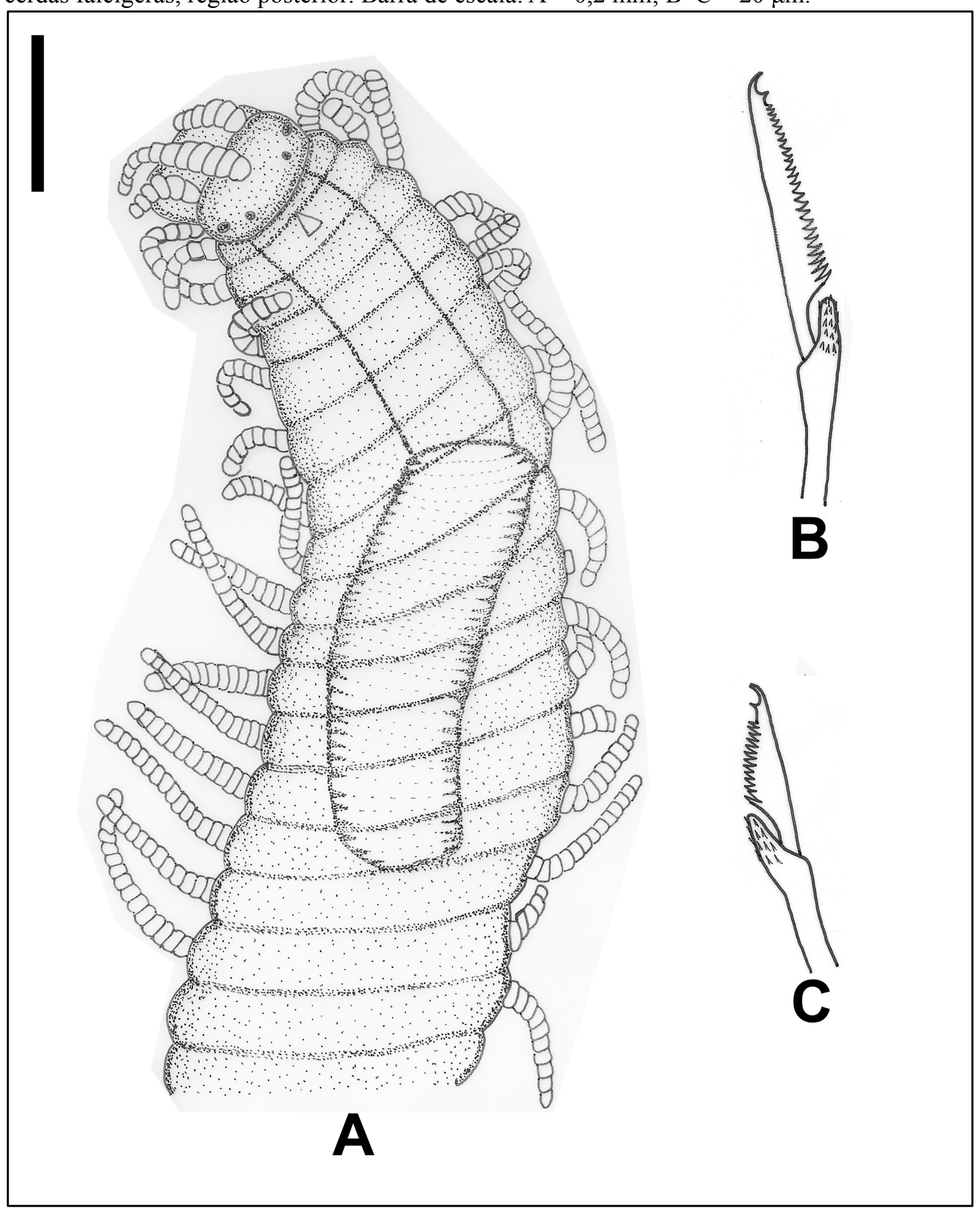

Fonte: Desenho de autoria própria.

Gênero Trypanosyllis Claparède, 1864

Espécie-tipo: Syllis zebra Grube, 1860. 
Diagnose: animais de tamanho corpóreo médio a grande, com corpo achatado dorso-ventralmente, podendo ou não apresentar padrão característico de pigmentação. Prostômio com 2 pares de olhos, por vezes também com 1 par de manchas ocelares, 3 antenas e 1 par de palpos desenvolvidos e completamente separados. Peristômio com 2 pares de cirros peristomiais. Antenas, cirros peristomiais, dorsais ao longo do corpo e anais moniliformes, podendo apresentar pigmentação. Cerdas pseudoespinígeras ausentes, cerdas falcígeras por vezes secundariamente simples; cerdas simples dorsais e ventrais podem estar presentes na região posterior. Faringe com trépano na margem anterior, podendo também apresentar um dente central.

Comentários: o gênero conta com 40 espécies descritas, 4 das quais já registradas no litoral brasileiro, sendo estas: T. aurantiacus Nogueira \& Fukuda, 2008 (FUKUDA, 2010), T. parvidentata Perkins, 1981 (SANTI \& TAVARES, 2009), T. taeniaformis (Haswell, 1886) (DUARTE \& NALESSO,1996) e $T$. zebra (Grube, 1860) (FUKUDA, 2010). Possue espécies de fácil caracterização dentro do gênero pelo número de artículos de seus apêndices, corpo achatado e pigmentação característica.

\section{Trypanosyllis zebra (Grube, 1860)}

Fig. 37

Trypanosyllis zebra NOGUEIRA, 2000: 91-92, fig. 22A-F; NOGUEIRA \& FUKUDA, 2008: 914-919, fig. 1; FUKUDA, 2010: 317-320, fig. 86.

Material analisado: São Sebastião - Praia Grande, em Caulerpa lentilifera: 1 esp., 13.Dez.2015. Coletado na zona entremarés. 
Descrição: animal de tamanho corpóreo médio a grande, com corpo dorsoventralmente achatado, com pigmentação escura no dorso, castanha a avermelhada, apresentando 2 linhas transversais no dorso de cada setígero e inclusões de mesma coloração nos apêndices. Corpo com 19,375 mm de comprimento, com 130 setígeros e $0,875 \mathrm{~mm}$ de largura. Prostômio ovalado, levemente bilobado, com 2 pares de olhos em trapézio. Palpos reniformes, distalmente arredondados, completamente separados. Antena mediana ligeiramente maior do que as laterais, com 21 artículos, antenas laterais com 18 artículos, todas inseridas na margem anterior do prostômio. Peristômio menor do que os segmentos anteriores, cirros peristomiais dorsais do mesmo comprimento da antena mediana, 21 artículos, cirros peristomiais ventrais com 14 artículos, menores do que as antenas laterais. Antenas, cirros peristomiais, dorsais ao longo do corpo e anais moniliformes; cirros dorsais do primeiro setígero maiores do que as antenas, com 33 artículos, cirros dorsais seguintes com 30 artículos, os da região mediana com 13 artículos e os posteriores, com 14; cirros dorsais com conspícua alternância no comprimento ao longo de todo o corpo; cirros ventrais digitiformes, pouco mais curtos do que os lóbulos parapodiais. Parapódios com 3 acículas cada, na região anterior, 2 acículas por parapódio na região mediana e 1 na posterior, praticamente retas, ligeiramente inclinadas subdistalmente, com ponta arredondada (Fig. 37D-E). Cerdas falcígeras com lâminas bidentadas, com dentes de aproximadamente mesmo tamanho, e conspícua espinulação nas lâminas e nas hastes (Fig. 37A-B), lâminas das cerdas da região anterior medindo 47,5-35 $\mu \mathrm{m}, 35-30 \mu \mathrm{m}$ na região mediana e $30-17,5 \mu \mathrm{m}$ na posterior. Parapódios com 8 cerdas falcígeras cada na região anterior, 7 na mediana e 5 na posterior; cerdas simples dorsais e ventrais bidentadas, presentes na região posterior (Fig. 37C). Faringe ocupando 10 segmentos, com trépano formado por 10 dentes pontiagudos, podendo apresentar também dente central cônico, localizado na porção anterior, mais próximo da margem. Proventrículo estendendo-se por 10 segmentos, com 38 
feixes musculares.

Discussão: das espécies registradas no Brasil, a única cujos membros poderiam ser confundidos com exemplares de T. zebra é T. aurantiacus Nogueira \& Fukuda, 2008. Membros destas espécies diferem, todavia, porque exemplares de T. zebra são maiores, com pigmentação característica zebrada, apresentam número maior de artículos nos apêndices e têm cerdas falcígeras com lâminas conspicuamente bidentadas, enquanto exemplares de $T$. aurantiacus não têm padrões de pigmentação, exceto pelo tegumento ser cor de laranja e as lâminas das falcígeras são sub-bidentadas, com dente subdistal assemelhando-se a uma espinha (NOGUEIRA \& FUKUDA, 2008).

Localidade-tipo: França (Mar Mediterrâneo).

Distribuição: Espécie cosmopolita, com vários registros no Mar Mediterrâneo (mares Adriático e Egeu), no Caribe (Oceano Atlântico), e no litoral da Oceania (oceanos Índico e Pacífico), África (oceanos Índico e Atlântico), Europa (Oceano Atlântico) e Américas (oceanos Pacífico e Atlântico).

Fig. 35 -. Trypanosyllis zebra. A, cerdas falcígeras, região anterior; $\mathbf{B}$, cerdas falcígeras, região posterior; $\mathbf{C}$, cerda simples dorsal; $\mathbf{D}$, acículas, região anterior; $\mathbf{E}$, acícula, região posterior. Barra de escala: A-E $=20 \mu \mathrm{m}$.

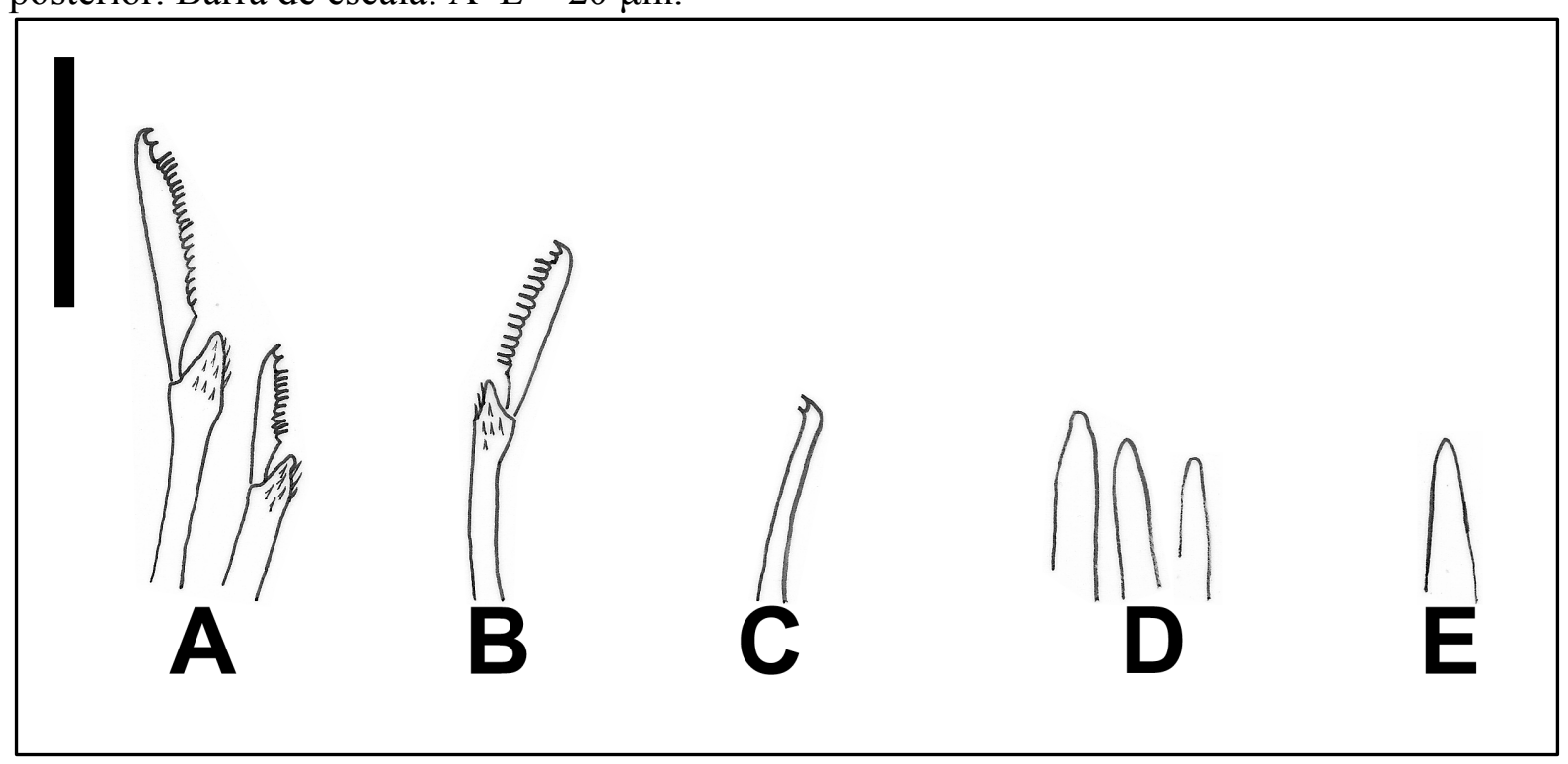

Fonte: Desenho de autoria própria. 


\section{V - CONSIDERAÇÕES FINAIS}

As constatações que serão feitas nesta secção são dados que chamaram a atenção durante o processo de análise do material e, portanto, demandam um estudo mais aprofundado, para que seja possível tomar conclusões a respeito das mesmas.

Algumas espécies apresentaram discrepâncias com descrições anteriores das mesmas em relação às medidas corpóreas dos indivíduos, são estas: Exogone africana, E. breviantennata, E. lourei, Haplosyllis rosenalessoae, Megasyllis procera, Odontosyllis cf. fulgurans e O. guillermoi.

Os membros encontrados de E. africana têm aproximadamente o mesmo tamanho daqueles encontrados nos demais estudos, contudo as lâminas das pseudoespinígeras medianas são menores, pois os exemplares encontrados anteriormente apresentavam lâminas com mais de $40 \mu \mathrm{m}$ de comprimento, enquanto os examinados neste estudo, possuem lâminas com, no máximo, 37,5 $\mu \mathrm{m}$. Estruturas relacionadas a obtenção de alimento também apresentaram algumas diferenças, entre os diferentes exemplares; por exemplo, estudos anteriores apontaram que a faringe se estendia por 3 segmentos, enquanto agora foram observados animais om faringe ocupando 4-6 segmentos; o proventrículo, de acordo com estudos anteriores, apresenta cerca de 21 feixes musculares (FUKUDA, 2010), enquanto nos animais do fital foi verificado que ele tem 27-26 feixes.

Os exemplares de $E$, breviantennata examinados neste estudo são menores e apresentam menos setígeros, em comparação com exemplares de outras localidades e ambientes. O maior indivíduo neste estudo tem 3,625 mm e 30 setígeros, enquanto a média apresentada pela espécie nos demais estudos é de $6 \mathrm{~mm}$ de comprimento e 43 setígeros (NOGUEIRA, 2000; NOGUEIRA et al., 2004; FUKUDA, 2010). 
Os exemplares de E. lourei do fital têm lâminas das pseudoespinígeras medianas menores, apresentando, em média, $30 \mu \mathrm{m}$ de comprimento, enquanto a média da espécie é aproximadamente $48 \mu \mathrm{m}$. Por outro lado, os animais do fital são maiores do que aqueles coletados previamente, alcançando $5,625 \mathrm{~mm}$ de comprimento e $0,275 \mathrm{~mm}$ de largura, enquanto o maior indivíduo previamente analisado tem $4 \mathrm{~mm}$ de comprimento e 0,17 $\mathrm{mm}$ de largura (FUKUDA, 2010).

Os espécimes de $H$, rosenalessoae são mais robustos e têm faringe mais longa do que o conhecido anteriormente para esta espécie, com animais de até $0,625 \mathrm{~mm}$ de largura e faringe estendendo-se até 8 setígeros, enquanto os exemplares previamente analisados apresentaram a metade da largura, $0,3 \mathrm{~mm}, \mathrm{e}$ faringe estendendo-se por, no máximo, 6 setígeros (PARESQUE \& NOGUEIRA, 2014).

Os exemplares examinados de $M$. procera do fital apresentaram significativas diferenças, em relação àqueles examinados em outros estudos. Os animais do fital são muito maiores, mais robustos, com faringe mais longa e proventrículo com mais fileiras musculares. O maior exemplar do fital mede $18,875 \mathrm{~mm}$, por $0,625 \mathrm{~mm}$ de largura na região mais robusta e $0,375 \mathrm{~mm}$ de largura na região mais fina, com 92 setígeros, faringe estendendo-se por 5 segmentos e o proventrículo, por 6 , com 32 feixes musculares, enquanto o maior espécime brasileiro conhecido previamente mede $10 \mathrm{~mm}$, por $0,3 \mathrm{~mm}$ de largura (não foi feita a medição na região mais fina), com 72 setígeros, com faringe e o proventrículo estendendo-se, cada um, por 3 segmentos, o proventrículo com 27 feixes musculares (PARESQUE, 2014).

Os indivíduos de Odontosyllis cf. fulgurans do fital se assemelham muito aos espécimes já descritos para a costa brasileira na maioria dos caracteres, contudo também são maiores, alcançando 78 setígeros e $6,5 \mathrm{~mm}$ de comprimento, enquanto o maior exemplar brasileiro conhecido previamente tem 50 setígeros e $5 \mathrm{~mm}$ de comprimento (FUKUDA, 2010) 
Finalmente, os espécimes de Odontosyllis guillermoi do fital são menores do que aqueles coletados em estudos anteriores, o maior com 4,375 $\mathrm{mm}$ de comprimento e $0,5 \mathrm{~mm}$ de largura, enquanto são conhecidos exemplares desta espécie com $19 \mathrm{~mm}$ de comprimento e 1,5 mm de largura. Também é notória a diferença no comprimento da faringe dos animais, os do fital com faringe estendendo-se por até quase 8 segmentos, enquanto nos demais exemplares conhecidos desta espécie ela se estende por apenas 3 setígeros (FUKUDA \& NOGUEIRA, 2006; FUKUDA, 2010).

Foram observados também alguns padrões relacionados às algas nas quais os animais foram encontrados, a época do ano em que esse fital foi coletado (verão x inverno) e às localidades das coletas em si.

Em relação às localidades, foi observado que algumas praias apresentavam sazonalidade na presença de algas. Por exemplo, na Praia de São Francisco no verão e na Praia da Baleia no inverno, não foi possível localizar nenhuma quantidade significativa de fital para análise; enquanto na Praia Grande, durante o inverno, não foi possível localizar nenhuma alga da espécie Hypnea musciform. 
Tabela 1 - Distribuição de espécimes por localidade, fital e época do ano.

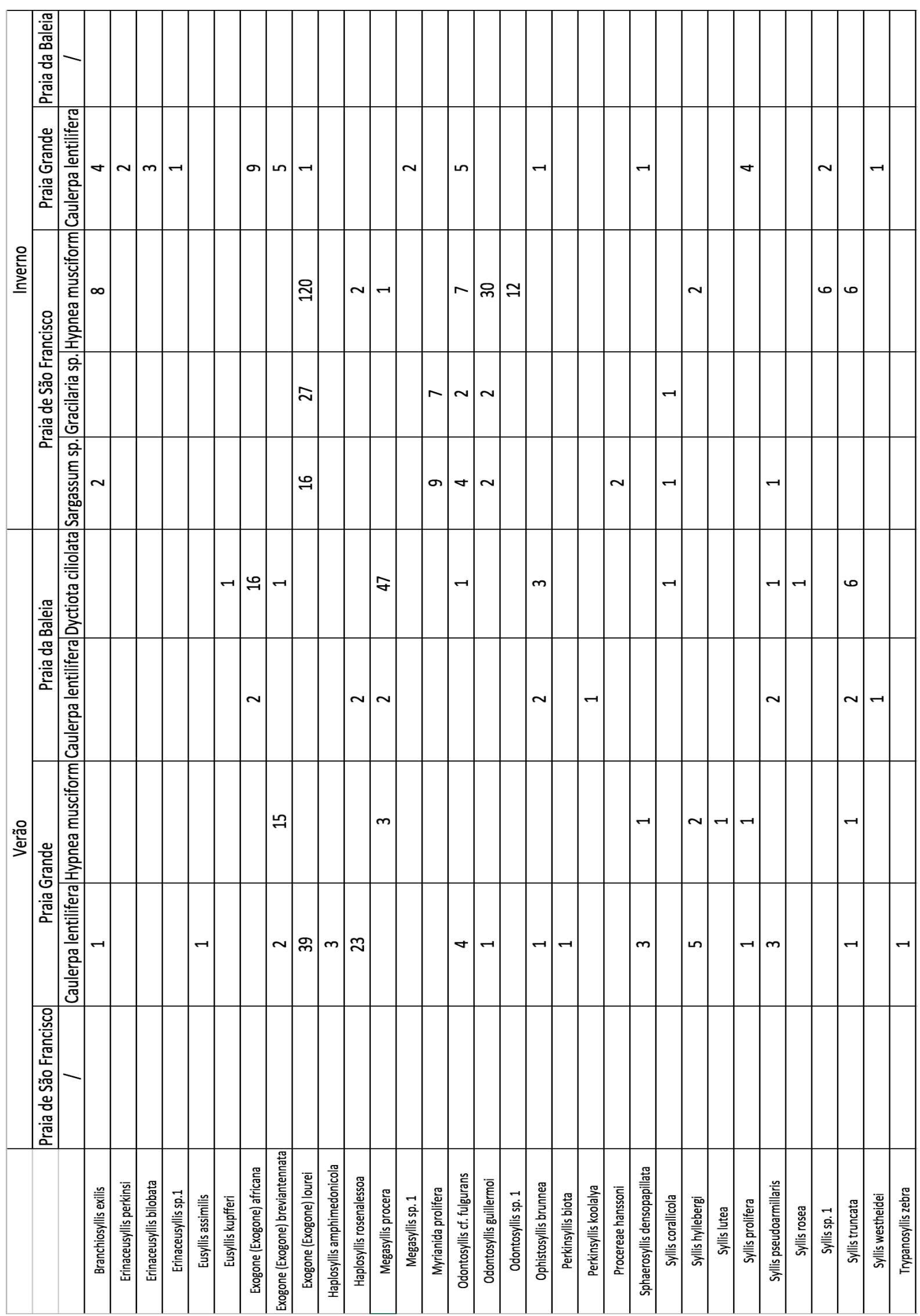

Fonte: Tabela de autoria própria. 


\section{REFERÊNCIAS}

- Aguado, M.T., NYGREN, A. \& SIDDALL, M.E. 2007. Phylogeny of Syllidae (Polychaeta) based on combined molecular analysis of nuclear and mitochondrial genes. Cladistics, 23: 552-564.

- $\quad$ AguAdo, M.T. \& SAN MARTíN, G. 2009. Phylogeny of Syllidae (Polychaeta) based on morphological data. Zoologica Scripta, 38 (4): 379-402.

- $\quad$ AgUAdo, M.T., SAN MARTíN, G. e SIDDALL, M.E. 2012. Systematics and evolution of syllids (Annelida, Syllidae). Cladistics, 28 (3): 234-250.

- $\quad$ AMARAL, A.C.Z., NALLIN, S.A.H., STEINER, T.M., FORRONI, T.O. e GOMES-FILHO, D. 2010. Catálogo das espécies de Annelida Polychaeta do Brasil. Disponível em: http://www.ib.unicamp.br/projbiota/bentos_marinho/prod_cien/texto_poli.pdf (acessado em 20 Abril 2017)

- AUdOUIN, J.V. \& MILNE-EDWARDS, H. 1833. Classification des Annélides et description de celles qui habitent les côtes de la France. Annales des Sciences Naturelles, 28: 187- 247; 29: 195-269.

- $\quad$ BERKELEY, E. \& BERKELEY, C. 1938. Notes on polychaeta from the coaste of western Canada. 2. Syllidae. Annals and Magazine of Natural History, London, series 11, 1: 33- 49.

- $\quad$ BICKFORD, D., LOHMAN, D. J., SODHI, N. S., NG, P. K. L., MEIER, R., WINKER, K., INGRAM, K. K. e DAS, I. 2007. Cryptic species as a window on diversity and conservation. Trends in Ecology and Evolution 22: 148-155.

- $\quad$ BRUSCA, R.C., MOORE, W. \& SHUSTER, S.M. 2016. Invertebrates, $3^{\text {rd }}$ ed. Sinauer Associates, Sunderland, Massachusetts.

- CLAPARÈDE, E. 1863. Beobachtungen über Anatomie und Entwicklungsgeschichte wirbelloser Thiere an der Küste von Normandie angestellt. 1-120. W. Engelmann. Leipzig. 47 p.

- ClAPARÈDE, E. 1864. Glanures zootomiques parmi les Annélides de Port-Vendres (Pyrenés Orientales). Mémoires de la Société de Physique et Sciences Naturelles de Genève, 17 (2), 463-600.

- $\quad$ DUARTE, L.F.L. \& NALESSO, R.C. 1996. The sponje Zygomycale parishii (Bowerbank) and its endobiotic fauna. Estuarine, Coastal and Shelf Science, 42: 139-151.

- $\quad$ EHLERS, E. 1864. Die Borstenwürmer (Annelida Chaetopoda) nach systematischen und anatomischen Untersuchungen dargestellt. Volume 1. 1-268. W. Engelmann. Leipzig., 256p. 
- $\quad$ EHLERS, E. (1887). Reports on the results of dredging, under the direction of L. F. Pourtalès, during the years 1868-1870, and of Alexander Agassiz, in the Gulf of Mexico (1877-78), and in the Caribbean Sea (1878-79), in the U.S. Coast Survey steamer "Blake", Lieut-Com. C. D. Sigsbee, U.S.N. and Commander J. R. Bartlett, U.S.N., commanding. XXXI. Report on the Annelids. Memoirs of the Museum of Comparative Zoology at Harvard College. 15: vi \& 335 p.

- $\quad$ FAUCHAlD, K. and ROUSE, G. (1997), Polychaete systematics: Past and present. Zoologica Scripta, 26: 71-138. doi:10.1111/j.1463-6409.1997.tb00411.x

- $\quad$ FUKUDA, M.V. 2010. Contribuição ao conhecimento taxonômico dos silídeos (Polychaeta: Syllidae) da região sudeste-sul do Brasil. 340p.

- FUKUDA, M.V. \& NOGUEIRA, J.M.M. 2006. A new species of Odontosyllis Claparède, 1863 (Polychaeta: Syllidae: Eusyllinae), and description of Brazilian material of Odontosyllis cf. fulgurans (Audouin \& Milne Edwards, 1834). Zoological Studies, 45(2): 223-233.

- FUKUDA, M.V. \& NOGUEIRA, J.M.M. 2013. First occurrence of Perkinsyllis San Martín, López \& Aguado, 2009 (Polychaeta: Syllidae) in Brazil, with descriptions of two new species. Marine Biology Research, 9:10, 972-989.

- GRAVIER, C. 1900. Contribution à l'étude des Annélides Polychètes de la Mer Rouge. Nouvelles Archives du Muséum d'Histoire Naturelle, Série 4, 2 (2): 137-282.

- GRUBE, A.E. 1850. Die Familien der Anneliden. Archiv für Naturgeschichte, 16: 249-364

- GRUBE, A.E. 1860. Beschreibung neuer oder wenig bekannter Anneliden. Archiv für Naturgeschichte, 26: 71-118.

- HAMOND, R. 1969a. Intergradation in Norfolk waters between some species of Autolytus (Polychaeta, Syllidae). Cahiers de Biologie marine, 10, 289-300.

- HARTMAN, O. 1965. Deep-water benthic polychaetous annelids off New England to Bermuda and other North Atlantic areas. Occasional Papers of the Allan Hancock Foundation, 28: 1-378.

- $\quad$ HARTMANN-SCHRÖDER, G. 1959. Zur Okologie der polychaeten des mangrove-esterogebiets von El Salvador. Beitrage zur Neotropical Fauna 1: 70-183.

- HARTMANN-SCHRÖDER, G. 1960. Polychaeten aus dem Rotem Meer. Kieler Meeresforschungen, 16: 69-125.

- HARTMANN-SCHRÖDER, G. 1974. Zur Kenntnis des Sublitorals der Afrikanischen Zwischen Angola und Kap de Guten Hoffnung und der Afrikanischen Ostküste von Südafrika und Mocambique unter Besonder Berücksichtigung der Polychaeten und Ostracoden. Teil II 
Die Polycheten des Untersuchungsgebietes. Mitteilungen aus dem Hamburgischen Zoologischen Museum und Institut, 69: 95-228.

- HARTMANN-SCHRÖDER, G. 1979. Die Polychaeten der tropischen Nordwestküste Australiens (zwischen Derby im Norden und Port Hedland im Süden). In: HartmannSchröder, G. \& Hartmann, G. Zur Kenntnis des Eulitorals der australischen Küsten unter besonderer Berücksichtigung der Polychaeten und Ostracoden. T eil 2. Mitteilungen aus dem Hamburgischen Zoologischen Museum und Institut, 76: 75-218.

- HASWELL, W.A. 1920. Australian Syllidae, Eusyllidae and Autolytidae. Proceedings of the Linnean Society of New South Wales, 45: 90-112.

- $\quad$ HUTCHINGS, P. 1998. Biodiversity and functioning of polychaetes in benthic sediments. Biodiv. Conserv. 7: 1133-1145.

- INTERNATIONAL COMISSION ON ZOOLOGICAL NOMENCLATURE. 1999. International Code of Zoological Nomenclature. The International Trust for Zoological Nomenclature, Londres.

- KNOWLTON, N. 1993. Sibling species in the sea. The Annual Review of Ecology and Systematics, 24: 189-216.

- KNOWLTON, N. 2000. Molecular genetic analyses of species boundaries in the sea. Hydrobiologia, 420: 73-90.

- $\quad$ KROHN, A. 1852. Ueber die Erscheiungen bei der Fortpflanzung von Syllis prolifera und Autolytus prolifer. Archiv für Naturgeschichte, 18 (1): 66-76.

- LANGERHANS, P. 1879. Die Würmfauna von Madeira. Zeitschrift für Wissenschaftliche Zoologie, 33: 513-592.

- $\quad$ LICHER, F. 1999. Revision der Gattung Typosyllis Langerhans, 1879 (Polychaeta: Syllidae). Morphologie, Taxonomie und Phylogenie. Abhandlungen der Senckenbergischen Naturforschenden Gesellschaft, 551: 1-336.

- MACHADO, M.C.S. 1986. Sistema Planctônico da Região do Emissário Submarino de Esgotos de Ipanema, Rio de Janeiro - RJ - Populações Zooplanctônicas: Annelida Polychaeta. Dissertação de Mestrado, Universidade Federal do Rio de Janeiro, 256 p.

- MALAQUIN, A. 1893. Recherches sur les syllidiens. Morphologie, Anatomie, Reproduction, Développement. Mémoires de la Société des Sciences, de l'Agriculture et des Arts de Lille, $4^{\text {ème }}$ série, 18: 1-477. 
- MAlmGREN, A.J. 1867. Annulata Polychaeta Spetsbergiæ, Grœnlandiæ, Islandiæ et Scandinaviæ. Hactenus Cognita. Ex Officina Frenckelliana, Helsingforslæ. 127 pp. \& XIV plates.

- $\quad$ MARENZELlER, E. V. 1875. Zur Kenntniss der adriatischen Anneliden. Zweiter Beitrag. (Polynoinen, Hesioneen, Syllideen). Sitzungsberichte der Kaiserlichen Akademie der Wissenschaften, Wien, Mathematisch-Naturwissenschaftliche Classe. 72(1): 129-171, plates IIV.

- $\quad$ MARTIN, D. 1987. The polychaetous annelids community from coraline algae aggreggates of the Catalan littoral shores: species characterisation [In Spanish]. Publ. Dept. Zool. Barcelona XII: $45-54$.

- $\quad$ MARTIN, D., BRITAYEV, T.A. 1998. Symbiotic polychaetes: Review of known species. Oceanogr. Mar. Biol. Ann. Rev. 36: 217-340.

- MASUNARI, S. 1987. Ecologia das comunidades fitais. In: Simpósio de ecossistemas da costa sul e sudeste brasileira, anais. Águas de Lindóia, Academia Brasileira de Ciências 1: 199-253.

- $\quad$ MASUNARI, S., FORNERIS, L. 1981. O ecossistema fital - uma revisão. In: Seminários de biologia marinha, resumo. Rio de Janeiro, Academia Brasileira de Ciências 1: 149-172.

- $\quad$ MILNE-EDWARDS, M. 1845. Observations sur le développement des annélides. Annales des Sciences Naturelles, Paris, 3: 145-182.

- $\quad$ MÜLleR O. F. 1788. Zoologia Danica seu animalium Daniae et Norvegiae rariorum ac minus notorum descriptiones et historia. Volumen primum: pp. [1-5], 1-46, pls. 121-160. Havniae [Copenhague], N. Möller.

- NASCIMENTO, E. F. I., ROSSO, S. 2007. Fauna associada às macroalgas marinhas bentônicas (Rhodophyta e Phaeophyta) da região de São Sebastião, São Paulo. Brazilian Journal of Ecology, 1-2: 38-51.

- $\quad$ NYGREN, A. 2004. Revision of Autolytinae (Syllidae: Polychaeta). Zootaxa 680: 1-314.

- NYGREN, A. 2013. Cryptic polychaete diversity: a review. Zoologica Scripta, 00: 000-000.

- NOGUEIRA, J. M. M. 2000. Anelídeos poliquetas associados ao coral Mussismilia hispida (Verrill, 1868) em ilhas do litoral do Estado de São Paulo. Phyllodocida, Amphinomida, Eunicida, Spionida, Terebellida e Sabellida. PhD thesis, Universidade de São Paulo, São Paulo, Brazil. 295p.

- $\quad$ NOGUEIRA, J.M.M. 2006. Família Syllidae. In: Amaral, A.C.Z., Rizzo, A.E. \& Arruda, E.P. (eds.), Manual de Identificação dos Invertebrados Marinhos da Região Sudeste- Sul do 
Brasil, volume 1. Edusp, São Paulo. pp. 134-164.

- $\quad$ NOGUEIRA, J.M.M. \& AMARAL, A.C.Z. 1997. Anelídeos poliquetas associados ao coral Mussismilia hispida (Verrill) na Laje de Santos (SP-Brasil) - Análise Preliminar. VII Congresso Latino-americano sobre Ciências do Mar, Resumos expandidos, 7(2): 219-220.

- $\quad$ NOGUEIRA, J.M.M. \& SAN MARTÍN, G. 2002. Species of Syllis Savigny in Lamarck, 1818 (Polychaeta: Syllidae) living in corals in the state of São Paulo, southeastern Brazil. Beaufortia, 52 (7): 57-93.

- $\quad$ NOGUEIRA, J.M.M., SAN MARTíN, G. \& FUKUDA, M.V. 2004. On some exogonines (Polychaeta, Syllidae) from the northern coast of the State of São Paulo, southeastern Brazil Results of BIOTA/FAPESP/Bentos Marinho Project. Meiofauna Marina 13: 45- 78.

- NOGUEIRA, J.M.M. \& FUKUDA, M.V. 2008. A new species of Trypanosyllis Claparède, 1864 (Polychaeta: Syllidae) from Brazil, with a redescription of Brazilian material of Trypanosyllis zebra. Journal of the Marine Biological Association of the United Kingdom, 88 (5): 913-924.

- ÖRSTED, A. S. 1843. Annulatorum danicorum conspectus. Volume Fasc. 1 Maricolae (Quæstio ab universitate Hafniensi ad solvendum proposita et proemio ornata). 1-52. Librariae Wahlianae. Hafniae (Copenhagen).

- $\quad$ PARESQUE, K 2014. Diversidade de Syllidae (Annelida, Polychaeta) em Substratos Consolidados nos Estados de Pernambuco e Paraíba. 443 p.

- $\quad$ PARESQUE, K.; NOGUEIRA, J.M.M. \& FUKUDA, M.V. 2012a. O gênero Proceraea (Polychaeta, Syllidae) no litoral do Estado da Paraíba. $3^{\circ}$ Simposio Latino-Americano de Polychaeta, p.41.

- $\quad$ PARESQUE, K., FUKUDA, M.V., NOGUEIRA, J.M.M. 2014. The genus Exogone (Polychaeta: Syllidae) from the Brazilian coast, with the description of a new species. Zootaxa, 3790 (4): 501-533.

- $\quad$ PARESQUE, K. \& NOGUEIRA, J. M. M. 2014. The genus Haplosyllis Langerhans, 1879 (Polychaeta: Syllidae) from northeastern Brazil, with descriptions of two new species. Marine Biology Research, 10, No. 6, 554-576

- $\quad$ PERKINS, T. 1981. Syllidae (Polychaeta), principally from Florida, with descriptions of a new genus and twenty-one new species. Proceedings of the Biological Society of Washington, 93 (4): 1080-1172.

- $\quad$ RIOJA, E. 1925. Anélidos Poliquetos de San Vicente de la Barquera (Cantábrico). Trabajos del Museo Nacional de Ciencias Naturales. Serie Zoológica, 53: 5-62. 
- RISER, N.W. 1991. An evaluation of taxonomic characters in the genus Sphaerosyllis (Polychaeta: Syllidae). Ophelia, supplement 5: 209-217.

- $\quad$ ROUSE, G. W. and FAUCHALD, K. (1997), Cladistics and polychaetes. Zoologica Scripta, 26: 139-204. doi:10.1111/j.1463-6409.1997.tb00412.x

- $\quad$ ROUSE, G.W. \& PLEIJEL, F. 2001. Polychaetes. Oxford: Oxford University Press. 354 p.

- RUSSELL, D.E. 1989. Three new species of Sphaerosyllis (Polychaeta, Syllidae) from mangrove habitats in Belize. Zoologica Scripta, 18 (3): 375-380.

- $\quad$ SÁEZ, A. G. \& LOZANO, E. 2005. Body doubles. Nature 433: 111.

- SAN MARTíN, G. 1984a. Estudio biogeográfico, faunístico y sistemático de los Poliquetos de la família Sílidos (Syllidae: Polychaeta) en Baleares. Publicaciones de la Universidad Complutense de Madrid, 187, Madri. 581p.

- $\quad$ SAN MARTín, G. 2003. Annelida Polychaeta II: Syllidae. In Ramos M.A., Alba Tercedor J., Bellés i Ros X., Gosálbez i Noguera J., Guerra Sierra A., Macpherson Mayol E., Martin Piera F., Serrano Marino J. and Templado González J. (eds) Fauna Ibérica, Volume 21. Madrid: Museo Nacional de Ciências Naturales, CSIC. 554 p.

- $\quad$ SAN MARTÍN, G. 2004. Deep sea Syllidae from the Pacific Ocean, collected during cruises with the RV Sonne (Annelida, Polychaeta, Syllidae). Senckenbergiana biologica, 84(1/2): 1325.

- SAN MARTÍN, G. 2005. Exogoninae (Polychaeta, Syllidae) from Australia with the description of a new genus and twenty-two new species. Records of the Australian Museum, 57: 39-152.

- SAN MARTÍN, G. \& HUTCHINGS, P. 2006. Eusyllinae (Polychaeta: Syllidae) from Australia with the description of a new genus and fifteen new species. Records of the Australian Museum, 58: 257-370.

- SAN MARtín, G., HUTChingS, P., AGUAdO, M.T. 2008a. Syllinae (Polychaeta, Syllidae) from Australia. Part. 1. Genera Branchiosyllis, Eurysyllis, Karroonsyllis, Parasphaerosyllis, Plakosyllis, Rhopalosyllis, Tetrapalpia n.gen., and Xenosyllis. Records of the Australian Museum, 60(2): 119-160.

- $\quad$ SAN MARtín, G., HUTChingS, P., AGUAdO, M.T. 2008b. Syllinae (Polychaeta, Syllidae) from Australia. Part. 2. Genera Inermosyllis, Megasyllis n. gen., Opisthosyllis, and Trypanosyllis. Zootaxa, 1840: 1-53. 
- $\quad$ SAN MARTÍN, G., HUTChINGS, P., AGUADO, M.T. 2010. Syllinae (Polychaeta, Syllidae) from Australia. Part. 3. Genera Alcyonosyllis, Parahaplosyllis, and Trypanosyllis (Trypanobia). Zootaxa, 2493: 35-48.

- $\quad$ SAN MARTíN, G., LÓPEZ, E. \& AGUADO, M.T. 2009. Revision of the genus Pionosyllis (Polychaeta: Syllidae: Eusyllinae), with a cladistic analysis, and the description of five new genera and two new species. Journal of the Marine Biological Association of the United Kingdom, 89 (7): 1455-1498.

- $\quad$ SAN MARTíN, G., AGUAdo, M.T., ÁlVAREZ-CAMPOS, P. 2014. Revision of the genus Megasyllis (Annelida, Syllidae) with the description of four new species. Journal of the Marine Biological Association of the United Kingdom, 94 (2): 331-351.

- $\quad$ SCHIEDGES, K.L. 1979a. Reproductive biology and ontogenesis in the polychaete genus Autolytus (Annelida: Syllidae): observations on laboratory-cultured individuals. Marine Biology, 54, 239-250.

- SCHIEDGES, K.L. 1979b. Field and laboratory investigations of factors controlling schizogamous reproduction in the polychaete, Autolytus. International Journal of Invertebrate Reproduction, 1, 359-370.

- $\quad$ SCHIEDGES, K.L. 1980. Morphological and systematic studies of an Autolytus population (Polychaeta, Syllidae, Autolytinae) from the Oosterschelde estuary. Netherlands Journal of Sea Research, 14, 208-219.

- $\quad$ SNelgrove, P.V.R., BlACKBURN, T.H., HUTCHINGS, P.A., ALONGI, D.M., GRASSLE, J.F., HUMMEL, H., KING, G., KOIKE, I., LAMBSHEAD, P.J.D., RAMSING, N.B. \& SOLIS-WEISS, V. 1997. The importance of marine sediment biodiversity in ecosystem processes. Ambio, 26 (8): 578-583.

- TAVARES, M. \& SANTI, L. 2009. Polychaete assemblage of an impacted estuary, Guanabara Bay, Rio de Janeiro, Brazil. Brazilian Journal of Oceanography (Impresso), 57: 287-303.

- TEMPERINI, M.T. 1981. Sistemática e Distribuição dos Poliquetos Errantes da Plataforma Continental Brasileira entre as Latitudes de $23^{\mathbf{0}} 05$ 'S e 30 ${ }^{\mathbf{0}} 00$ 'S. Dissertação de Mestrado, Instituto Oceanográfico, Universidade de São Paulo, 89 p

- VERrill, A. E. 1900. Additions to the Turbellaria, Nemertina and Annelida of the Bermudas with revisions of some New England genera and species. Transactions of the Connecticut Academy of Arts and Sciences, 10: 595-671. 